\title{
Trade and the Separation of Powers
}

\author{
Timothy Meyer* \& Ganesh Sitaraman**
}

There are two paradigms through which to view trade law and policy within the American constitutional system. One paradigm sees trade law and policy as quintessentially about domestic economic policy. Institutionally, under the domestic economics paradigm, trade law falls within the province of Congress, which has legion Article I powers over commercial matters. The second paradigm sees trade law as fundamentally about America's relationship with foreign countries. Institutionally, under the foreign affairs paradigm, trade law is the province of the President, who speaks for the United States in foreign affairs. While both paradigms have operated throughout American history, the domestic economics paradigm dominated in the nineteenth century, and the foreign affairs paradigm from the mid-twentieth century.

Since the end of the Cold War, however, trade law and policy have become increasingly divisive and contentious. Trade law and policy entered a new era of liberalization, characterized by international organizations (like the WTO) and a shift to mini-lateral free trade agreements. By 2016, backlash was in full force, with candidates Donald Trump, Bernie Sanders, and Hillary Clinton all coming out against the Trans-Pacific Partnership (TPP). Since taking office, President Trump has instituted high tariffs on solar panels, threatened to withdraw from NAFTA, and sparked concern about a trade war with China.

DOI: https://doi.org/10.15779/Z386H4CQ95

Copyright (C) 2019 California Law Review, Inc. California Law Review, Inc. (CLR) is a California nonprofit corporation. CLR and the authors are solely responsible for the content of their publications.

* FedEx Research Professor, Vanderbilt University Law School.

** Professor of Law, Vanderbilt University Law School. The authors would like to thank Kristen Eichensehr, Jean Galbraith, David Grewal, Duncan Hollis, Jide Nzelibe, Todd Tucker, Ingrid Wuerth, and participants in workshops at the University of California-Irvine, the University of Chicago, Drexel University, and the Joint North American Conference on International Economic Law at McGill University. We also thank Allen Perry and Paulson Varghese for excellent research assistance. 
This Article makes three contributions. First, we argue that the current discontent over trade is not just a matter of the distribution of economic gains and losses but a matter of the distribution of constitutional powers. We provide a thorough descriptive account of the two paradigms for trade within our constitutional system and show that trade has migrated from a domestic to a foreign affairs matterand ultimately that it has become unhooked even from specific foreign affairs objectives. As trade drifted further away from the balance struck by our separation of powers and became increasingly rooted in the presidency, agreements liberalizing trade rules became more viable - but at the cost of the political sustainability that comes with greater congressional involvement.

Second, we make a normative case for rebalancing trade within the constitutional structure. We argue that trade shares few similarities with other foreign affairs and national security areas in which the President is seen to have a functional advantage, and, perhaps surprisingly given the conventional wisdom, that the parochial interests of Congress present strong benefits to trade policymaking that are widely undervalued.

Finally, we apply this rebalanced framework for trade law and policy to a variety of contemporary debates, including the role of fasttrack authority in negotiating and approving trade agreements, the President's power to declare trade wars, the scope of the President's authority to withdraw from trade agreements, the use of unorthodox international agreements in the commercial context, and the increasing conflict between trade agreements and state and local authority, which we term "trade federalism."

Introduction 585

I. Trade and the Separation of Powers: Two Paradigms

A. Trade as Domestic Economics: The Founding Through the Long Nineteenth Century.

B. Trade as Foreign Affairs: The Rise and Rise of Presidential

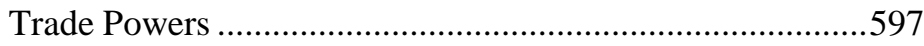

C. The Liberalization Era and the Separation of Powers..........612

1. Institution Building at the End of the Cold War............613

2. The Turn Toward Free Trade Agreements (FTAs)........617

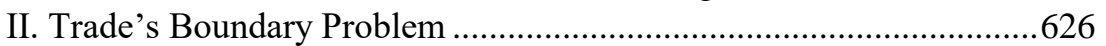

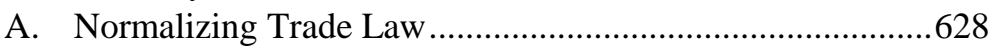

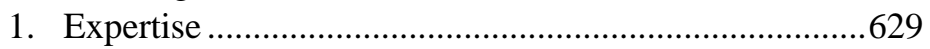

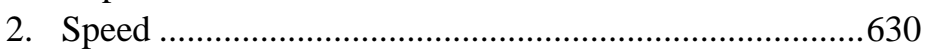

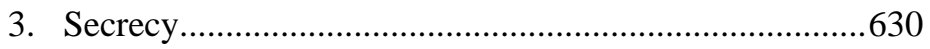

B. The Benefits of a Parochial Congress …………....................632

C. The Captured Trade Presidency..... 638 
III. Implications and Extensions 641

A. Fast Track and Congressional Oversight ............................642

B. The Power to Declare Trade Wars ..........................................644

C. Withdrawing from Trade Agreements .................................652

1. Restricting Presidential Power to Withdraw...................654

2. Implicit and Explicit Authorizations to Withdraw.........655

3. No Authorization to Withdraw 659

D. Unorthodox International Lawmaking: Soft Law and

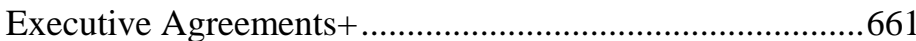

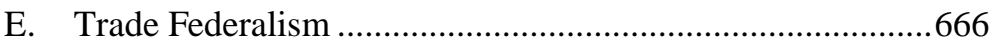

Conclusion

\section{INTRODUCTION}

There are two paradigms through which to view trade law and policy within the American constitutional system. One paradigm sees trade law and policy as quintessentially about domestic economic policy. Under this domestic economics paradigm, tariffs raise revenue to fund government programs, infrastructure, and social goods. Trade restrictions encourage the development of infant industries, protect developed industries, and ensure a robust industrial base, which is essential for homeland security and defense. Trade law can also guarantee a more egalitarian distribution of wealth and opportunities by safeguarding the wages and jobs of American workers. Institutionally, under the domestic economics paradigm, trade law falls within the province of Congress, which has legion Article I powers, including the powers to regulate foreign commerce, set tariffs and imposts, and originate revenue bills. Congressional authority is desirable because domestic economic policy is appropriately pursued through a participatory and representative process that includes interest group bargaining, logrolling, and attention to regional diversity.

The second paradigm sees trade law as fundamentally about America's relationship with foreign countries. Under the foreign affairs paradigm, tariff rates should be negotiated as part of agreements with foreign countries to achieve consensus on barriers to trade. Trade agreements are a tool of diplomacy and geopolitics: opening markets to countries that will side with democracy and human rights, asserting American leadership in setting the rules of the road for global commerce, and punishing those who violate international norms through sanctions. Trade law also seeks to help American businesses go abroad in search of new markets and new consumers, while providing American consumers with access to cheaper goods. Institutionally, under the foreign affairs paradigm, trade law is the province of the President, who speaks for the United States in foreign affairs, serves as commander in chief, and has the power under Article II to appoint and receive ambassadors and to negotiate and make treaties with foreign nations. Executive power is desirable because the President is best positioned to 
assess geopolitical conditions, negotiate with foreign countries, and represent the interests of the nation as a whole.

These two constitutional paradigms have coexisted throughout American history, fading in and out of view as foreign affairs or domestic economic issues were most salient. But by and large, the domestic economics paradigm defined trade law from the founding into the early twentieth century, with Congress in the driver's seat. Successive tariff acts advanced a variety of goals crucial to the success of the new nation: generating revenue to fund the government, developing the West through internal improvements, protecting burgeoning industries from foreign competition, and safeguarding the interests of laborers from low-wage foreign workers. Over time, however, the foreign affairs paradigm came to dominate, with the President wielding greater and greater power over trade policy. With American manufacturing leading the globe, World War II leaving foreign countries in ruins, and the contest between democracy and communism dividing the world, trade was increasingly seen as a matter of foreign relations.

Since the end of the Cold War, however, trade law and policy have become increasingly divisive and contentious. Trade law and policy entered a new era of liberalization, characterized by international organizations, like the World Trade Organization (WTO), and a shift to mini-lateral free trade agreements. But even as President Bill Clinton concluded agreements like the North American Free Trade Agreement (NAFTA) and negotiated China's entry into the WTO, antitrade advocates from Pat Buchanan to Ross Perot gained substantial followings. By the 2016 election, the political consensus over trade had broken down. Republican presidential nominee Donald Trump opposed the pending TransPacific Partnership (TPP), as did Democratic-Socialist Bernie Sanders and even Democratic presidential nominee Hillary Clinton, who announced her opposition to the trade agreement despite having supported it as Secretary of State. President Trump said that he would either renegotiate NAFTA or withdraw from the agreement, and on September 30, 2018, the Trump administration announced it had reached terms on a renegotiated NAFTA 2018 (known formally as the United States-Mexico-Canada Agreement, or USMCA). ${ }^{1}$ He has imposed tariffs as high as 30 percent on solar panels, ${ }^{2} 50$ percent on washing machines, ${ }^{3} 25$

1. Vicki Needham, Trump Says He Will Renegotiate or Withdraw from NAFTA, HILL (June 28, 2016), http://thehill.com/policy/finance/285189-trump-says-he-will-renegotiate-or-withdraw-fromnafta-without-changes [https://perma.cc/AD7H-FVLU]; Executive Office of the President, Joint Statement from United States Trade Representative Robert Lighthizer and Canadian Foreign Minister Chrystia Freedland, OFFICE OF THE U.S. TRADE REP. (Sept. 30, 2018), https://ustr.gov/about-us/policyoffices/press-office/press-releases/2018/september/joint-statement-united-states [https://perma.cc/64YX-5TLN].

2. Ana Swanson \& Brad Plumer, Trump Slaps Tariffs on Foreign Washing Machines and Solar Products, N.Y. TIMES (Jan. 22, 2018), https://www.nytimes.com/2018/01/22/business/trumptariffs-washing-machines-solar-panels.html [https://perma.cc/S78T-G5KA].

3. Id. 
percent on steel, and 10 percent on aluminum. ${ }^{4}$ Some commentators have concluded that the President has started a trade war with China. ${ }^{5}$

With the potential for significant changes in trade policy on the horizon, many are scrambling to understand the limits of the President's powers and the ability of Congress to block the President if, for instance, he tried to withdraw from NAFTA or the WTO. ${ }^{6}$ Perhaps paradoxically, President Trump relies on expansive presidential power derived from the foreign affairs paradigm, but he does so to advance domestic economic goals that would traditionally be within the scope of Congress's constitutional authority to make economic policy.

We make three contributions in this Article. First, we argue that the current discontent over trade is not just a matter of the distribution of economic gains and losses but a matter of the distribution of constitutional powers. We provide a descriptive account of the two paradigms of trade under the Constitution from the founding until the present. This account explains the two paradigms and shows that the domestic paradigm dominated in the long nineteenth century until it was supplanted in the mid-twentieth century by the foreign affairs paradigm and the rise of presidential trade powers. We show that one of the fundamental challenges for contemporary trade law and policy is that over the last few decades, trade has increasingly become unhooked from either the domestic economics paradigm or the foreign affairs paradigm. The rise of presidential trade powers has meant that in the short run, trade liberalization has proceeded expeditiously, but with little regard for either of these historic aims. And it has come at a long-term cost to the sustainability of trade policies within domestic politics. The causes of the current backlash over trade are, therefore, intimately tied to the distribution of constitutional powers and the statutory frameworks that implement those powers.

Second, we seek to make a normative case for rebalancing trade law away from the foreign affairs paradigm, which has all but drowned the domestic economics paradigm. We do not mean to suggest that trade should be seen as wholly domestic, subject only to the messy process of congressional horse-

4. Ana Swanson, Trump Administration Proposes Stiff Penalties on Steel and Aluminum Imports, N.Y. TIMES (Feb. 16, 2018), https://www.nytimes.com/2018/02/16/us/politics/trumpadministration-recommends-stiff-penalties-on-steel-and-aluminum-imports.html [https://perma.cc/QEM4-ZZPG]; Rachel Layne, President Trump's Steel and Aluminum Tariffs: Winners and Losers, CBS MONEYWATCH (May 31, 2018), https://www.cbsnews.com/news/presidenttrumps-steel-and-aluminum-tariffs-winners-and-losers [https://perma.cc/NE56-U352].

5. William Pesak, How Trump's Trade War is Driving China Nuts, POLITICO (Oct. 16, 2018), https://www.politico.com/magazine/story/2018/10/16/donald-trump-trade-war-china-221310 [https://perma.cc/V5CP-Q67B].

6. Luis Abad, How Much Power Does President Trump Actually Have Over Trade Deals?, FORBES (April 3, 2017), https://www.forbes.com/sites/kpmg/2017/04/03/how-much-power-doespresident-trump-actually-have-over-trade-deals/\#611e19737a62 [https://perma.cc/U38U-RZN5]; Bethany Allen-Ebrahimian, Can Congress Block Trump if He Pulls Out of NAFTA?, FOREIGN POLICY, (Oct. 17, 2017, http://foreignpolicy.com/2017/10/17/can-congress-block-trump-if-he-pulls-out-of-nafta [https://perma.cc/VDM3-EZFL]. 
trading. Rather, we argue that some of the justifications for expansive presidential power in this arena are inapplicable and others are far weaker than conventionally assumed. In this sense, we seek to "normalize" trade within the constitutional system, rather than seeing it as exceptional simply because it touches on foreign affairs. ${ }^{7}$ We argue that many of the features that supposedly differentiate foreign affairs from domestic affairs do not apply, or do not apply as strongly, in the case of trade. In addition, we question the oft-repeated claim that the "nationalist" president is better suited to making trade policy for the whole country because of the considerable benefits that come from Congress's parochial interests. At the same time, we show that the downsides of congressional capture by interest groups must be compared with the downsides of presidential capture - and that contrary to the "nationalist" story, the institutional design of the trade presidency heightens, rather than reduces, the risk of capture.

One of the implications of rebalancing trade in favor of the domestic economics paradigm is that many puzzles and problems in contemporary trade and international economic law can be addressed by reference to "ordinary" domestic law principles, doctrines, and practices. Our third aim, therefore, is to illustrate the promise of taking a more balanced constitutional approach to trade law and policy in a variety of areas. First, we show how fast-track authority amounts to a cession of congressional power, rather than an exercise of itcontrary to the conventional scholarly wisdom. Second, we conclude that the expansion of presidential powers in trade has grown so significant that the President has considerable power to declare trade wars, in spite of Congress's powers under Article I. Congress has simply abdicated the field, without even putting in place the checks and balances afforded to ordinary regulatory policymaking in the administrative state. Third, we explore the specific conditions under which the President has the power to withdraw from trade agreements, such as NAFTA and the WTO. Taking a normalized approach to the role of trade within the separation of powers requires focusing on specific statutory authorizations. This places us at odds with scholars who conclude the President has almost unlimited power in this arena, as well as those who hold the President has virtually no discretion. ${ }^{8}$ Finally, we discuss two developments related to international agreements: the recent trend toward soft law agreements and the impact of international trade agreements on state and local regulations. With respect to what we call "unorthodox international agreements," trade sits uncomfortably. While these agreements have been concluded in a variety of areas, including the Iran Nuclear Deal and the Paris Climate Agreement, Congress's Article I powers suggest greater caution in the use of such

7. See generally Ganesh Sitaraman \& Ingrid Wuerth, The Normalization of Foreign Relations Law, 128 HARV. L. REV. 1897 (2015) (arguing that the "normalization" of foreign affairs law is generally a desirable outcome).

8. See infra Section III.C. 
agreements on commercial matters. Another pressing issue is that international trade agreements increasingly threaten the traditional powers of state and local governments. We call this intersection "trade federalism" and discuss how the imbalance in the constitutional separation of powers on trade issues undermines the commitment to trade federalism embedded in the Constitution.

More broadly, we hope to contribute to debates in both constitutional law and trade law. While constitutional law scholars have occasionally recognized the Janus-faced nature of trade, ${ }^{9}$ they normally focus on the role of treaties in the constitutional system, clumping together trade deals with other kinds of international agreements in spite of trade's explicit and unique connections to Article I powers. ${ }^{10}$ So strong is the foreign affairs paradigm that some have noted that the foreign commerce power can get conflated with the Treaty Power. ${ }^{11}$ International trade scholars, in contrast, pay little attention to the domestic constitutional law framework. To the extent they focus on domestic considerations, they emphasize domestic political constraints rather than the locus of constitutional authority. ${ }^{12}$ Focusing specifically on trade's role within the separation of powers illuminates new issues and contributes to debates in both arenas.

The Article proceeds in three parts. Part I discusses the two paradigms for trade within the separation of powers and argues that the trend towards the foreign affairs paradigm, followed more recently by the movement towards liberalization, has strained trade law and policy. Part II makes the normative

9. See, e.g., Cory Adkins \& David Singh Grewal, Two Views of International Trade in the Constitutional Order, 94 TEX. L. REV. 1495, 1498 (noting two themes in trade policy as American global leadership and American political autonomy and discussing their interplay); Harold Hongju Koh, Congressional Controls on Presidential Trade Policymaking after INS v. Chada, 18 N.Y.U. J. INT'L L. \& POL. 1191, 1192-93 (1986) (noting that trade is divided between Congress and the presidency in the constitutional scheme). For a classic account in this vein, but not one in constitutional law, see Bayless Manning, The Congress, the Executive, and Intermestic Affairs: Three Proposals, 55 FOREIGN AFF. 309-11 (1977) (identifying trade as an intermestic issue, between international and domestic affairs).

10. See, e.g., Curtis A. Bradley, Treaty Termination and Historical Gloss, 92 TEX. L. REV. 773 (2014) (analyzing trade examples as well as general treaty commitments); Curtis A. Bradley \& Jack L. Goldsmith, Presidential Control over International Law, 131 HARV. L. REV. 1201, 1203-04 (2018) (considering a variety of international agreements); see generally Oona A. Hathaway, Treaties' End: The Past, Present, and Future of International Lawmaking in the United States, 117 YALE L.J. 1236 (2008) (examining congressional-executive agreements such as free trade agreements alongside treaties); Oona A. Hathaway, Presidential Power over International Law: Restoring the Balance, 119 YALE L.J. 140 (2009) (considering the range of issues over which Presidents exercise independent authority). For an exception, though one that still focuses on treaties, see John C. Yoo, Laws as Treaties?: The Constitutionality of Congressional-Executive Agreements, 99 MICH. L. REV. 757, 766 (2000).

11. See Scott Sullivan, The Future of the Foreign Commerce Clause, 83 FordHAM L. REV. 1955, 1974 (2015) (describing the conflation of the Commerce Clause and Foreign Commerce Clause and the Treaty Power).

12. See, e.g., Steve Charnovitz, Triangulating the World Trade Organization, 96 AM. J. INT'L L. 28, 43-46 (2002); Frank J. Garcia, NAFTA and the Creation of the FTAA: A Critique of Piecemeal Accession, 35 VA. J. INT'L L. 539, 578 (1995) (discussing the interplay of bloc accession to NAFTA with domestic politics). 
argument against overly emphasizing trade's relationship to foreign affairs. Part III discusses implications for a variety of debates in constitutional and statutory law. A brief conclusion follows.

I.

\section{TRADE AND THE SEPARATION OF POWERS: TwO PARADIGMS}

Trade has been a central object of public policy since the founding of the country. The Constitution speaks directly on questions of trade, rooting considerable powers in Congress while reserving other powers to the President. The result is that trade exists in a precarious position in our constitutional system. From the founding through the early twentieth century, trade was largely seen as a domestic economic issue, with its constitutional home in Congress. In the midtwentieth century, trade became a foreign affairs issue, and a new paradigm emerged, with authority shifting to the President. Today both paradigms have broken down, and trade policy has become increasingly unmoored from either traditional domestic economic or foreign policy objectives. The result has been conflict and controversy.

\section{A. Trade as Domestic Economics: The Founding Through the Long Nineteenth Century}

While scholars have recognized that trade law operates at the nexus of both domestic and foreign affairs, these two approaches to trade within the constitutional system have been surprisingly underdeveloped. We define the domestic economics paradigm to include three different components: (1) the goals of trade policy are focused on domestic economic issues, (2) the constitutional home for trade policy is within Article I, and (3) the functionally desirable locus of trade policy is in Congress.

Textually, Article I empowers Congress with a variety of tools to govern trade policy. The most obvious sources of congressional power are the ability to "regulate [c]ommerce with foreign [n]ations," to "lay and collect [t]axes, [d]uties, [i]mposts, and [e]xcises," and to make any laws "necessary and proper" to executing its Article I powers or any other grant of power elsewhere in the Constitution. ${ }^{13}$ In addition, the Origination Clause mandates that "[a]11 [b]ills for raising [r]evenue shall originate in the House of Representatives." 14 Scholars have argued that if generating revenue is the main purpose of a statute governing international trade, then the Constitution requires both houses of Congress to be involved (and, by implication, bars the use of the Treaty Power to accomplish the same goals). ${ }^{15}$

13. U.S. CONST. art. I, § 8 .

14. Id. art. I, § 7 .

15. See Rebecca M. Kysar, On the Constitutionality of Tax Treaties, 38 YALE J. INT'L L. 1, 56 (2013) (arguing that the Origination Clause requires House consideration for tax treaties); Yoo, supra note 10, at $811 \mathrm{n} .218$ (describing congressional treatment). 
Functionally, bargaining over economic policy has been understood as appropriately within the domain of Congress. Even at the Founding, the United States was a country of diverse economic interests, from bankers in New York to small farmers in New England to plantation owners in South Carolina. Today, of course, the geographic growth of the United States and the staggering complexity of the world's largest economy has amplified that diversity. Congress reflects this diversity of economic interests in a way that the President, elected both indirectly and nationally, cannot. Members of Congress have smaller constituencies, are elected directly by the people, and (in the case of the House of Representatives) face election at greater frequency. As a result, the legislature is well-suited to capture the diversity of preferences and interests in a large and extended republic.

When the legislature directly makes trade policy, this diversity of interests has often led Congress to protect American markets. In part, this protectionist bent reflects the deliberately local way that members of Congress interact with their constituents. Businesses of modest size that suffer from foreign competition can effectively influence their congressional representatives' views on trade policy, even if they cannot reach the more remote executive branch. ${ }^{16}$ But Congress's protectionist tendencies also reflect Congress's tendency to use trade policy to achieve domestic economic goals, such as redistribution. ${ }^{17}$ Of course, it is not necessarily true that protectionism and the use of trade policy to pursue domestic economic policy-making goals need be married to congressional power. We could easily imagine a protectionist President and a laissez-faire Congress. Indeed, President Trump and the Republican-controlled Congress of his first two years in office arguably fit this rare configuration. But over two centuries of American history, congressional power and the domestic goals of trade policy have largely been in alignment. ${ }^{18}$

The origins of Congress's power to collect tariffs and the parallel provision barring the states from establishing tariffs demonstrates this alignment. Under the Articles of Confederation, the United States government suffered from a severe lack of revenue. ${ }^{19}$ The government needed funds to repay foreign nations that had supported the insurgent country during the Revolutionary War, to cover the costs of running the government, to pay veterans, and to fund the army's battles against Indians on the western frontier. ${ }^{20}$ The Confederation Congress,

16. See Charan DeVEREAUX, Robert LaWrence \& Michael Watkins, CASE StUdies IN U.S. TRADE NegOtiation, Vol. I: MAKING THE RULES 188-191 (2006).

17. Cf. Robert D. Putnam, Diplomacy and Domestic Politics: The Logic of Two-Level Games, 42 INT'L ORG. 427, 433 (1988) (analyzing "the impact of the international economy on domestic politics and domestic economic policy"); see also PAUL KRUGMAN \& MAURICE OBSTFELD, INT'L ECONOMICS: THEORY \& POLICY 214-17 (7th ed. 2005) (analyzing the argument against free trade that "imperfections in the internal functioning of an economy may justify interfering in its external economic relations").

18. See, e.g., Koh, Congressional Controls, supra note 9, at 1194 (describing the Smoot-Hawley tariff regime and associating the institutional choice of Congress with protectionist policies).

19. ROGER H. BROWN, REDEEMING THE REPUBLIC 12 (1993).

20. Id. at $12,26$. 
however, could not establish a nationwide tariff (or "impost") without the unanimous consent of the States. Rhode Island (and later New York) balked because it had its own tariff and feared the loss of state revenue. ${ }^{21}$ As a result, the Confederation Congress was left to issue "requisitions," or requests to the States to fund the confederation government. The States responded with taxes, many of which were regressive, on their citizens. ${ }^{22}$ Coming in the midst of a severe postwar economic depression, state-imposed taxes led to widespread revolts across the country. The most famous one was Shays' Rebellion, but protests, conflict, and even armed insurrection were common from Massachusetts to Pennsylvania to Virginia and North Carolina. ${ }^{23}$ So important were these economic sources of domestic discontent that Alexander Hamilton captured the origins of the Philadelphia Convention in three words: "Impost begat Convention." 24

The tariff clauses of the Constitution were a response to these domestic challenges. The goal of the tariff clauses was twofold: revenue and redistribution. On the revenue side, a nationwide tariff would provide a source of revenue to fund the new government. On the redistribution side, advocates argued that a tariff would have two effects. First, it would allow the States to reduce or eliminate their regressive taxes. ${ }^{25}$ Second, it would redistribute the burdens of government (and therefore help farmers, artisans, and other lower-class people) because the tariff would largely fall on luxury and manufactured goods that wealthier people consumed. ${ }^{26}$ When the first Congress passed a tariff in 1789 (the tariff was the second act of Congress after a bill establishing the oath of office), states slashed their tax rates considerably, in some cases by more than 90 percent. ${ }^{27}$ The tariff's origins were thus tied to domestic economic questions of revenue and redistribution, as well as to federalism concerns about whether to tax at the state or national level. ${ }^{28}$

Over the course of the nineteenth century, trade law and policy were virtually coextensive with the tariff. ${ }^{29}$ The justification for tariffs shifted over

21. Id. at 22-24; see also WOODY HOLTON, UNRULY AMERICANS AND THE ORIGINS OF THE CONSTITUTION 136 (2007); E. JAMES FERGUSON, THE POWER OF THE PURSE 152-53, 239-40 (1961).

22. See Holton, supra note 21, at 65-66 (describing the methods states used to comply with requisition); BROWN, supra note 19, at 36-37 (noting "[d]irect taxes levied by the states during the 1780 s consisted of a mixture of progressive and regressive taxes").

23. See Holton, supra note 21, at 145-46 (finding widespread rebellion to debt collection). On Shays' Rebellion, see generally DAVID P. SATZMARY, SHAYS' REBELLION (1980).

24. Alexander Hamilton, New York Ratifying Convention Notes for a Second Speech of July 17, in 5 THE PAPERS OF ALEXANDER HAMILTON 173 (Harold Syrett ed., 1962).

25. See Ganesh Sitaraman, The Crisis of the Middle-Class Constitution 82-87 (2017) (identifying excessive taxation as one of the problems the Constitution solved).

26. Id.

27. See Max M. Edling, A Revolution in FAVOr OF Government 211-12 (2003).

28. For a discussion of the broader federalism implications of trade policy, see infra Part IV.

29. Of course, there were treaties that also implicated other trade issues, such as the Jay Treaty of 1795, which, as part of a larger settlement of issues between the United States and Britain, established that Britain and the United States would trade on a most-favored-nation basis (while at the same time 
time, but the central purposes of tariffs were all tied to domestic economics: revenue, internal improvements, protection of industry, encouragement of infant industry, and safeguarding labor. In the early republic, Henry Clay sought to link the revenue generated by tariffs to funding internal improvements, such as canals and roads, which would connect the remote western parts of the United States to the East Coast. ${ }^{30}$ At the same time, tariffs would benefit the Northeast by protecting infant manufacturing operations from foreign competition. ${ }^{31}$ Clay's "American System" thus redistributed wealth from the East toward the lessdeveloped West, while still providing a benefit to northeasterners. ${ }^{32}$ Southerners opposed Clay's American System. They sought to decouple internal improvements from the tariff and advocated for a "tariff for revenue only" instead of a tariff for the protection of domestic industry. ${ }^{33}$ On their analysis, the tariff was largely a tax-and-transfer regime designed to redistribute wealth from the South to the North and West. ${ }^{34}$

By the second half of the nineteenth century, the justifications for the tariff shifted towards industrial and labor protection. ${ }^{35}$ Industrialization had caused significant domestic economic disruption, as artisanal labor shifted to factories and agriculture composed an increasingly smaller share of the economy. To mitigate the "social dislocations generated by the industrial revolution," the Republican Party advocated for tariffs as a way to keep wages high for American workers. ${ }^{36}$ In the absence of the tariff, they argued, the American market would be flooded by cheap goods made by low-wage workers in foreign countries. ${ }^{37}$ So

restricting American access to markets in Britain's Caribbean colonies). More generally, treaties of "friendship, commerce, and navigation" often contained provisions requiring nondiscriminatory treatment of foreign-merchant vessels and their cargo; however, such treaties did not regularly contain the more general nondiscrimination rules found in modern trade agreements until the middle of the twentieth century. See John F. Coyle, The Treaty of Friendship, Commerce and Navigation in the Modern Era, 51 COLUM. J. TRANS. L. 302,312 (2013) ("The treaty generally ensures that, upon a treaty vessel's arrival at these ports, it shall receive preferential treatment with respect to the payment of tonnage duties and harbor fees. Many of these treaties also exempt cargo carried on foreign vessels from discriminatory customs duties levied on such cargo.").

30. See Douglas Irwin, Clashing Over COMMERCE: A History OF US TRADE POlicy 157 (2017) (explaining how the Senate used internal improvements to incentivize tariff votes).

31. See Frank William Taussig, The TarifF History of the United States $1,23\left(6^{\text {th }}\right.$ ed. 1913) (describing "protection to young industries"). Earlier, during President Jefferson's administration, the Embargo and Non-Intercourse acts had a similar effect, spurring domestic manufacturing. Id. at 1617. The War of 1812 made clear the military necessity of domestic manufacturing and the role that a tariff might play in supporting homegrown industry. Indeed, during this period, even famous skeptics of the tariff, like John C. Calhoun, supported high tariffs because they were "connected with the security of the country." IRWIN, supra note 30, at 130.

32. For an overview, see MaUrice G. BAXTER, Henry Clay AND the AMERICAN SySTEM (1995).

33. IRWIN, supra note 30, at 154-55.

34. Id. at 159-60.

35. See James L. Huston, A Political Response to Industrialism: The Republican Embrace of Protectionist Labor Doctrines, 70 J. AM. HIST. 35, 36 (1983).

36. Id. at 35 .

37. Id. at 45 ; TAUSSIG, supra note 31 , at $65-66$. 
strong was the protectionist justification for tariffs that by the 1870s advocates pushing to reduce tariffs did not argue that Congress should abolish protectionist tariffs. ${ }^{38}$ Instead, they pushed to restrict tariffs to only items with protectionist benefits. ${ }^{39}$ They succeeded in eliminating a variety of non-protective duties (that is, revenue-raising duties, such as the tariffs of coffee and tea). ${ }^{40}$

Throughout this period, often referred to as the long nineteenth century, Congress exercised direct control over tariff policy, passing laws enumerating in great detail every item to which a duty applied. The McKinley Tariff of 1890, for example, had a schedule on "Chemicals, Oils, and Paints," which included acetic or pyroligneous acid, boracic acid, chromic acid, citric acid, sulphuric acid, tannic acid, alcoholic perfumery, alumina, ammonia, blacking of all kinds, blue vitriol, bone-char, borax, camphor, chalk, and chloroform, among many other items. ${ }^{41}$ Interest groups vigorously advocated around tariff determinations, and members of Congress were deeply involved in the details of tariff rates that supported constituent industries.

More than just being involved in setting tariffs, Congress also attempted to assert its constitutional authority over trade-related issues, in particular by checking the use of the Treaty Power as a way to avoid engaging the House of Representatives. The worry was that under the Treaty Power, the Senate and the President could come to an agreement with the force of law (under the Supremacy Clause) while excluding the House of Representatives from the process of policy-making. Members of the House asserted their prerogative under Article I with respect to the domestic effect of such treaties. During an 1815 debate in Congress on crafting a commercial treaty with Great Britain, for example, Representative Cyrus King of Massachusetts argued that any treaty that covered a topic related to one of Congress's Article I powers had to go through the House of Representatives to take effect. ${ }^{42}$

The House was particularly protective of its central constitutional role in taxation. It passed a resolution in 1880 stating that the use of the Treaty Power to set tariff rates would "be an infraction of the Constitution and an invasion of one of the highest prerogatives of the House of Representatives." 43 An 1885 House Report resolved that "the President by advice and consent of the Senate,

38. See TAUSSIG, supra note 31 , at $188-89$.

39. Id.

40. Id.

41. McKinley Tariff of 1890, Act of Oct. 1, 1890, 26 Stat. 567 [hereinafter McKinley Tariff].

42. See Quincy Wright, Treaties and the Constitutional Separation of Powers, 12 AM. J. INT'L L. 64, 68 (1912); 29 ANNALS OF CONG. 538 (1816) (“[W] henever a treaty or convention does, by any of its provisions, encroach upon any of the enumerated powers vested by the constitution in the Congress of the United States, or any of the laws enacted by them in execution of those powers, such treaty or convention, after being ratified, must be laid before Congress, and such provisions cannot be carried into effect without an act of Congress."). Of course, views were not uniform on this point. See, e.g., 2 ASHER C. Hinds, Hinds' PreCEDENTS OF THE House OF REPRESENTATIVES OF THE UNited STATES 979-80 (1907) (discussing an 1820 debate in the House of Representatives).

43. Wright, supra note 42 , at 68. 
cannot negotiate treaties with foreign Governments by which the duties levied by Congress can be changed or abrogated, and such treaties to be operative as law must have the sanction of an act of Congress." ${ }^{44}$ Indeed, one classic study of treaties concluded that in every treaty affecting revenue between 1796 and 1913, the House of Representatives "uniformly insisted upon, [and] the Senate has acquiesced in, legislation by Congress." 45

Congress also asserted itself with respect to the termination of commercial treaties. Congressional legislation terminated treaties of amity and commerce with France in 1798. Years later, Thomas Jefferson wrote that " $[t]$ reaties being declared, equally with the laws of the U[nited] States, to be the supreme law of the land... an act of the legislature alone can declare them infringed and rescinded. This was accordingly the process adopted in the case of France in 1798." ${ }^{\prime 4}$ More than a century later, in 1911, President William Howard Taft sought to terminate a commercial treaty with Russia. The question was whether President Taft needed to gain consent from the Senate alone or from both houses of Congress. At the time, a variety of commentators, Senators, and Representatives argued that the House of Representatives needed to have a say in the process. ${ }^{47}$

This is not to say that all three components of the domestic economics paradigm - domestic economic goals, a focus on Article I, and a preeminent role for Congress-were always satisfied in the nineteenth century. Some statutes during this period did delegate powers to the President to execute laws related to foreign trade. A 1794 statute, for example, authorized the President "whenever, in his opinion the public safety shall so require ... to lay an embargo on all ships and vessels ... under such regulations as the circumstances of the case may require, and to continue to revoke the same, whenever he shall think proper." 48 Passed a year after President George Washington's Neutrality Proclamation, which aimed to keep the United States out of the war between France and Britain, this statute gave the President the power-only when Congress was not in session - to enforce US neutrality at US ports. ${ }^{49}$ Similar delegations of power

44. Kysar, supra note 15 , at 45 \& n. 275 .

45. SAMUEL B. CRANDALl, TREATIES: THEIR MAKING AND ENFORCEMENT 195 (2d ed. 1916); Kysar, supra note 15 , at 43.

46. Bradley, supra note 10 , at 789 .

47. Louis Marshall testified "that the power [to terminate] rests in Congress." Senator Isidor Rayner argued that "[a] treaty is the supreme law of the land under the language of the Constitution, and the supreme law of the land ought not to be set aside except by legislative action of both Houses." Representatives Legare and Peters agreed. See Bradley, Treaty Termination, supra note 10, at 795 \& nn. $113 \& 118$.

48. Francis B. Sayre, The Constitutionality of the Trade Agreements Act, 39 COLUM. L. REV. 751, 759-60 (1939) (citing Act of June 4, 1794, 1 Stat. 372 and listing other early nineteenth century statutes on point).

49. See Myres McDougal \& Asher Lans, Treaties and Congressional-Executive or Presidential Agreements: Interchangeable Instruments of National Policy: I, 54 YALE L.J. 181, 248, 252 \& n.178 (1945). 
continued through the Quasi-War with France and throughout the Jefferson and Madison administrations, as part of the policies that ultimately led to the War of $1812 .{ }^{50}$ But by and large, trade policy was defined by considerations of domestic economic policy and by congressional exercise of its Article I authorities.

Shifting domestic economic policies and politics in the late nineteenth and early twentieth centuries weakened both the protectionist and revenue justifications for the tariff. Critics of the tariff increasingly argued that protectionist tariffs were no longer encouraging infant industry but instead protecting established monopolies. ${ }^{51}$ After the Great Merger Movement of 18951904, which led to massive consolidation across sectors of the American economy, domestic policy and politics became increasingly focused on the power of trusts and monopolies. ${ }^{52}$ This shift had important implications for tariff policy. Critics argued that tariffs were harming competition by effectively protecting domestic monopolies from foreign competitors. The tariff, in the words of some commentators, was "the mother of all trusts. ${ }^{" 53}$ Efforts to regulate monopolies, they argued, required reducing tariffs.

The revenue justification also became weaker. During the Civil War, Congress established an income tax to raise revenue in addition to the tariff to cover the costs of warfighting. ${ }^{54}$ Two generations later, in 1913, Congress passed and the States ratified the Sixteenth Amendment to the Constitution, authorizing Congress to create an income tax. Over time, taxation supplanted the tariff as the primary source of revenue for the nation. While customs and excise taxes constituted 90 percent of federal revenues in 1880, that number had dropped to 25 percent by $1930 .{ }^{55}$ The income tax contributed nothing to the federal fisc in 1880 but made up 59 percent of revenues by $1930 .{ }^{56}$ This interchangeability of income taxes and tariffs confirms the role that the tariff played with respect to revenue and the distribution of economic burdens. ${ }^{57}$ As the revenue justification grew weaker, the tariff became less necessary to the exercise of Congress's other Article I powers.

Some commentators have argued that the core breaks in American trade policy were the Civil War (after which protectionism became the dominant

50. See Sayre, supra note 48, at 759-60 (noting the pattern of delegation through the beginning of the nineteenth century).

51. See TAUSSIG, supra note 31, at 362-63 (describing the hostility to trusts and tariffs); IRWIN, supra note 30 , at 313 .

52. NaOmi LamoreauX, The Great Merger Movement in AMERICAN Business, 1895 1904 (1985).

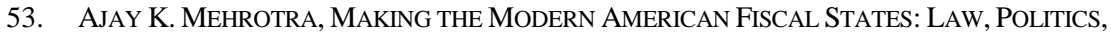
AND THE RISE OF PROGRESSIVE TAXATION, 1877-1929, at 50 (2013) (quoting a contemporary sugar magnate's confession).

54. Id. at 7.

55. Id.

56. Id.

57. Indeed, the Revenue Act of 1916 included both tax and tariff provisions. IRWIN, supra note 30 , at 340 . 
rationale for American trade policy) and the New Deal (the end of protectionism and the shift to presidential power).$^{58}$ There is some truth in these characterizations, especially when viewed in terms of the constitutional and functional home for trade policy. But the shift from the domestic economics paradigm to the foreign affairs paradigm took place over a longer time frame. The transition from the tariff to domestic taxes as a source of revenue, for example, began during the Civil War and leaped forward during the Progressive Era with the Sixteenth Amendment. And while the central shift from congressional power to presidential authority was during the presidency of Franklin Roosevelt, the origins of congressional efforts to delegate power to the President began prior to the New Deal. ${ }^{59}$

More importantly, these inflection points tend to focus on the outputs of trade policy: high versus low trade barriers or protectionism versus liberalization. They are divorced from the underlying goals of trade policy: domestic economic objectives or foreign policy objectives. Protectionism is not, however, synonymous with a trade policy driven by domestic economic policy. Trade liberalization, too, can be enacted in pursuit of domestic economic objectives, as in the case of using foreign competition to regulate domestic monopolies. And protectionism can be a tool of foreign policy. It is the goals of trade policy that more accurately characterize these eras, and confusion about goals that characterizes our current trade policy.

\section{B. Trade as Foreign Affairs: The Rise and Rise of Presidential Trade Powers}

As with the domestic economics paradigm, the foreign affairs paradigm includes three components: (1) the goals of trade policy are focused on the behavior of or relationships with foreign countries, (2) the constitutional home for trade policy is within Article II, and (3) the functionally desirable locus of trade policy is the executive branch.

The foreign affairs aspects of trade law are well understood. A central task of trade policy is making agreements with foreign countries so that the foreign country will lower its tariff rates, thereby opening its markets to US exports. But foreign affairs aims go beyond setting tariff rates. Trade is also a tool for advancing geopolitical goals; trade agreements can be used to benefit allies, reward countries who follow American leadership, or sanction those who pursue actions opposed to US foreign policy objectives. ${ }^{60}$ Finally, trade agreements are

58. Irwin divides the history this way. See IRWIN, supra note 30. Ackerman \& Golove focus on the New Deal and the end of World War II as constitutional moments. Bruce Ackerman \& David Golove, Is NAFTA Constitutional?, 108 HARV. L. REV. 799 (1995).

59. See, e.g., McKinley Tariff, supra note 41; Ackerman \& Golove, supra note 58, at 821-25 (marking the change in the delegation to the executive for this tariff).

60. On trade as geopolitics, see generally JENNIFER M. HARRIS \& ROBERT D. BLACKWILL, WAR BY OTHER MEANS: GEOECONOMICS AND STATECRAFT (2016). On sanctions and international 
a way for the United States to exercise international leadership; agreements can set the "rules of the road" for countries around the globe to follow. ${ }^{61}$

The executive branch is traditionally considered functionally superior at making policy judgments on such issues. Unlike a multibranch and multimember legislature, the executive branch consists of a singular president. ${ }^{62}$ A single president at the head of a relatively unitary executive branch is better able to negotiate with foreign nations without confusion or cacophony, to access secret intelligence that might be valuable in making geopolitical assessments, and to move with alacrity when necessary. As a result, it is preferable for the executive branch, not the legislature, to exercise foreign affairs powers. Indeed, Article II gives the President a variety of tools to conduct American foreign affairs. The President is the Commander in Chief of the military, has the power to appoint and receive ambassadors, and can recognize foreign governments. ${ }^{63}$ Congress has a variety of foreign affairs powers as well, ${ }^{64}$ but given the strengths of the President in the realm of foreign policy, Congress has largely acquiesced to the President's preeminent role in the field.

Over the course of the twentieth century, the foreign affairs paradigm became the dominant approach to trade policy. This transformation in trade law was a function of four different factors. First, Congress believed there were policy benefits in delegating trade authority and insulating tariff rate-setting from congressional logrolling. ${ }^{65}$ Second, the Supreme Court in the mid-twentieth century transformed the constitutional law of foreign relations, granting increasingly expansive power to the President. Third, in the post-World War II

economics as a weapon against those opposed to US interests, see, for example, JUAN ZARATE, TREASURY'S WAR: THE UNLEASHING OF A NEW ERA OF FINANCIAL WARFARE (2013).

61. See, e.g., Barack Obama, The TPP would let America, not China, Lead the Way on Global Trade, WASH. POST (May 2, 2016), https://www.washingtonpost.com/opinions/president-obama-thetpp-would-let-america-not-china-lead-the-way-on-global-trade/2016/05/02/680540e4-0fd0-11e6-93ae50921721165d_story.html?noredirect=on\&utm_term=.4340d1028fa7 [https://perma.cc/DN49-4LDE] ("As a Pacific power, the United States has pushed to develop a high-standard Trans-Pacific Partnership, a trade deal that puts American workers first and makes sure we write the rules of the road for trade in the 21st century.").

62. We say "relatively" because the President sits atop a complex bureaucracy, whose members have considerable power to shape and constrain presidential actions. Commentators have noted that the presidency is a "they," not an "it." See Cass R. Sunstein, The Office of Information and Regulatory Affairs: Myths and Realities, 126 HARV. L. REV. 1838, 1840 (2013).

63. See, e.g., Zivotofsky v. Kerry, 135 S. Ct. 2076, 2084-85 (2015) (holding that the President has the exclusive right to recognize foreign sovereigns based on the Reception Clause).

64. U.S. CONST. art. I, § 8 (including, among other things, the power to "declare [w]ar").

65. While trade liberalization might have become more popular among elected officials over the course of the twentieth century, this alone does not explain the shift in US trade policy over the same time frame. Rather, the foreign affairs paradigm played a critical role in justifying the delegation of power to the executive branch and in how the President subsequently exercised those delegated powers. Indeed, it is not even clear that policy-makers did in fact converge on a pro-trade-liberalization ideology. See generally Jide O. Nzelibe, The Illusion of the Free-Trade Constitution, 19 LEG. \& PUB. POL'Y 1 (2016) (arguing that the decision to delegate power was not a way for Congress to overcome interest group pressure against trade liberalization, as conventionally understood, but itself a function of interest group pressure). 
era, the country entered an exceptional period of economic growth, in which domestic economic issues were less salient and Cold War foreign policy objectives became more important. Finally, Congress failed to reassert itself as the President negotiated increasingly broad trade agreements.

Starting in the late nineteenth century, members of Congress grew concerned that the legislative process was reaching undesirable tariff rates because of legislative horse-trading and interest group influence. Thus, at first, delegations to the executive were seen as a way to get better information about the effects of tariff rates. In 1866, Congress appointed David Wells as Special Commissioner of the Revenue, charging him with issuing reports to Congress on tariff and revenue rates. ${ }^{66}$ In 1882, in response to advocacy from President Chester A. Arthur, Congress created a Tariff Commission (since renamed the International Trade Commission, or ITC) to hold hearings and collect testimony on tariff issues. ${ }^{67}$

The first delegations of authority to set tariff rates took place in 1890 with the McKinley Tariff. ${ }^{68}$ Congress exempted some goods from a tariff, unless the President determined that the foreign country had imposed unfair tariff rates on American products. When the tariff was challenged as an unconstitutional delegation, the Supreme Court sustained the delegation, holding that the President was simply executing a law passed by Congress. ${ }^{69}$ Field v. Clark opened the door to more expansive delegations of tariff-setting authority. The Fordney-McCumber Tariff of 1922 included a "flexible tariff" provision, which allowed the President to change tariff rates by as much as 50 percent to account for differentials in foreign and domestic production costs. ${ }^{70}$ The idea behind the flexible tariff provision was that production cost differentials could be scientifically calculated, thereby insulating tariff rates from the realm of politics. Economists tasked with calculating those rates thought the enterprise was futile because of technical difficulties related to estimating foreign and domestic production costs and because of inevitable judgment calls in analyzing markets. ${ }^{71}$

66. See IRWIN, supra note 30, at 223-24.

67. Id. at 233-34.

68. See Sayre, supra note 48, at 761 (identifying the sections of the tariff that give the executive unprecedented power). See generally McKinley Tariff, supra note 41.

69. Field v. Clark, 143 U.S. 649, 672 (1892) (upholding the tariff as law); see also Hathaway, supra note 10, at 1294 (noting the lack of a further congressional-approval requirement).

70. For a discussion, see IRWIN, supra note 30, at 356; see also Daniel K. Tarullo, Law and Politics in Twentieth Century Tariff History, 34 UCLA L. REV. 285, 298 (1986) (describing tariff reform in the early 1900s); George Bronz, The Tariff Commission as a Regulatory Agency, 61 COLUM. L. REV. 463, 465 (1961) (identifying the limits of presidential tariff power in the Fordney-McCumber Act). In between, the Payne-Aldrich Act of 1909 created a tariff board to investigate production cost differentials, but this system ended in 1912. IRWIN, supra note 30, at 326. The 1916 Tariff Act re-created the Tariff Commission with an advisory power. Tarullo, supra, at 302.

71. See John Day Larkin, THE PReSident's Control of THE TARIFF 115-31(1936) (describing issues with defining the principal market in the United States, the principal competing country, and production areas, and addressing marginal producers, weighted averages, joint costs, 
Yet despite experts' beliefs that the executive could not reach a technocratic answer, the Supreme Court upheld the flexible tariff delegation. ${ }^{72}$

Congress's last experiment with directly setting tariff rates on a major scale came in 1930, with the infamous Smoot-Hawley Tariff (Smoot-Hawley). There, Congress raised the average tariff by approximately 20 percent. ${ }^{73}$ Politicians and commentators widely associated Smoot-Hawley with a string of economic calamities that followed. Over the next two years, the volume of US imports and exports fell by approximately 40 percent each. ${ }^{74}$ Blaming Smoot-Hawley, a number of foreign countries enacted retaliatory tariffs that further dampened international trade. ${ }^{75}$

With two blockbuster Supreme Court precedents and the Smoot-Hawley experience, Congress decided to abandon tariff-making. In 1934, Congress passed the Reciprocal Trade Agreements Act (RTAA). In contrast to congressionally enacted tariff schedules that ran on for pages, the entirety of the RTAA was only three pages long. It gave the President the power to enter into trade agreements with other nations that reduced tariff rates by up to 50 percent. The President implemented the changes through Executive Order, and neither the international agreement nor the resulting tariff modifications required any additional input from Congress. ${ }^{76}$ In addition, the President's modified rates

similar goods, loss and appreciation, labor expenses, and distribution costs); IRWIN, supra note 30, at 356 (detailing the memorandum proposing the provision).

72. See J.W. Hampton, Jr., \& Co. v. United States, 276 U.S. 394, 409 (1928) (finding the delegation constitutional).

73. Douglas A. Irwin, The Smoot-Hawley Tariff: A Quantitative Assessment, 80 REV. ECON. \& STAT. 326, 327 (1998) (noting that, while it is difficult to come up with an average figure across all tariff lines, one popular estimate of the increase from Smoot-Hawley yields a figure of 17.4 percent).

74. Id. at 326 .

75. See League of NATIONS, WorLd ECON. SuRVEy, 1932-33, at 193 (1933) (“[T]he HawleySmoot tariff in the United States was the signal for an outburst of tariff-making activity in other countries, partly at least by way of reprisals.”). Eichengreen and Irwin argue that the conventional wisdom that countries universally enacted protectionist measures during the Great Depression is mistaken. Rather, they find significant variation in the extent to which countries enacted protectionist measures. Countries that remained on the gold standard could not use monetary policy to respond to the economic crisis, so they enacted trade restrictions; countries that abandoned the gold standard could devalue their currency, so they did not enact protectionist policies. See generally Barry Eichengreen \& Douglas A. Irwin, The Slide to Protectionism in the Great Depression: Who Succumbed and Why?, 70 J. ECON. HISTORY 871 (2010). Likewise, scholars have hotly contested the extent to which SmootHawley contributed to the Great Depression. Empirical studies have found a relatively small effect, with at least one study suggesting that Smoot-Hawley may have acted as a modest stimulus in the face of a larger economic contraction that was already underway before Smoot-Hawley was passed. See Barry Eichengreen, The Political Economy of the Smoot-Hawley Tariff, in RESEARCH IN ECONOMIC HISTORY 1, 29 (Roger L. Ransom \& Peter H. Lindert eds., 1989). Other studies have suggested that SmootHawley's impact may have had a larger indirect impact. See, e.g., Allan Meltzer, Monetary and Other Explanations for the Start of the Great Depression, 2 J. MONETARY ECON. 455 (1976) (arguing that Smoot-Hawley's effects worked through its monetary effects); see also Irwin, supra note 73, at 326 (reviewing the literature on Smoot-Hawley's relationship to the Great Depression).

76. See IRWIN, supra note 30, at 425 (detailing the "sweeping" authority Congress granted President Roosevelt). 
would remain in place for "three years even if Congress changed the underlying statute." 77

This delegation of power was remarkably unconstrained. Unlike equivalent executive agencies, the Tariff Commission was not authorized to make rules to guide executive discretion, nor did courts take it upon themselves to do so. ${ }^{78}$ Instead, power was concentrated in the presidency, without procedural or other mechanisms for participation, transparency, or principles for rate-setting. ${ }^{79}$ The only significant constraint was a sunset provision. Some protectionist Republicans at the time said the bill created a "fascist dictatorship in respect to tariffs" that gave Roosevelt "extraordinary, tyrannical, dictatorial power over the life and death of the American economy." 80

The expansive delegation of authority over trade law to the President - and the Supreme Court's decisions sustaining such delegations - coincided with a great transformation in the constitutional law of foreign affairs, in which "foreign affairs exceptionalism" took hold. Under this approach, foreign affairs issues are interpreted as categorically different from domestic affairs as a constitutional matter. In particular, foreign affairs issues are seen as the province of the federal government, rather than the States; are considered ill-suited to adjudication in federal court and therefore subject either to the political question doctrine or expansive deference; and, within the political branches, are the predominant-if not exclusive - domain of the President. ${ }^{81}$ The Supreme Court set out some of these doctrines in a series of important cases during the 1930s and 1940s, in which it ratified expansive exercises of executive power even absent Article II textual commitments. In United States v. Belmont and United States v. Pink, the Court gave preemptive weight to Franklin Roosevelt's agreement recognizing the Soviet Union and negotiating claims with the communist country. ${ }^{82}$ In United States v. Curtiss-Wright, the Court upheld a delegation to the President in the foreign affairs context, while announcing "the very delicate, plenary and exclusive power of the President as the sole organ of the federal government in the field of international relations - a power which does not require as a basis for its exercise an act of Congress ...." 83

If congressional delegations and the Supreme Court's tolerance of them established the legal framework for the foreign affairs paradigm in trade, American prosperity in the post-World War II era provided the economic foundation. During that period, trade became increasingly seen as a geopolitical

77. Ackerman \& Golove, supra note 58, at 848-49.

78. Tarullo, supra note 70, at 326-27.

79. On the constitutionality of the RTAA, see Sayre, supra note 48.

80. IRWIN, supra note 30, at 428.

81. For a discussion of foreign affairs exceptionalism, see Sitaraman \& Wuerth, supra note 7.

82. United States v. Belmont, 301 U.S. 324 (1937); United States v. Pink, 315 U.S. 203 (1942).

83. United States v. Curtiss-Wright Export Corp., 299 U.S. 304, 320 (1936). 
tool to assert American leadership around the world - and in particular to shore up support for the West during the Cold War. ${ }^{84}$

Economically, the post-World War II era was exceptional in American history. It was a period of relative economic equality; a growing economy meant rising middle class wages for families of all races (despite significant disparities between races) ${ }^{85}$ With Western Europe and Japan in ruins from the war, the United States was the "only major industrial nation with its production capacity not only intact but enlarged as a result of the conflict." 86 In 1937, the United States captured 17 percent of global trade in manufactured goods; by 1954, it captured 26 percent. ${ }^{87}$ Massive export capacity meant jobs for workers and higher wages. As a result, even unions supported trade liberalization in the postwar years ${ }^{88}$ Skeptics recognized the unique economic circumstances at the time. As Senate Finance Committee Chairman Eugene Millikin observed, "In anything resembling normal times, some of the cuts [to tariffs] would be catastrophic ... . Copper, livestock, livestock products such as hides and wool, numerous metals, agricultural products - all of these things can be produced cheaper abroad than here." 89

With a strong economy at home, concern shifted to foreign affairs, particularly with the rise of communism. In 1947, President Harry Truman joined the General Agreement on Tariffs and Trade (GATT), relying on the RTAA's ex ante grant of authority to enter into tariff-reducing trade agreements. ${ }^{90}$ Indeed, in running for reelection in 1948, President Truman defended the RTAA as one of the "best assets we can have for peace." "91 In 1949, Secretary of Defense James Forrestal told Congress that the Pentagon viewed renewing the RTAA as "a step in the interest of national security." 92 In the same debate, Senator A. Willis Robertson asked rhetorically, "What is the cold war about? It is over trade."93 Presidents Dwight E. Eisenhower and John F. Kennedy also argued for trade agreements on the ground that they would help expand freedom against the ongoing threat from communism. ${ }^{94}$

84. IRWIN, supra note 30, at 495.

85. See, e.g., THOMAS PIKETTY, CAPITAL IN THE TWENTY-FIRST CENTURY (2013); SITARAMAN, supra note 25, at 201-02, 206.

86. IRWIN, supra note 30, at 492 .

87. Id.

88. Id. at 493 .

89. Id. at 483 .

90. Koh, supra note 9, at 1195; IRWIN, supra note 30, at 486.

91. Thomas W. Zeiler, Managing Protectionism: American Trade Policy in the Early Cold War, 22 DiPLOMATIC HIST. 337, 354 (1998) (quoting President Truman).

92. Id. at 356 .

93. Id.

94. Eisenhower, for example, called on Congress to support creation of an Organization for Trade Cooperation (OTC) to administer the GATT in 1955, saying that the failure to do so would "play directly into the hands of the Communists." His 1955 State of the Union address declared that "[w]e must expand international trade and investment and assist friendly nations whose own best efforts are still insufficient to provide the strength essential to the security of the free world." Kennedy called trade 
The GATT's odd origins in the postwar settlement marked a turning point with respect to the foreign policy objectives inherent in, as well as presidential control of, US trade policy. At the Bretton Woods conference in 1944, the United States and its allies conceived of three organizations that would regulate international economic affairs: the World Bank, the International Monetary Fund, and the International Trade Organization (ITO). ${ }^{95}$ Leaders intended these institutions to preserve peace and security by "putting a break on beggar-thyneighbor protectionist policies" believed to have contributed to World War II. ${ }^{96}$ While nations negotiated the Charter of the ITO (known as the Havana Charter), they decided to conclude a provisional agreement that would apply until the ITO came into existence..$^{97}$ To that end, eight nations, including the United States, signed the GATT in October 1947. Negotiations on the Havana Charter wrapped up the following year. ${ }^{98}$ However, objections from both protectionist and free market camps doomed the Charter's hopes for consent from Congress. In December 1950, President Truman quietly withdrew the Charter from congressional consideration. ${ }^{99}$

Instead, the Truman administration pressed ahead with the GATT as its framework for an international trade regime. In doing so, Truman got his multilateral trade agreement despite being unable to secure congressional approval. Truman's actions also created the first major post-war test of Congress's ability to reassert itself in trade policy. Would Congress reclaim primacy, or would it continue to let the President lead, even when his leadership stretched the bounds of his delegated authority?

In the wake of the GATT experience, Congress began experimenting with limits on the President's authority over trade negotiations. For instance, in 1948, immediately after the GATT was signed, Congress inserted a provision into the RTAA requiring the President to furnish the Tariff Commission with a list of products deemed eligible for tariff reductions. The Commission would then

agreements "an important new weapon to advance the cause of freedom" against the communists. IRWIN, supra note 30, at 516, 519, 527.

95. See generally Padideh Ala'i, Transparency and the Expansion of the WTO Mandate, 26 AM. U. INT'L L. REV. 1009 (2011); Ngaire Woods, Bretton Woods Institutions, in THE OXFORD HANDBOOK ON THE UNITED NATIONS (Sam Daws \& Thomas G. Weiss eds., 2008).

96. Id. at 1009 .

97. John H. Jackson, The General Agreement on Tariffs and Trade in United States Domestic Law, 66 MiCH. L. REV. 249, 251-52 (1967).

98. In addition to the tariff reductions, nondiscrimination rules, and limits on nontariff barriers contained in the GATT, the ITO would have included rules on investment, competition, and employment, and established a formal international organization. See STEPHAN W. SCHILL, THE MULTILATERALIZATION OF INTERNATIONAL INVESTMENT LAW 31-60 (2009) (discussing post-World War II efforts to negotiate a multilateral investment regime).

99. Kenneth W. Dam, Cordell Hull, the Reciprocal Trade Agreements Act, and the WTO: An Essay on the Concept of Rights in International Trade, 1 N.Y.U. J. LAW \& BUS. 709, 715 (2005) (discussing Truman's decision to withdraw the ITO Charter from Senate consideration due to protectionist pressures); Zeiler, supra note 91, at 355 (quoting the business community's view that the ITO Charter was an "economic Munich."). 
determine a "peril point" below which rates could not fall without harming domestic producers. ${ }^{100}$ Congress also refused to bless the GATT, stating in each renewal of the RTAA during the 1950s that "[t]he enactment of this Act shall not be construed to determine or indicate the approval or disapproval by the Congress of the Executive Agreement known as the [GATT]." ${ }^{101}$ In another attempt to create an international organization that would oversee the GATT, the Eisenhower administration in 1955 submitted a Draft Charter for the Organization for Trade Cooperation (OTC). Congress never acted on the Charter, and the OTC never came into existence. ${ }^{102}$ However, even these modest limitations (which did not alter the fundamental delegation of tariff authority to the President) ultimately proved too restrictive for the executive branch's foreign policy purposes.

Several years later, Congress passed the Trade Expansion Act of 1962. In proposing the Act, President Kennedy told Congress that its enactment "could well affect the unity of the West, the course of the Cold War, and the growth of our nation for a generation or more to come." 103 The Act substantially expanded the delegation of authority to the President as the United States approached the next round of multilateral trade negotiations (known as the Kennedy Round) by allowing him to reduce tariffs across entire categories of products, rather than on an item-by-item basis, as the RTAA had required ${ }^{104}$ This expansion of authority allowed considerably deeper cuts in tariffs through negotiations with the European Economic Community (EEC), which maintained a single external tariff but lacked the political capacity to negotiate on a line-by-line basis due to its multi-country composition. ${ }^{105}$ Although such authority was limited to

100. Zeiler, supra note 91, at 353. After the Democrats took control of Congress in the 1948 elections, they removed the peril point procedure, although it was reinserted into the RTAA in 1951. Zeiler, supra note 91 , at 359.

101. Trade Agreements Extension Act of June 16, 1951, Public L. 82-50, 65 Stat. 72 (1951); Trade Agreements Extension Act of Aug, 7, 1953, Pub. L. No. 83-215 67 Stat. 472 (1953); Trade Agreements Extension Act of July 1, 1954, Pub. L. No. 883-464, 68 Stat. 360 (1954); Trade Agreements Extension Act of 1955, Pub. L. No. 86, 69 Stat. 162; Trade Agreements Extension Act of Aug. 20, 1958, Pub. L. No. 85-686, 72 Stat. 673 (1958); see also Jackson, supra note 97, at 267.

102. Id. at 265-66.

103. Special Message from President John F. Kennedy to Congress on Foreign Trade Policy 1 (Jan. 25, 1962) (on file with authors) [hereinafter Special Message from Kennedy].

104. Compare "the President may ... proclaim such modification or continuance of any existing duty or other import restriction ... as he determines to be required or appropriate to carry out any such trade agreement," Trade Expansion Act of 1962 § 201(a)(2), 19 U.S.C. § 1821(a)(2) (2017) with "the President... is authorized.... to proclaim such modifications of existing duties and other import restrictions ... of any article covered by foreign trade agreements." Reciprocal Tariff Agreements Act $\S 202(a)(3), 19$ U.S.C. $\S 1351$ (2017).

105. The Act did not permit the President to lower tariff rates to less than 50 percent of their level in 1962. Trade Expansion Act of $1962 \S 201$ (b)(1), 19 U.S.C. § 1821(b)(1) (2017). Congress waived this requirement, though, when "the President determine[d] with respect to [articles in any category] that the United States and all countries of the [EEC] together accounted for 80 percent or more of the aggregated world export value." Id. §211(a), 19 U.S.C. § 1831(a). See also Special Message from Kennedy, supra note 103, at 1-2. 
negotiations with the EEC, the most-favored nation clause in the GATT meant that any concessions made to the EEC were extended to all other GATT parties. ${ }^{106}$

With this expansion of negotiating authority, Congress once again took steps to reign in presidential power. Most significantly, Congress created a Special Trade Representative within the Executive Office of the President and empowered the office-holder to conduct trade negotiations. ${ }^{107}$ Congress's hope was to reduce the influence of general foreign policy concerns on trade policy, in favor of domestic economic policy. ${ }^{108}$

Congress also declined to give the President authority to enter into agreements covering nontariff barriers - a catchall term that includes any governmental measure other than tariffs, such as regulations or trade remedies designed to combat specific instances of unfair trade. As tariffs fell during the successive rounds of GATT negotiations, nontariff barriers became relatively more important impediments to free trade, causing the focus of international negotiations to shift from tariffs to nontariff barriers. Yet reducing nontariff barriers also strikes at the heart of domestic economic concerns. Trade remedies, such as antidumping duties, enable governments to protect specific industries injured by international trade. Although not a major issue for negotiators in the 1960s, environmental or health regulations could restrict trade to the extent that product or production standards differed from country to country.

Despite the absence of authority to negotiate on nontariff barriers, President Johnson did so anyway. The Johnson Administration concluded two such agreements during the Kennedy Round: an Antidumping Code and reforms to how the United States calculated customs values. Lacking statutory authority under the Trade Expansion Act to enter these agreements, the President argued he could enter the Antidumping Code as a sole executive agreement, furthering the notion that the President did not need Congress to make trade policy. ${ }^{109} \mathrm{In}$ retaliation, Congress refused to implement the reforms to the customs valuation process that the President had negotiated. ${ }^{110}$ This failure significantly diminished the administration's credibility in negotiating nontariff barriers - a problem that would only become more central in the 1970s. ${ }^{111}$

The Kennedy Round negotiations laid bare the erratic nature of US trade policy. For the second time since World War II, the President had aggressively

106. Trade Expansion Act of $1962 \S 251,19$ U.S.C. $\S 1881$ (2017).

107. IRWIN, supra note 30, at 526.

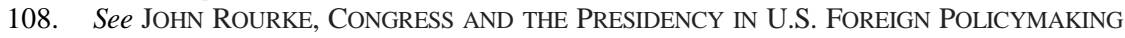
$173(1983)$

109. Koh, supra note 9, at 1199 \& n.23.

110. Id. at 1199 .

111. See Alan F. Holmer \& Judith H. Bello, U.S. Trade and Policy Series No. 20, The Fast Track Debate: A Prescription for Pragmatism, 26 INT'L LAw. 183, 195 (1992) (quoting Sam Gibbons, Chair of the House Subcommittee on International Trade, who said that US negotiators were not trusted after Congress's failure to implement these agreements). 
relied on constitutional and ex ante grants of statutory power to enter into multilateral trade agreements that Congress would not approve, justifying these agreements with reference to larger foreign policy concerns. Rather than proactively assert itself, however, Congress tinkered around the margins of the President's statutory authority while refusing to grant ex post approval for the President's agreements. And while Congress tinkered, international trade negotiations became increasingly concerned with matters beyond simply the tariff - the centerpiece of trade policy since the founding of the Republic. But as discussed below, despite the implications for domestic economic policy, Congress did not take back control of trade policy.

The Trade Act of 1974, passed at the outset of the next round of multilateral trade negotiations (the Tokyo Round), established the framework for contemporary trade policymaking. The 1974 Act included a variety of mechanisms that many have argued represented a reassertion of congressional prerogatives in trade. ${ }^{112}$ Congress had included a consultation and reporting regime in the Trade Expansion Act of 1962, ${ }^{113}$ but in the 1974 Act significantly expanded it to include consultations with the private sector and establishment of associated advisory committees. ${ }^{114}$ The Act also included a legislative veto provision that authorized Congress - via a joint resolution of both houses or in some cases a concurrent resolution of either house - to overturn certain executive branch actions. ${ }^{115}$ For instance, the Act permits American producers to petition the ITC for safeguards - temporary trade barriers imposed to protect American businesses from import competition. ${ }^{116}$ Under the statutory scheme, the Commission makes a recommendation to the President. Pursuant to the legislative veto provision, if the President modifies the recommendation or declines to adopt it, a resolution of both houses of Congress would implement the Commission's recommendation over the President's objection. ${ }^{117}$ Practically speaking, this legislative veto was a tool to force the executive branch to protect American producers. ${ }^{118}$

112. See, e.g., John Linarelli, International Trade Relations and the Separation of Powers Under the United States Constitution, 13 DICK. L. REV. 203 (1995) (arguing that the 1974 Act was a reassertion of congressional power); Lawrence M. Reich, Foreign Policy or Foreign Commerce? WTO Accessions and the U.S. Separation of Powers, 86 GEO. L.J. 751, 756 (1998) (arguing that the 1974 Act was a reassertion of congressional power).

113. Trade Expansion Act of $1962 \S \S 221-223,226 ; 19$ U.S.C. $\S \S 1841-43,1846$ (2017).

114. Trade Act of $1974 \S 135,19$ U.S.C. $\S 2155$ (2017).

115. Id. $\S 152 ; 19$ U.S.C. $\S 2192$.

116. Id. $\S 201$.

117. Id. §203(c).

118. Another notable use of the legislative veto is in Section 301 of the Act. President Trump has relied upon this provision to impose tariffs on $\$ 200$ billion worth of Chinese imports. Section 301 directs the president "to take all appropriate and feasible steps within his power to obtain the elimination of" unjustifiable, unreasonable, or discriminatory actions by foreign governments that burden or restrict US commerce. However, Congress reserved the right to veto the President's chosen action with respect to countries other than the one actually imposing the restriction on US commerce. Id. § 302(b). 
However, the 1974 Act also significantly expanded presidential power in two ways. First, the Act gave the President authority to negotiate agreements reducing nontariff barriers to trade. ${ }^{119}$ Second, Congress agreed to approve such agreements through "fast-track" procedures. Under fast-track, the President could negotiate a trade agreement and then introduce it to Congress, where it received expedited consideration and insulation from the usual amendment process. ${ }^{120}$

Fast-track authority short-circuited congressional review of trade agreements on nontariff barriers relative to the normal legislative process, which applied prior to 1974. As noted above, under the 1962 Trade Expansion Act, the President did not have authority to negotiate nontariff barriers. Consequently, the agreements President Johnson negotiated on nontariff barriers required congressional consent through the ordinary legislative process. Individual members of Congress could thus assert their constituents' interests through amendment procedures. By curtailing that process, fast-track effectively removed the primary vehicle through which local interests could inject themselves into the lawmaking process.

In this way, fast-track authority, while ostensibly giving Congress an ex post say over trade agreements, in fact reduced Congress's role. Prior to 1974, Congress already had an ex post say - it needed to pass legislation to consent to and implement agreements on nontariff barriers. The 1974 Trade Act limited what would otherwise be — and was after the Kennedy Round — plenary review of trade agreements on nontariff barriers. ${ }^{121}$

It is worth dwelling for a moment on how thoroughly Congress failed to assert itself effectively into trade policy-making during this era. First, Congress did not attempt to claw back power when courts found expansive presidential authority in ordinary statutory interpretation cases - even where Congress had not authorized presidential action. For example, in Dames and Moore v. Regan, the Supreme Court upheld the President's authority to settle claims with Iran under the International Emergency Economic Powers Act (IEEPA). ${ }^{122}$ Notably,

119. Id. $\S 102$. 19.

120. Id. $\S \S 102,151$; see also Koh, supra note 9, at 1200-03; Linarelli, supra note 112, at 217-

121. The fast-track procedures were designed to apply to agreements on nontariff barriers, not to tariff reduction commitments, where Congress continued to play primarily an ex ante role. As in prior acts, section 101 of the Trade Act authorized the President to enter into tariff commitments, within defined limits, without any ex post congressional review or approval. Trade Act of $1974 \S 101(\mathrm{~A})(1)$, 19 U.S.C. § 2111 (2017) (providing that the President "may enter into trade agreements with foreign countries or instrumentalities thereof" and modify tariffs accordingly). Section 102 authorized negotiations on nontariff commitments and subjected the resulting agreements to fast-track procedures. Id. § 102 (d), 19 U.S.C. $§ 2112$ (d) ("Whenever the President enters into a trade agreement under this section providing for the harmonization, reduction, or elimination of a barrier to (or other distortion of) international trade, he shall submit such agreement, together with a draft of an implementing bill (described in Section 151(b))"); see also id. § 151(c)(1), 19 U.S.C. § 2191(c)(1) (“"o]n the day on which a trade agreement is submitted to the House of Representatives and the Senate under section 102").

122. Dames and Moore v. Regan, 453 U.S. 654 (1981). 
the Court found that Congress had not authorized the taking of claims under the act. Still, the atmospherics of the statute, which delegated expansive authority to the President over economics in the foreign affairs realm, were sufficient to authorize presidential action (in spite of Congress's express Article I power to regulate foreign commerce). In another case, United States v. Yoshida, the Court of Customs and Patent Appeals found that the Tariff Expansion Act of 1962 neither authorized a presidential proclamation establishing a 10 percent import duty on all items nor granted the President any constitutional commerce powers. At the same time, the court found that the Trading with the Enemy Act did authorize the proclamation because the US balance of payments deficit constituted a national emergency to which the President was responding. ${ }^{123}$ In short, during this era of foreign relations exceptionalism, courts were willing to find expansive presidential power over foreign affairs in statutory cases, and Congress was loathe to intervene.

Second, a variety of congressional actions were largely agnostic on the rise of presidential trade powers - or simply ineffectual in checking that rise. For example, Congress could have passed legislation to authorize GATT or require the United States to withdraw from it. Instead, when Congress renewed trade negotiation authorities in the 1950s, it made an explicit point of noting that it was not acting in either direction on the multilateral trade regime. ${ }^{124}$ Similarly, consultation requirements under the 1974 Trade Act were largely toothless. Not only did ex ante and ongoing consultations leave the President in the driver's seat on substantive negotiations, but the inclusion of fast-track authority left Congress with no ability to amend the domestic bill implementing the trade agreement: lawmakers could either accept the President's deal or reject it wholesale.

Some commentators have argued that Congress's most important attempt to rein in rising presidential power over trade was the use of the legislative veto. ${ }^{125}$ As noted above, alongside the significant delegation of power to the President and the creation of fast-track authority, the 1974 Trade Act included a legislative veto provision giving Congress a check on some of the President's authorities under the Act. ${ }^{126}$ In INS v. Chadha, however, the Supreme Court

123. United States v. Yoshida, 526 F. 2d 560, 580 (CCPA 1975). For a discussion of this case, see Theresa Wilson, Who Controls International Trade? Congressional Delegation of the Foreign Commerce Power, 47 DRAKE L. REV. 141, 157-59 (1998).

124. The provision stated, "[t]he enactment of this Act shall not be construed to determine or indicate the approval or disapproval by the Congress of the Executive Agreement known as the General Agreement on Tariffs and Trade," and was included in the 1951, 1953, 1955, and 1958 extensions. Linarelli, supra note 112, at 214; IRWIN, supra note 30, at 516.

125. Hathaway, supra note 10, at 194 ("In eliminating the legislative veto, the Court eliminated the single most significant control over ex ante congressional-executive agreements that Congress possessed.").

126. Trade Act of $1974 \S \S 152,203(c), 302(b), 402(d), 407,19$ U.S.C. $\S \S 2253(c), 2412(b)$, 2432, 2437 (2018). 
struck down the legislative veto as unconstitutional. ${ }^{127}$ In dissent, Justice White recognized that the Court's decision would eliminate legislative veto provisions in trade, emergency powers, and foreign affairs. ${ }^{128}$ Some have argued that Chadha left Congress without the most important tool it had to control presidential actions in the trade context. ${ }^{129}$

We think this argument does not comport with how trade law intersected with Chadha. The legislative veto in the 1974 Act was not overarching; it did not apply to the President's general delegated tariff-setting powers. Instead it was far narrower, limited to a few particular powers. The narrowness of this power suggests that Chadha did not have as extraordinary an impact on shifting power from Congress to the President as some have thought. Congress's own abdication of its powers, not the Court's decision in Chadha, caused the shift. ${ }^{130}$

Other commentators have suggested that "Chadha will not seriously diminish Congress' influence over trade policymaking" because Congress reasserted itself vis-à-vis the President in a variety of ways during the 1970s and 1980s. ${ }^{131}$ Here, too, we disagree. In practice, Congress's creation of a Trade Representative, delegation of substantive economic policymaking through the Tariff Acts, and authorization to regulate tariffs and trade away non-tariff barriers, concentrated expertise and authority in the President. Moreover, this assembly of power came without the tools of congressional oversight and influence that accompany traditional administrative delegations. ${ }^{132}$ The President's negotiating positions were not, for instance, subject to ordinary notice and comment or judicial review, despite having the force of law once a trade agreement came into effect. ${ }^{133}$ Fast-track was the culmination of this trend.

127. INS v. Chadha, 462 U.S. 919 (1983).

128. Chadha, 462 U.S. at 945, 1003-13 (White, J., dissenting).

129. Hathaway, supra note 10, at 194.

130. Similarly, the legislative veto applied to section 301 of the 1974 Trade Act, which directed the president to "take all appropriate and feasible steps within his power to obtain the elimination of" restrictions "which impair the value of trade commitments made to the United States." Unlike the GATT dispute process, which contemplated a multilateral determination that a government was violating its trade commitments, Section 301 famously authorized the president to make and act upon such determinations unilaterally and as a matter of federal law. However, the statute did not mandate that the president take any particular actions, preferring instead to give the president broad discretion to determine the appropriate actions. 1974 Trade Act $\S 301(a)-(b), 19$ U.S.C. $\$ 2411(a)-(b)$ (The President ... may suspend, withdraw, or prevent ... and may impose duties or other import restrictions) (emphasis added).

131. Koh, supra note 9, at 1192 ("I conclude that, because the legislative veto was only one of a broad array of oversight devices developed by Congress to assert and retain influence in the international trade field, its death in Chadha will not seriously diminish Congress' influence over trade policymaking. To the contrary, recent U.S. trade actions... strongly suggest... an expansion, rather than a contraction, of congressional involvement in trade matters, particularly in two key areas: negotiating authority and import relief.").

132. For an overview of Congress's normal authorities, see Jack M. Beerman, Congressional Administration, 43 SAN DIEGO L. REV. 61 (2006).

133. Beginning with the 1974 Trade Act, however, Congress did subject the President's application of domestic trade remedies laws (designed to provide relief from unfair foreign competition to specific industries or enterprises) to increased judicial review. See Koh, supra note 9, at 1205-06. 
While Congress would have ex ante input into the United States' negotiating position, economic policy enacted through trade agreements - unlike ordinary domestic economic policy-would receive little more than a yes or no from Congress. ${ }^{134}$ In other words, the so-called reforms of the 1970s struck a compromise between active congressional involvement and presidential ability to efficiently negotiate trade agreements. But the compromise was to reduce congressional involvement relative to what prevailed prior to 1974 , not to expand it.

Beyond the formulation of trade law, the President also enjoyed extraordinary freedom from congressional control in the implementation of the international aspects of trade agreements. ${ }^{135}$ As previously noted, the failure of the Havana Charter and the rejection of the Organization for Trade Cooperation rendered the GATT a treaty without an organization. Over time, though, GATT member countries created an institutional apparatus to support GATT implementation. The GATT Council, consisting of member states (represented by their trade ministries), oversaw GATT implementation and served as a forum for negotiations among states. Pursuant to Article XXV of the GATT, members could make "decisions" that at least had the status of soft law and arguably had the status of binding law. ${ }^{136}$ Indeed, four agreements that emerged from the Tokyo Round in 1979, including rules permitting trade preferences for developing countries, were adopted in this way. ${ }^{137}$ Because these decisions are made by an international body - decisions by international bodies have no clear status in US domestic law- the executive branch could agree to the obligations without congressional consent. ${ }^{138}$

The GATT parties also made decisions allowing new members to join, a process that further expanded presidential power. Only twenty-three nations initially signed the GATT in $1947 .{ }^{139}$ By 1975 , however, the GATT had eighty-

134. Adkins \& Grewal, supra note 9, at 1511 (noting that fast-track and the inclusion of nontariff barriers in the domestic regulations arena expanded executive power).

135. As noted above, Congress did try to constrain the President's authority over the application of domestic trade remedies laws. See Trade Act of $1974 \S \S 152$, 203(c), 302(b), 402(d), 407, 19 U.S.C. $\S \S 2253(\mathrm{c}), 2412$ (b), 2432, 2437 (2018); Koh, supra note 9, at 1205-06.

136. General Agreement on Tariffs and Trade, Oct. 30, 1947, 61 Stat. A-11, 55 U.N.T.S. 194, art. XXV [hereinafter GATT]; Timothy Meyer, From Contract to Legislation: The Logic of Modern International Lawmaking, 14 CHI. J. INT'L L. 559, 608 (2014) (arguing that international institutions can use soft law decisions as an alternative to submitting agreements to ratification); John H. Jackson, JeanVictor Louis \& Mitsuo Matsushita, Implementing the Tokyo Round: Legal Aspects of Changing International Economic Rules, 81 MicH. L. REV. 267, 272 (1982) (“The 'understandings' of the 'Group Framework' negotiations were adopted by the GATT Contracting Parties as 'decisions.' The relationship of these agreements and decisions to the GATT itself is not a simple subject").

137. Jackson, Louis \& Matsushita, supra note 136, at 272, 276-77 (noting that four “arrangements" were adopted as "understandings," rather than as standalone agreements).

138. Cf. Jean Galbraith \& David Zaring, Soft Law as Foreign Relations Law, 99 CORNELL L. REV. 735 (2014) (giving examples of executive negotiated international agreements that serve as "soft law").

139. The 128 countries that had signed the GATT by 1994, WORLD TRADE ORG. https://www.wto.org/english/thewto_e/gattmem_e.htm [https://perma.cc/ZKH2-XH7E]; Dale Story, 
two parties. ${ }^{140}$ As a matter of international law, when a new party joined the GATT, it was entitled to receive the benefits of all GATT rules, most notably the tariff rates that the United States (and all other GATT parties) charged every other GATT party pursuant to the most-favored nation obligation. ${ }^{141}$ As a result, expanding GATT membership created new international law limits on US tariffs, as well as limits on the extent to which the United States could discriminate more generally against foreign products. Yet, technically, the United States did not itself make new treaty commitments when new countries joined the GATT. Instead, it simply extended existing commitments. While Congress had authorized ex ante this extension of nondiscriminatory treatment, ${ }^{142}$ it had no formal role in approving new GATT members accepted by the executive branch.

Dispute resolution under the GATT also kept the President in the driver's seat. GATT parties developed the practice of submitting disputes to a panel of experts, which would issue a report to the GATT Council. That report had no legal effect unless the GATT parties, acting through the Council, agreed to adopt it. ${ }^{143}$ The President, through his agents, represented the United States in the GATT Council and, significantly, chose which GATT disputes to bring and how to defend the United States in GATT cases brought against it. Losing a GATT case created pressure on the United States (or any party) to change its trade policies. For instance, in 1976 a GATT panel issued a report finding that US tax legislation creating the Domestic International Sales Corporation (DISC), a tax avoidance vehicle for US exporters, violated GATT rules. ${ }^{144}$ The United States was prepared to allow (and eventually did allow) the GATT Council to adopt the ruling against the United States, and hence conceded that the DISC legislation violated the GATT, even before it knew whether Congress would repeal the legislation. ${ }^{145}$ Such a concession could have provided the basis for trade sanctions against the United States, thereby allowing the executive branch to enlist (or at least acquiesce in) other countries pressuring Congress to repeal legislation.

$* * *$

Trade Politics in the Third World: A Case Study of the Mexican GATT Decision, 36 INT'L ORG. 767, 768 (1982) (noting that twenty-three nations initially signed the GATT).

140. Id.

141. GATT, supra note 136, art. I.

142. See Trade Expansion Act of $1962 \S 251$, 19 U.S.C. $\$ 1881$ (2017); Trade Act of $1974 \S 126$, 19 U.S.C. $\$ 2136$ (2017). In fact, these provisions mandate extending most favored nation treatment to all countries (GATT parties or not), except most notably communist countries. See Trade Act of 1974 $\S 401$.

143. GATT, supra note 136, art. XXIII:2; Robert E. Hudec, Reforming GATT Adjudication Procedures: The Lessons of the DISC Case, 72 MiNN. L. REV. 1443, 1489 (1988) ("The rulings of GATT panels are not binding legal interpretations; they are merely reports to the GATT Contracting Parties or to its agent, the GATT Council, which alone have the power to make authoritative rulings.").

144. Id. at 1488.

145. Id. at 1488-92. 
By the late twentieth century, the foreign affairs paradigm was largely dominant. The President exercised expansive power over trade policy with little meaningful pushback from Congress. At the same time, however, the foreign affairs paradigm became increasingly disconnected from economic realities on the ground. As early as the 1960s, Western Europe and Japan had reentered the export market, and by the 1970s, the "Asian Tigers" were asserting themselves in international markets. ${ }^{146}$ In July 1971, a report of the Commission on International Trade and Investment Policy (Williams Commission) warned that there was "increasing concern that the foreign economic policy of our government has given insufficient weight to our economic interests and too much weight to our foreign policy relations." 147 That same year, the United States ran its first trade deficit since 1935 and saw rising unemployment numbers. ${ }^{148}$ Perversely, at the very moment that economic conditions were changing from the unique moment of the postwar era, the paradigm for trade law and policy became even less tethered to domestic economics.

\section{The Liberalization Era and the Separation of Powers}

Beginning in the 1980s and accelerating with the end of the Cold War, the United States entered a third period marked by domestic economic insecurity and increasing contestation of the foreign affairs paradigm. In this period, the chief goal of trade liberalization has been wealth maximization. Freer trade, proponents argue, increases aggregate national wealth. Although sometimes framed as a domestic economic concern and sometimes as a foreign policy concern, this justification makes comparatively little reference both to the distributional considerations at the core of the domestic economics paradigm and, for the most part, to the specific foreign policy or national security objectives central to the foreign affairs paradigm. Indeed, the liberalization motive was so strong that it might have been a third paradigm for trade and the separation of powers, had it been coupled with its own approach to the allocation of constitutional powers. ${ }^{149}$

The subject matter of trade agreements has also expanded enormously. Agreements now regulate a host of nontariff issues over which Congress and the states have primary constitutional authority. Trade policy also diverged into two tracks: a multilateral track that resulted in the creation of the WTO, and a "mini-

146. Charles Maier, 'Malaise': The Crisis of the Capitalism in the 1970s, in THE SHOCK OF THE GLOBAL: THE 1970S IN PERSPECTIVE 45 (Niall Ferguson et al. eds., 2010); IRWIN, supra note 30, at 509.

147. IRWIN, supra note 30, at 539.

148. Maier, supra note 146, at 45; see also IRWIN, supra note 30, at 539-40.

149. One might argue that it did have such an institutional theory: removal of economic policymaking from domestic politics altogether. Quinn Slobodian, for example, argues that neoliberalism's aim was to entrench economic policy-making in international institutions to insulate it from domestic politics. See Quinn Slobodian, Globalists: The End of EMPIRE AND the BIRTH of NEOLIBERALISM (2018). 
lateral" track that relied on free trade agreements (FTAs) with individual partners or small groups of nations.

Finally, despite the expansion of trade agreements, the executive branch has remained the functional home for trade policy. But Congress, responding to domestic economic insecurity, has increasingly balked at new trade agreements. By the Obama administration, foreign policy considerations had largely become a pretext for trade agreements, while domestic economic considerations had become a roadblock to further trade liberalization — but not a force affirmatively shaping trade policy.

\section{Institution Building at the End of the Cold War}

Initially, both the President and Congress seemed pleased with the 1974 Trade Act framework. In 1979, at the conclusion of the Tokyo Round of GATT negotiations, President Carter submitted a series of agreements on nontariff barriers to Congress. Congress duly approved them in the 1979 Trade Agreements Act, passed pursuant to the fast-track procedures laid out in the 1974 Trade Act. ${ }^{150}$ Moreover, the 1979 statute extended the President's authority to negotiate agreements reducing nontariff barriers-first granted in the 1974 Act for only five years - for an additional eight years. ${ }^{151}$

By the mid-1980s, however, cracks in the foreign affairs paradigm began to show. The trade surpluses that had allowed elected officials to justify using trade policy as a foreign policy tool were long gone by the 1980s, and Congress had become concerned with the global competitiveness of the American economy. ${ }^{152}$ In a move that would foreshadow current trade politics, Congress attempted to push the executive branch to be more aggressive in protecting the American economy and American workers specifically. ${ }^{153}$ In 1985, the House of Representatives began holding hearings, and by 1987 both houses of Congress passed bills. ${ }^{154}$ Although largely forgotten today, some of the proposals considered by Congress, such as mandating presidential concern with trade deficits, were so extreme that President Ronald Reagan referred to them as the "Sons of Smoot-Hawley." 155

150. Jackson, Louis, \& Matsushita, supra note 136, at 365-73 (describing congressional approval of the Tokyo Round Agreements). Indeed, negotiations had not quite finished when Congress enacted the 1979 Trade Agreements Act, yet Congress granted the President authority to enter into the agreements so long as any subsequent changes to the text of the agreements were minor. See Trade Agreements Act of 1979 § 2(b)(1), 19 U.S.C. § 2503(b)(1) (2017).

151. Trade Agreements Act of $1979 \S 1101$.

152. Trade surpluses and deficits are regularly invoked by politicians in justifying trade policies, despite the fact that economists generally argue that these numbers by themselves are not significant. This may be because politicians use them as a proxy for distributional concerns.

153. David E. Birenbaum, The Omnibus Trade Act of 1988: Trade Law Dialectics, 10 U. PA. J. INT'L BUS. L. 653, 656 (1989).

154. Id. at 653 .

155. Id. 
But if the 1988 Act originated in a Congressional desire to reassert itself, the final statute fell far short of that aim. Like earlier statutes, the 1988 Act gave the President authority to enter into tariff agreements and negotiate nontariff agreements that would receive an up or down vote pursuant to fast-track procedures. ${ }^{156}$ The statute did direct the President to negotiate in light of concerns about American competitiveness, but it did so by authorizing the President to negotiate the expansion of the GATT into what became the WTO during the so-called Uruguay Round of negotiations. ${ }^{157}$

The Uruguay Round had three major objectives. First, it aimed to extend the reductions in nontariff barriers negotiated in the Tokyo Round. Second, the United States wished to introduce comprehensive multilateral rules governing trade in services and intellectual property. Up until that point, GATT rules had dealt almost exclusively with trade in goods. Third, the United States aimed to reform the GATT disputes process so that countries, most notably European nations, could no longer impede the adoption of decisions. In its broad goals, the Uruguay Round sought to significantly liberalize trade, an objective the United States pursued within a domestic framework that conferred more power on the executive.

At the same time, congressional efforts to check these presidential powers were limited to a series of nudges. The Act, for instance, required a wide range of new reporting requirements, such as reports on American trade lost to trade barriers, compliance with subsidies rules, and reports from the Treasury on exchange rate policies. ${ }^{158}$ Likewise, Congress toyed with the idea of requiring the US Trade Representative to retaliate for restrictions on US market access and violations of trade agreements. Instead, Congress ultimately built in a series of discretionary mechanisms giving the executive the power to initiate an investigation into restrictions adversely impacting the United States and to waive sanctions for violating trade agreements. ${ }^{159}$

The 1988 Act ultimately provided the domestic legal basis for two of the most significant — and controversial — trade agreements in American history: the Marrakech Agreement (creating the WTO) and NAFTA. Coming at the end of the Cold War, both agreements represented a pivot from Cold War politics to the international institution building that would characterize the 1990s. Beyond greatly expanding international trade rules (and in the case of NAFTA providing the basis for supply chains to disaggregate across North America), these two agreements also legalized international trade law to a degree previously unknown in any area of international law. The WTO's Dispute Settlement Understanding (DSU) established a disputes process with an appellate

156. Omnibus Foreign Trade and Competitiveness Act of 1988 § 1102-03, 19 U.S.C. $\S 2902-$ 2903 (2018).

157. Omnibus Foreign Trade and Competitiveness Act of 1988 § 1101, 19 U.S.C. $§ 2901$.

158. Birenbaum, supra note 153, at 656.

159. Id. at 657 . 
mechanism and automatic adoption of reports. ${ }^{160}$ No longer would reluctant countries or losing parties be able to block the legal effect of adverse rulings. At the same time, the DSU also removed the ability of nations to act unilaterally in response to trade violations. Instead, nations must first seek approval from the WTO's Dispute Settlement Body (DSB). ${ }^{161}$

The DSU revitalized the GATT/WTO dispute settlement process, which has emerged as the most successful standing international dispute body ever. ${ }^{162}$ At the same time, however, it further empowered the President at the expense of Congress. The President represents the United States in disputes before the WTO and therefore controls the United States' litigating position. The ban on unilateral action also removed the possibility that Congress could directly legislate retaliation against foreign countries without running afoul of WTO rules. Indeed, in a case brought by the European Union (EU) shortly after the WTO came into force, the United States conceded that it would no longer invoke its unilateral authority to retaliate under Section 301 of the 1974 Act, even though Congress had not amended the Act's mandate that the President take action to respond to violations of trade commitments. ${ }^{163}$

With relatively little fanfare, Congress passed the Uruguay Round Agreements Act (URAA) in 1994 to implement the WTO agreements. Since then, WTO members have not completed a major package of trade liberalization commitments. The so-called Doha Round, which began in 2001, has yielded little in terms of concrete results and has repeatedly been pronounced dead. Given this failure, it is perhaps surprising that trade liberalization via the WTO continued apace through the end of the Clinton administration and into the Bush administration. The accession of new members to the WTO provided new markets for US businesses abroad and entitled those nations to the most-favored nation commitments the United States had already made at the WTO. China's accession in 2001 was by far the most important in terms of effects on the US economy. Recent economic studies have found that China's accession-and the related decline in tariffs on Chinese products - has had a considerably more important effect on the American economy and on the loss of American manufacturing jobs than joining NAFTA did. ${ }^{164}$

160. Understanding on Rules and Procedures Governing the Settlement of Disputes art. 1, Apr. 15, 1994, Marrakesh Agreement Establishing the World Trade Organization, Annex 2, 1869 U.N.T.S. 401, art. 17 [hereinafter DSU].

161. Id., art. 23.

162. The DSB has entertained over 500 disputes since January 1, 1995, with a high degree of compliance from nations. See WTO Dispute Settlement Gateway, WORLD TRADE ORG., https://www.wto.org/english/tratop_e/dispu_e/dispu_status_e.htm [https://perma.cc/9KGB-J24X]. By contrast, the International Criminal Court, which came into existence in 2001, has managed to complete only a handful of trials over approximately the same period.

163. Panel Report, United States-Section 301-310 of the Trade Act 1974, WTO Doc. WT/DS152/AB (adopted Feb. 28, 2000).

164. See David H. Autor, David Dorn \& Gordon H. Hanson, The China Syndrome: Local Labor Market Effects of Import Competition in the United States, 103 AM. ECON. REV. 2121, 2125 (2013) 
Despite the importance of permitting China to join the WTO, Congress had no formal approval over Chinese accession. Similar to the GATT process, existing members voted to approve new members, and the executive branch controlled the United States' vote. The URAA requires the President to consult with Congress prior to WTO votes on the adoption of decisions or on the acceptance of new members if the action in question "would substantially affect the rights or obligations of the United States ... or potentially entail[] a change in Federal or State law." 165 Unlike with new trade agreements, though, Congress does not need to vote either on accepting new members or on the package of concessions the executive branch (and other nations) negotiated as the cost of permitting the new member to join. ${ }^{166}$ Membership in international organizations like the WTO is treated as a foreign policy issue subject to the discretion of the executive branch. ${ }^{167}$

The result of the 1988 Act and the Uruguay Round was to shift more power to the executive branch and further unhook trade policy from both the domestic economic and foreign affairs paradigms that had long characterized trade's role within the separation of powers. Rather than accounting for the economic interests of diverse US constituencies or advancing specific foreign policy and national security aims, the WTO accession process enabled further liberalization for its own sake. ${ }^{168}$

("We find that local labor markets that are exposed to rising low-income-country imports due to China's rising competitiveness experience increased unemployment, decreased labor-force participation, and increased use of disability and other transfer benefits, as well as lower wages."); see also Justin R. Pierce \& Peter K. Schott, The Surprisingly Swift Decline of U.S. Manufacturing Employment, 106 AM. ECON. REV. 1632 (2016) (linking a drop in US manufacturing jobs after 2000 to limitations on increasing tariffs against Chinese goods, with industries more exposed to the policy change suffering greater declines in employment).

165. URAA § 122(b), 19 U.S.C. § 3532 (2017).

166. Congress entertained a number of bills that would have limited the executive branch's freedom to support Chinese accession to the WTO, although none of these bills were ever enacted. See Alan S. Alexandroff, Concluding China's Accession to the WTO: The U.S. Congress and Permanent Most Favored Nation Status for China, 3 UCLA J. INT'L \& FOREIGN AFF. 23, 34-38 (1998).

167. Congress did have to vote on extending MFN status to China. Prior trade statutes had withheld that status from Communist countries, and to allow China to join the WTO without MFN status would have put the United States into breach of its WTO obligations to China. See id; Trade Act of 1974 $\S 401$ (mandating that the "President shall continue to deny nondiscriminatory treatment to the products of any country" deemed ineligible). Hence, US law created an odd situation: the president had unchecked authority (as a matter of federal law) to support Chinese accession and determine the conditions thereof, but Congress would need to act to avoid the United States becoming subject to trade sanctions. See Nicholas R. Lardy, Permanent Normal Trade Relations for China, BROOKINGS INST. (May 10, 2000). In late 2000, Congress did indeed extend MFN status to China without any strings, although it created a series of monitoring mechanisms to oversee Chinese compliance with its WTO commitments. Act of Oct. 10, 2000, Pub. L. No. 106-286, 114 Stat. 880 (2000) (establishing normal trade relations between the U.S. and China).

168. While there is an argument that further liberalization enhances foreign policy goals or benefits the domestic economy, our point is that these broad justifications are indirect and disconnected from legal processes that one might expect, under our constitutional system, to vindicate those goals. 


\section{The Turn Toward Free Trade Agreements (FTAs)}

Although other countries have continued to join the WTO (most notably Russia in 2012), the WTO in the twenty-first century largely became a dispute resolution forum. ${ }^{169}$ As such, trade liberalization commitments through the WTO have become almost entirely an executive affair. The executive negotiates and votes on the expansion of the WTO to new members and conducts trade litigation - which can affect the United States' obligations - on behalf of the United States with relatively little activity required by Congress. ${ }^{170}$ While WTO expansion can integrate new markets and litigation can develop and clarify existing rules, the stalemate in the Doha Round means the WTO cannot develop new rules. Instead, FTAs have replaced the multilateral system as the primary forum for trade negotiations over new rules. This turn toward FTAs, more than any other development, has unmoored trade policy from traditional foreign policy concerns. Although some relatively minor FTAs have been used to reward allies, the most significant FTAs have been justified on the grounds that they allow economic integration to proceed faster than the glacial pace truly multilateral negotiations permit.

To accomplish this integration, FTAs are often far more comprehensive in scope than WTO agreements, including, for instance, rules on investment and the digital economy and data. ${ }^{171}$ Beyond coverage, FTAs usually also liberalize trade in goods and services beyond what WTO rules require. An exception in WTO rules to the most-favored nation obligation permits this preferential treatment, provided that nations eliminate "substantially all" barriers to trade between them. ${ }^{172}$ Consequently, FTA parties eliminate a considerably wider range of trade barriers than WTO rules require.

Many chapters of FTAs themselves contain most-favored nation clauses. These clauses usually require that members of the FTA be accorded treatment that is "no less favourable" than that accorded to "any other Party or a nonParty." 173 This means that, as a general matter, the United States must extend any preferential treatment it provides to a subsequent FTA partner to all existing FTA partners. For example, if South Korea receives preferential treatment in the services sector via its FTA with the United States that entered into force in 2012, Mexico and Canada would be entitled to the same treatment by virtue of the

169. Even that role is in peril as of the time of writing. The Trump administration has blocked the appointment of new Appellate Body members, causing the Appellate Body's membership to fall below the minimum necessary to hear many cases.

170. We discuss the impact of this litigation below. See infra Part III.

171. See, e.g., North American Free Trade Agreement, U.S.-Can.-Mex., Dec. 17, 1992, 32 I.L.M. 289 (1993) (establishing rules on investment) [hereinafter NAFTA]; Trans-Pacific Partnership ch. 14, Feb. 4, 2016, https://ustr.gov/trade-agreements/free-trade-agreements/trans-pacific-partnership/tpp-fulltext (establishing rules governing electronic commerce) [hereinafter TPP].

172. See GATT, supra note 136, art. XXIV; General Agreement on Trade in Services, Jan. 1, 1995, 1869 U.N.T.S. 183, 33 I.L.M. 1167, art. V [hereinafter GATS].

173. TPP, supra note 171, art. 10.4 (in the services chapter); NAFTA, supra note 171, art. 1203 (same). 
most-favored nation clause in the services chapter of NAFTA, which entered into force in 1994. As a result of these clauses, FTAs form a multilateral web of trade liberalization commitments.

This web undermines the foreign policy rationales for FTAs. If an FTA is meant to reward an ally for support on issues such as military and geopolitical support-as opposed to representing an equal trade between parties of market access concessions - that ally does not necessarily need the protection of a clause that gives it the benefits from all future US FTAs. Indeed, granting such allies the benefits of future FTAs risks disrupting the American economy with no offsetting benefit in the form of meaningful market access concessions to the United States. ${ }^{174}$

Ironically, given that many FTAs are largely detached from foreign policy concerns, the US turn to FTAs came about because of efforts to pursue one of the United States' most bipartisan foreign policy objectives: a strong relationship with Israel. In 1983, President Reagan and Israeli President Yitzhak Shamir announced their intention to negotiate a free trade agreement. ${ }^{175}$ That agreement, entered into in 1985, was the United States' first comprehensive FTA. ${ }^{176}$ Given the modest size of the Israeli economy, the economic effects of the agreement on the American economy were negligible. Nevertheless, this foreign policyoriented trade agreement laid the groundwork for a US program of negotiating FTAs.

Today, the United States is party to fourteen FTAs in force with twenty different countries. ${ }^{177}$ Additionally, in 2016 the United States signed the twelvenation TPP, a comprehensive FTA that blanketed the Pacific Rim. The United States has also pursued an FTA with the European Union known as the TransAtlantic Trade and Investment Partnership (T-TIP). ${ }^{178}$

The Israeli-US negotiations presented an odd problem. Although the President continued to have authority to negotiate reductions in nontariff barriers, Congress had declined in the 1979 Trade Agreements Act to extend his authority to negotiate tariff reduction commitments. ${ }^{179}$ As a consequence, the President could not negotiate an FTA without Congress revisiting his negotiating

174. It is not clear that this approach can be justified on domestic economic grounds either. The only context in which this approach would be justified is if liberalization is always domestically beneficial. This point, of course, is contested, particularly on distributional grounds, by many of the domestic economic interests that supposedly benefit.

175. Koh, supra note 9, at 1211.

176. Id. at $1211 \&$ n.57.

177. Office of the United States Trade Representative, Free Trade Agreements, EXEC. OFFICE OF THE PRESIDENT, https://ustr.gov/trade-agreements/free-trade-agreements [https://perma.cc/MVC8ZY4R].

178. Id. In 2017, President Trump announced his intention not to proceed with the TPP. Peter Baker, Trump Abandons Trans-Pacific Partnership, Obama's Signature Trade Deal, N.Y. TIMES (Jan. 23, 2017), https://www.nytimes.com/2017/01/23/us/politics/tpp-trump-trade-nafta.html [https://perma.cc/Q3MB-E9AG].

179. Trade Agreements Act of $1979 \S 1101,19$ U.S.C. $§ 2902$ (2018). 
authority. To address this problem, Congress passed the 1984 Trade and Tariff Act. ${ }^{180}$ Beyond expressly authorizing the FTA negotiations with Israel, the 1984 Act made two other changes that would have far-reaching consequences.

First, the Act expanded the definition of "international trade" to include foreign investment. ${ }^{181}$ The 1974 Act had limited the definition to trade in goods and services. ${ }^{182}$ This expanded mandate allowed the President to negotiate investment chapters in US FTAs, even though the multilateral GATT did not include rules on investment. The executive branch thus had broader scope to negotiate economic liberalization.

Second, the 1984 Act established a procedure for the President to negotiate FTAs with countries other than Israel that would be eligible for modified fasttrack approval. ${ }^{183}$ Specifically, the Act provided that if a country other than Israel requested FTA negotiations with the United States, the President must notify the Senate Finance Committee and the House Ways and Means Committee sixty days in advance of notifying the full Congress of his intention to enter into the agreement. ${ }^{184}$ If either committee disapproved of the negotiations, any resulting agreement would not be eligible for fast-track procedures. ${ }^{185}$ The availability of fast-track procedures for FTAs put bilateral or mini-lateral negotiations on the same footing as multilateral GATT negotiations. ${ }^{186}$ At the same time, bilateral negotiations could be completed much more quickly, precisely because of the smaller number of parties.

As a result of the President's expanded authorities and the ease of negotiating in smaller groups, FTAs quickly became the preferred tool for negotiating new trade agreements. In 1985, President Reagan notified the Senate Finance and the House Ways and Means Committees of his intention to negotiate an FTA with Canada. ${ }^{187}$ The US-Canada Free Trade Agreement, in turn,

180. See generally Trade and Tariff Act of 1984, Pub. L. No. 573 (providing bilateral trade negotiating authority with Israel).

181. Trade and Tariff Act of $1984 \S 307$.

182. Trade Act of $1974 \S 102(\mathrm{~g}), 19$ U.S.C. $\S 2112$ (2018).

183. Koh, supra note 9, at 1212-13.

184. Trade and Tariff Act of $1984 \S 401$ (a)(2).

185. Because fast-track procedures are merely legislative procedures, this form of legislative veto does not violate the letter of Chadha, which focuses on whether a legislative veto alters legal entitlements. See Koh, supra note 9, at 1216 \& n.77; INS v. Chadha, 462 U.S. 919 (1983).

186. Although it expanded the president's authority to negotiate and made FTAs an attractive alternative to multilateral trade negotiations, the 1984 Act also began divorcing American trade policy from broader foreign policy concerns. By giving the Senate Finance and House Ways and Means Committees the ability to deny FTAs fast-track authority, the Act denied oversight authority to the two congressional committees concerned with foreign policy, the Senate Foreign Relations and House Foreign Affairs Committees. Koh, supra note 9, at 1215. Moreover, by creating a procedure that could eliminate fast-track procedures for negotiations of which these two committees disapproved, the Act also modestly increased Congress's role in approving trade agreements.

187. Id. 
provided the groundwork for NAFTA negotiations when Mexico requested that the bilateral agreement be expanded to include it. ${ }^{188}$

NAFTA's most important feature was that it allowed duty-free entry of goods into the United States from Mexico, a country with considerably lower wages. As a result, many at the time expected a mass migration of American manufacturing jobs to Mexico, where goods could be manufactured cheaply and then reimported into the United States without having to pay a tariff. Almost as important, though, at least for political purposes, NAFTA's investment chapter imported a mechanism known as investor-state dispute settlement (ISDS) into a major trade agreement. ${ }^{189}$ ISDS allows a private investor to bring an arbitration claim for monetary damages directly against a foreign government. ${ }^{190}$ Since NAFTA came into force, the United States has been the respondent in twentyone arbitration cases brought by Mexican and Canadian investors, though it has not yet lost a case. ${ }^{191}$

To be sure, NAFTA did not invent ISDS, a mechanism found in bilateral investment treaties. NAFTA did, however, establish rules governing investment between the United States and its only two adjacent neighbors, one of which is a developed country. Most US bilateral investment treaties are with small developing countries that have little investment in the United States. These treaties are therefore unlikely to ever be the basis for an ISDS claim against the United States. The United States had concluded only a handful of these agreements prior to NAFTA, with countries such as Panama, making NAFTA the first major US agreement to involve rules on investment. ${ }^{192}$

This shift to including investment in trade agreements is important because rules on how a government treats foreign investment are more invasive than mere trade rules. Especially in the 1980s, when the United States negotiated these agreements, trade rules dealt chiefly with barriers at the border. ${ }^{193}$ After a product gains entry into the United States, however, the main requirement imposed by trade rules is that it be treated the same as any other product in the stream of commerce. ${ }^{194}$ Investment agreements, like NAFTA chapter 11, contain

188. Frederick M. Abbott, NAFTA and the Legalization of World Politics: A Case Study, 54 INT'L ORG. 519, 522 (2000).

189. NAFTA, supra note 171 , ch. 11

190. Id. art. 1119.

191. Canada and Mexico have not been so lucky. Mexico has been subject to twenty-four claims, while Canada has been subject to thirty-four claims. Moreover, unlike the United States, both Canada and Mexico have been on losing end of cases, resulting in judgments worth hundreds of millions of dollars. For comprehensive information on NAFTA disputes, see Todd Weiler, NAFTAClaims.com (2015), www.naftaclaims.com/index.html [https://perma.cc/5CV8-UZY5].

192. U.S. Dep't of State, List of U.S. Bilateral Investment Treaties, https://www.state.gov/e/eb/ifd/bit/117402.htm [https://perma.cc/N87J-RQA4].

193. Indeed, even many of the Tokyo Round agreements on nontariff barriers actually dealt with border measures such as antidumping and countervailing duties. See Jackson, Louis, \& Mitsushita, supra note 136 (describing the Tokyo Round agreements). Today, trade regulation of nontariff barriers does involve more regulation of behind-the-border activity.

194. See GATT, supra note 136, art. III. 
nondiscrimination rules too, but they also have rules that establish substantive standards of treatment (roughly akin to due process in US constitutional law). These rules - on "fair and equitable treatment," the minimum standard of treatment, and expropriation ${ }^{195}$ — potentially make a government liable to a private investor if it exercises its regulatory power in a way that either falls below the standard of treatment required by international law or violates the investor's reasonable expectations in a way that impairs the value of the investment. ${ }^{196}$ Combining these rules with a private international remedy created the concern that investment agreements would limit the exercise of state regulatory power to a considerably greater degree than multilateral trade agreements. ${ }^{197}$

The process of approving NAFTA in Congress showed the extraordinary strain on the foreign affairs paradigm. The negotiations had largely been completed in 1992, when President George H.W. Bush was running for reelection. ${ }^{198}$ But in 1992, the Cold War was over, and the United States was emerging from a recession. ${ }^{199}$ Consequently, domestic economic policy became a central issue in the campaign. In a precursor of events to come, billionaire Ross Perot ran for president as a third party anti-trade-liberalization candidate. Perot made a point of attacking President Bush's embrace of NAFTA, famously referring to the "giant sucking sound" that would come as Mexico took American jobs. ${ }^{200}$ Then-Arkansas governor Bill Clinton, the Democratic challenger, took a middle road, calling for NAFTA to proceed only after Mexico and Canada had agreed on tougher rules for environmental and labor standards. ${ }^{201}$ When Clinton won the election and Democrats generally opposed to the agreements retained control of Congress, it seemed like US trade policy might pivot back towards domestic economic concerns.

195. NAFTA, supra note 171 , arts. $1105 \& 1110$.

196. As such, these rules are similar in function to the protections afforded by the due process and takings clauses of the Fifth and Fourteenth Amendments.

197. As we discuss below, this potential has been a potent political force in the United States and, in other countries, has led to regulatory chill, in which governments avoid regulating out of fear of losing an ISDS case and being forced to pay compensation. Indeed, in NAFTA 2018 the Trump administration negotiated the elimination of ISDS for all but a narrow range of cases. See United States-Mexico-Canada Agreement ch. 14, Nov. 30, 2018 [hereinafter USMCA].

198. Indeed, President Bush actually signed NAFTA before he left office. See George Bush, Remarks on Signing the North American Free Trade Agreement (Dec. 17, 1992), http://www.presidency.ucsb.edu/ws/?pid=21784 [https://perma.cc/ULN4-VBXP].

199. Steven Greenhouse, The 1992 Campaign: The Economy; Despite Recession's End, Bush May Face Unusually Harsh Public Judgment, N.Y. TIMES (May 11, 1992), https://www.nytimes.com/1992/05/11/us/1992-campaign-economy-despite-recession-s-end-bushmay-face-unusually-harsh.html [https://perma.cc/manage/create?folder=7093].

200. The 1992 Campaign: Transcript of the $2 d$ Debate between Bush, Clinton, and Perot, N.Y. TIMES (Oct. 16, 1992), https://www.nytimes.com/1992/10/16/us/the-1992-campaign-transcript-of-2dtv-debate-between-bush-clinton-and-perot.html [https://perma.cc/7QP4-6JDG].

201. Gwen Ifill, The 1992 Campaign: The Democrats; With Reservations, Clinton Endorses Free-Trade Pact, N.Y. Times (Oct. 5, 1992), https://www.nytimes.com/1992/10/05/us/1992-campaigndemocrats-with-reservations-clinton-endorses-free-trade-pact.html [https://perma.cc/Q3BL-LYBU]. 
Instead, President Clinton did as he promised, negotiating what are known as the NAFTA Side Agreements on Labor and the Environment (or more formally, the North American Agreements on Environmental and Labor Cooperation). ${ }^{202}$ Congress then passed a bill implementing NAFTA, the NAFTA Implementation Act. This established an unfortunate, and unstable, precedent on how to address the distributional effects of trade liberalization. With the end of the Cold War, domestic economic insecurity had reasserted itself as a political brake on trade liberalization. American presidents, however, chose not to address this problem by designing an international trade policy that responded directly to this insecurity. Instead, their approach reflected two views.

First, the overall benefits to the national economy provided the domestic economic justification for the agreements. ${ }^{203}$ Unlike earlier eras of US trade policy, distributional issues about who in the American economy gained and lost were not directly part of the administration's justifications or goals for its international trade policy. ${ }^{204}$

Second, to assuage concerns in Congress about the domestic economic effects of further trade liberalization, in particular the fear that American manufacturing jobs would move wholesale to Mexico, President Clinton negotiated the NAFTA Side Agreements, which required NAFTA parties to enforce their own domestic environmental and labor laws. ${ }^{205}$ President Clinton sold these agreements on the premise that they would help alleviate the loss of jobs to Mexico by counteracting the lower labor costs in Mexico that stemmed, at least in some part, from less regulation. ${ }^{206}$ In other words, the Clinton administration's approach to domestic labor market concerns raised by trade agreements was to negotiate international obligations to raise standards in Mexico - an outwardly focused approach to solving a fundamentally domestic economic problem. ${ }^{207}$ Although the content of these labor and environment obligations became somewhat stricter in subsequent US trade agreements, the muddled approach of trying to address domestic job losses in the United States by imposing obligations on foreign countries remained. ${ }^{208}$ These obligations

202. See North American Agreement on Environmental Cooperation, opened for signature Sept. 8, 1993, 32 I.L.M. 1480 [hereinafter NAFTA Environmental Side Agreement]; North American Agreement on Labor Cooperation, Sept. 14, 1993, 32 I.L.M. 1499 [hereinafter NAFTA Labor Side Agreement].

203. Timothy Meyer, Saving the Political Consensus in Favor of Free Trade, 70 VAND. L. REV. 985, 992-97 (2017).

204. To be sure, the United States carried forward trade adjustment assistance, a domestic program designed to aid workers displaced by competition with imports. However, trade adjustment assistance as implemented in the United States has been largely ineffective. Id. at 1008-10.

205. NAFTA Environmental Side Agreement, supra note 202, art. 5 ("[E]ach Party shall effectively enforce its environmental laws and regulations through appropriate governmental action....”); NAFTA Labor Side Agreement, supra note 202, art. 3 ("Each Party shall promote compliance with and effectively enforce its labor law....").

206. Meyer, supra note 203, at 1002-04.

207. Id. at 990.

208. Id. at 1004-08. 
have since become standard in US FTAs. ${ }^{209}$ Not surprisingly, these labor and environment provisions have not improved the lot of American workers, creating further cynicism about American trade agreements. ${ }^{210}$

While President Clinton was ultimately successful in winning congressional support for NAFTA, he did so at the cost of the President's negotiating authority. After extending fast-track to allow for the passage of the Uruguay Round Agreements Act, Congress let fast-track authority lapse in 1994. Since that time, Congress has only twice renewed the authority (now called "trade promotion authority"), once in 2002 for a five-year period and again in 2015 for three years. ${ }^{211}$

The first of these renewals came at the request of President George W. Bush. He used the authority to negotiate a series of mostly bilateral FTAs, alongside the Central American Free Trade Agreement (CAFTA). With the exception of the agreement with Korea (the United States-Korea Free Trade Agreement or "KORUS"), which is the United States' sixth largest trading partner, ${ }^{212}$ these agreements had negligible economic impact on the US economy as a whole. Instead, these agreements - completed with countries like Colombia, Jordan, Bahrain, Morocco, and Oman - shored up American interests around the world by rewarding countries that supported the United States during its wars in Afghanistan and Iraq. ${ }^{213}$ Most of these agreements received relatively swift approval from Congress. Those few that did not were approved after Congress reached a new agreement with the administration, known as the May 10th consensus. That agreement required the administration to negotiate provisions in FTAs requiring, among other things, that countries comply with international labor and environmental provisions and subjecting that commitment to ordinary dispute resolution and the possibility of trade sanctions. ${ }^{214}$ While the May 10th consensus did little formally to alter the balance of power between Congress and the President, it demonstrated a renewed resolve on Congress's part to use its

209. Id. at $1003-04$.

210. Id. at 1004-08.

211. The three-year period in the 2015 Bipartisan Trade Priorities and Accountability Act can be extended an additional three years if the President so requests and neither house of Congress passes a resolution vetoing the extension. Bipartisan Trade Priorities and Accountability Act of $2015 \S 103,19$ U.S.C. $\S 4202$ (2018).

212. U.S. Dep't of Commerce, Top U.S. Trade Partners 2016, https://www.trade.gov/mas/ian/build/groups/public/@tg_ian/documents/webcontent/tg_ian_003364.p df [https://perma.cc/2KH7-K2AX].

213. See Office of the U.S. Trade Representative, Free Trade Agreements, EXEC. OfFICE OF THE PRESIDENT, https://ustr.gov/trade-agreements/free-trade-agreements [https://perma.cc/PX3Z-6GAZ] (providing full texts and dates of entry into force for U.S. trade agreements).

214. See Office of the U.S. Trade Representative, Exec. OfFice of the President, TRADE FACTS: BIPARTISAN TRADE DEAL (2007), https://ustr.gov/sites/default/files/uploads/factsheets/2007/asset_upload_file127_11319.pdf [https://perma.cc/9EM9-RHDP]. The agreement also made the "essential security" exception to trade agreements "self-judging," meaning that if a country invoked its essential security interests, other nations could not challenge the exception through dispute resolution. 
authority to force the President to include provisions it deemed important. These provisions, however, continued to be primarily outwardly focused, aiming to improve practices abroad to address economic challenges at home.

Demonstrating a continuity across party lines that has characterized executive trade liberalization efforts since President Truman, President Barack Obama began his administration by obtaining congressional approval for several FTAs negotiated under President Bush. In his second term, President Obama then turned to another Bush-era initiative, the TPP. The TPP would end up being a twelve-nation pact, including the three NAFTA parties, Australia, Chile, Japan, Vietnam, Singapore, Malaysia, Brunei, New Zealand, and Peru. President Obama justified the agreement primarily on foreign policy grounds. The agreement, he claimed, would allow the United States "to write the rules" for the twenty-first century international economy. ${ }^{215}$ In particular, the TPP would encircle China, which had emerged as the second largest national economy in the world. ${ }^{216}$ This justification was especially important politically because the government itself projected that the TPP would have only a modest impact on the overall growth of the US economy - 0.15 percent growth in annual GDP fifteen years into the life of the agreement. ${ }^{217}$

The TPP would face two tests in Congress: granting the President authority to negotiate the agreement and then ultimately approving it. President Obama sought trade promotion authority to spur the agreement's acceptance. Congress gave him that authority in the Bipartisan Trade Priorities and Accountability Act of 2015. That Act, however, revealed a distrust that had grown between Congress and the President. Although Congress maintained the basic framework for trade promotion authority, it limited its effectiveness to three years with a possible three-year extension if the President so requested and neither house of Congress passed a resolution vetoing the extension. ${ }^{218}$ The Act also imposed some of the strictest notification and consultation requirements to date, mandating, for instance, that the Trade Representative meet with any member of Congress "upon request" to discuss the status of negotiations and provide any member of

215. Press Release, White House Office of the Press Sec'y, Remarks by President Obama in Meeting on the Trans-Pacific Partnership (Nov. 18, 2015), https://www.whitehouse.gov/the-pressoffice/2015/11/18/remarks-president-obama-meeting-trans-pacific-partnership [http://perma.cc/2H74HNTJ].

216. China would be third if one counted the EU as a single country. See Int'l Bank for Reconstruction \& Dev., GDP (current US\$), WORLD BANK, https://data.worldbank.org/indicator/NY.GDP.MKTP.CD?year_high_desc=true [https://perma.cc/PE35-2YWK].

217. Press Release, U.S. Int'1 Trade Comm'n, USITC Releases Report Concerning the Likely Impact of the Trans-Pacific Partnership Agreement (May 18, 2016), https://www.usitc.gov/press_room/news_release/2016/er051811597.htm [https://perma.cc/U8TSAUVK]. This modest growth as a percentage still equaled $\$ 42.7$ billion and was projected to be the highest absolute gain among the TPP parties. Peter A. Petri \& Michael G. Plummer, The Economic Effects of the Trans-Pacific Partnership: New Estimates, Peterson Institute for International Economics Working Paper 16-2 (January 2016).

218. Bipartisan Trade Priorities and Accountability Act $\S 103$, 19 U.S.C. $\S 4202$ (2018). 
Congress with relevant documents, including classified material. ${ }^{219}$ The statute also took modest steps towards increasing Congress's oversight role once the agreement entered into force. Specifically, the statute required extensive consultations with Congress regarding not only the steps US trading partners would take to comply with the agreement, ${ }^{220}$ but also any enforcement action the executive branch intended to take. ${ }^{221}$ Congress also put some teeth behind the consultation requirements by providing that both Houses together could revoke an agreement's eligibility for fast-track procedures by passing separate resolutions finding that the President had failed to properly consult. ${ }^{222}$

Ultimately, these provisions and the congressional skepticism behind them were never put to the test. Although President Obama signed the TPP on February 4, 2016, the agreement seemed likely to fail in Congress. ${ }^{223}$ Before Congress had the chance to vote the TPP down, however, electoral politics broke what little remained of the foreign affairs paradigm. Trade was a central issue in the 2016 presidential campaign. Democratic candidate Bernie Sanders and Republican nominee Donald Trump both derided free trade agreements as the cause of an exodus of American manufacturing jobs. This criticism apparently forced the Democratic nominee Hillary Clinton to disavow a trade agreement she had supported as Secretary of State. ${ }^{224}$ Polling data during the election also revealed a collapsing political consensus in favor of free trade. ${ }^{225}$ Notably, one poll found that 67 percent of Trump supporters - and 52 percent of those who vote Republican, the party most likely to favor free trade — had negative views of free trade. ${ }^{226}$

In this environment, an electorate rife with economic insecurity resolved the tension between the President and Congress in favor of slowing trade liberalization. Following Trump's election in November, President Obama

219. Id. § 104(a)(1).

220. Id. § 104(a)(3).

221. Id. § 105(f)(3).

222. Id. § 106(b).

223. Trans Pacific Partnership Trade Deal Signed in Auckland, BBC News (Feb. 4, 2016), http://www.bbc.com/news/business-35480600 [http://perma.cc/FL22-B3XW]; Adam Behsudi, Obama Puts Congress on Notice: TPP is Coming, Politico (Aug. 12, 2016), https://www.politico.com/story/2016/08/obama-congress-trade-warning-226952

[https://perma.cc/C7YN-UL2U] ("But the deal is going nowhere until the White House addresses a number of concerns lawmakers have raised about the trade agreement.").

224. Max Ehrenfreund, How Hillary Clinton's Positions Have Changed as She's Run Against $\begin{array}{llll}\text { Bernie Sanders, WASH. } & \text { PosT 20, }\end{array}$ https://www.washingtonpost.com/news/wonk/wp/2016/04/29/how-hillary-clintons-positions-havechanged-while-running-against-bernie-sanders/?noredirect=on\&utm_term=.25ec 32099753 .

225. See Meyer, supra note 206, at 997-98.

226. Bruce Stokes, Republicans, Especially Trump Supporters, See Free Trade Deals as Bad for U.S., PEW RES. CTR.: FACTTANK (Mar. 31, 2016), http://www.pewresearch.org/fact$\operatorname{tank} / 2016 / 03 / 31 /$ republicans-especially-trump-supporters-see-free-trade-deals-as-bad-for-u-s [https://perma.cc/9RSL-DMHT]. 
conceded that Congress would not take up the TPP during his presidency. ${ }^{227}$ Immediately after taking office, President Trump announced he would "unsign" the TPP. ${ }^{228}$ Ironically, President Trump also announced he would use the trade promotion authority Congress conferred in 2015 to renegotiate NAFTA. ${ }^{229}$ The resulting agreement, which has been signed but has not entered into force as of the time of writing, largely eliminates ISDS except for a few narrow categories of cases; limits the agreement to a sixteen-year term, subject to review and renewal (most trade agreements are of indefinite duration); and makes two changes to the rules determining whether autos qualify for duty free treatment: (1) the amount of North American content necessary for a vehicle to be eligible was raised from 62.5 percent to 75 percent, and (2) a minimum percentage of the vehicle's content must be made by workers making at least $\$ 16$ an hour. ${ }^{230}$

$* * *$

As a result of the internationalization of trade policy and the shift toward FTAs, trade became increasingly unhooked from both the domestic economics and foreign policy justifications that undergird trade's role in our constitutional system. The result is not surprising. In the context of a shrinking middle class, increased economic anxiety, and rising wealth and income inequality, political support for trade agreements has become fragile at best. Without specific foreign policy or national security aims to justify such agreements, the case for liberalization becomes one that relies more on domestic economics. And yet the distributional effects of these agreements are hotly contested, and the process by which the agreements are concluded minimizes the role of domestic politics. By moving beyond the balance of trade powers outlined in the Constitution, trade policy and politics have created their own crisis.

II.

TRADE'S BOUNDARY PROBLEM

Trade is a classic "intermestic" issue, an area that bridges the international and domestic spheres. For example, the tariff that serves to encourage infant industries or raise revenue at home also restricts a foreign country seeking markets for its exports. Viewed from one side, the domestic economics paradigm applies; from the other, the foreign affairs paradigm. Technology,

227. Alan Yuhas, Congress Will Abandon Trans-Pacific Partnership, White House Concedes, THE GuARDIAN (Nov. 12, 2016), https://www.theguardian.com/business/2016/nov/12/tpp-trade-dealcongress-obama [https://perma.cc/U9PG-TKJN].

228. Eric Bradner, Trump to Begin Renegotiating NAFTA with Leaders of Mexico, Canada, CNN (Jan. 22, 2017), https://www.cnn.com/2017/01/22/politics/trump-renegotiate-nafta/index.html [https://perma.cc/CD5T-APS3].

229. Id.

230. Heather Long, New NAFTA: U.S., Canada and Mexico Just Reached a Sweeping New NAFTA Deal. Here's What's In It, WASH. POST: WONKBLOG (Oct. 1, 2018), https://www.washingtonpost.com/business/2018/10/01/us-canada-mexico-just-reached-sweepingnew-nafta-deal-heres-whats-it/?utm_term=.dc9305d667d6 [https://perma.cc/4D8S-5XMW]. 
communications, and transportation have deepened the two-faced view of tariffs. Professor Jack Goldsmith has observed, "[A]s the world becomes more interconnected, domestic law and activity increasingly have foreign consequences, and vice versa." 231 For example, corporations have increasingly established global supply chains for their goods, meaning that a single product might have components sourced from multiple countries, including the final country-of-sale. ${ }^{232}$ Global production and distribution chains implicate a variety of issues beyond tariffs: regulatory compliance, taxation, national security policy, and data privacy. They even call into question the old saw, "What's good for GM is good for America." If an American company has most of its operations abroad, wouldn't directors have an obligation to shareholders to act against American interests if it improves shareholder value ${ }^{233}$ This is trade's boundary problem: trade invariably is at once domestic and foreign.

Perhaps the best examples of trade's boundary problem are nontariff barriers (NTBs) to trade. NTBs, recall, are domestic laws or regulations that impede trade, including regulations on issues such as health, safety, and the environment. Such regulations can be challenged through the WTO, resulting in potential liability for WTO members. For instance, in 2009 Congress passed the Family Smoking Prevention and Tobacco Control Act. The statute aimed to reduce youth smoking by eliminating the primary gateway to smoking, flavored cigarettes. $^{234}$ The statute, however, carved out an exception for menthol cigarettes. ${ }^{235}$ Indonesia successfully challenged the statute at the WTO, arguing that the exception for menthol cigarettes (produced mostly in the United States) discriminated against clove cigarettes (produced mostly in Indonesia). ${ }^{236}$ Similarly, US efforts to implement measures, such as a dolphin-safe labeling scheme for tuna imported into the United States, have been successfully challenged before the WTO, leading the United States to change its requirements. ${ }^{237}$

Trade's boundary problem also gives the President the incentive to frame a wide swath of policies as foreign affairs, rather than domestic economics. When

231. Jack L. Goldsmith, Federal Courts, Foreign Affairs, and Federalism, 83 VA. L. REV. 1617, 1672 (1997).

232. For a discussion of global supply chains and new era of rising protectionism, see Justin Rose \& Martin Reeves, Rethinking Your Supply Chain in an Era of Protectionism, BCG HENDERSON INST. (Apr. 27, 2017), https://www.bcg.com/publications/2017/lean-manufacturing-rethinking-supply-chainera-protectionism.aspx [https://perma.cc/7WQ5-BR7M]; JOSEPH E. STIGLITZ, GLOBALIZATION AND ITS DISCONTENTS REVISITED: ANTI-GLOBALIZATION IN THE ERA OF TRUMP 378-79 (2017).

233. For a philosophical discussion this problem, see generally David G. Yosifon, Is Corporate Patriotism a Virtue?, 14 SANTA ClARA L. REV. 265 (2016).

234. See Appellate Body Report, United States-Measures Affecting the Production and Sale of Clove Cigarettes, WTO Doc. WT/DS406/AB (adopted Apr. 24, 2012).

235. Id.

236. Id.

237. Appellate Body Report, United States-Measures Concerning the Import, Marketing and Sale of Tuna and Tuna Products, WTO Doc. WT/DS381/AB (adopted June 13, 2012). 
viewed through the foreign affairs paradigm, the process for making law involves presidential leadership, severely restricted interest group involvement, limited public or congressional knowledge or pressure over the terms of the deal, and a fast-tracked ratifying vote by Congress. Compared to the traditional legislative process, the trade agreement approach is far less complex, uncertain, and costly (in terms of time and political capital) for the President. The result is that the dominance of the foreign affairs paradigm should lead not only to expansive presidential power but also to the President increasingly framing domestic policy in foreign affairs terms. ${ }^{238}$

Trade's boundary problem, of course, is not insurmountable. Boundary problems are pervasive in law. ${ }^{239}$ The answer is not to slide down the slippery slope and accept that anything framed broadly as "foreign affairs" is exempt from the traditional legislative process. ${ }^{240}$ Below, we argue that despite trade's boundary problem, Congress - and by extension domestic economic concernsshould play the preeminent role in contemporary American trade policy for three reasons. First, the concerns that animate arguments for foreign affairs exceptionalism in other contexts do not apply to trade policy. Second, the Founders gave control of trade policy to a "parochial" Congress beholden to local constituencies precisely so that local interests could influence trade policy. Third, the President's trade policy can be captured by interests just as parochial as those that capture Congress. Giving the President control of trade policy, as under the foreign affairs paradigm, neither ensures implementation of a policy that maximizes national welfare nor comports with the constitutional structure.

\section{A. Normalizing Trade Law}

Within the separation of powers, the foreign affairs paradigm places trade law and policy within the executive branch for a variety of functional reasons, including expertise, speed, and secrecy. As Alexander Hamilton wrote in Federalist 70, "[d]ecision, activity, secrecy, and dispatch will generally characterize the proceedings of one man in a much more eminent degree than the proceedings of any greater number; and in proportion as the number is increased, these qualities will be diminished." ${ }^{241}$ Some scholars have recently argued that

238. Cf. Ganesh Sitaraman \& Ingrid Wuerth, National Security Exceptionalism and the Travel Ban Litigation, LAWFARE (Oct. 12, 2017), https://www.lawfareblog.com/national-securityexceptionalism-and-travel-ban-litigation [https://perma.cc/8H2S-LD9S] (making the incentive-effects argument with respect to national security and immigration).

239. For applications in the foreign affairs context, see Derek Jinks \& Neal Kumar Katyal, Disregarding Foreign Relations Law, 116 YALE L.J. 1230, 1257 (2007); Sitaraman \& Wuerth, supra note 7 , at $1942-44$.

240. See generally Frederick Schauer, Slippery Slopes, 99 HARV. L. REV. 361 (1985) (explaining the components and prevalence of "slippery slope" arguments in legal contexts); Eugene Volokh, The Mechanisms of the Slippery Slope, 116 HARV. L. REV. 1026 (2003) (describing the general risks posed by a "slippery slope").

241. THE FEDERALIST No. 70, at 423 (Alexander Hamilton) (Clinton Rossiter ed., 2003); see also EDWARD S. CORWIN, THE PRESIDENT 201 (5th ed. 1984) (noting "the unity of the office [of the 
foreign affairs should not be treated differently from domestic affairs as a categorical matter, but rather that these functional justifications for expansive executive power should be evaluated on a subfield-by-subfield or even issue-byissue basis. ${ }^{242}$ The reason is that the particular functional justifications for deference might not apply in some fields but do in others. Taking this more careful approach to justifying deference, most of the conventional justifications for expansive deference to the executive are either inapplicable or relatively weak in the trade context.

\section{Expertise}

Start with expertise. It is likely true that the executive branch has more substantive expertise than Congress does with respect to technical information on international economic issues. Certainly, the executive branch has more institutional capacity in terms of personnel and resources. ${ }^{243}$ But it is not clear why greater expertise or institutional capacity implies that there should be greater executive power over trade matters. As one of us has argued, "it is equally true that [members of the executive branch] know more about food and drug policy, environmental policy, banking regulation, and Medicare reimbursements" than members of Congress. ${ }^{244}$ And yet those "domestic" areas are well understood to be squarely within the purview of the legislative process.

Additionally, while all foreign affairs issues have some domestic impact and vice versa, trade is more obviously intertwined with domestic economic policy than many other foreign affairs issues. Whether the issue is tariffs that encourage infant industry, revenue-raising measures, national security imperatives, or "non-tariff" regulatory barriers, the bread and butter of trade agreements are fundamentally different from, say, peace treaties or military alliances. The latter largely require judgments about the place of the United States and foreign nations in the larger geopolitical context. The former implicates jobs, wages, economic competition domestically, and a variety of other constituent interests. These are precisely the kinds of factors in which Congress is considered to have superior institutional competence because of its representative nature. In the Federalist Papers, James Madison argued that members of the House of Representatives would bring critical knowledge of their

President], its capacity for secrecy and dispatch, and its superior sources of information; to which should be added the fact that it is always on hand and ready for action, whereas the houses of Congress are in adjournment much of the time"); HAROLD HONGJU KOH, THE NATIONAL SECURITY CONSTITUTION 119 (1990) (noting that the President's "decision-making processes can take on degrees of speed, secrecy, flexibility, and efficiency that no other governmental institution can match").

242. Sitaraman \& Wuerth, supra note 7, at 1935-49.

243. See United States v. Curtiss-Wright Exp. Corp., 299 U.S. 304, 320 (1936); Robert Knowles, American Hegemony and the Foreign Affairs Constitution, 41 ARIZ. ST. L.J. 87, 128 (2009). Note that the executive's comparative expertise is itself a function of a congressional decision to allocate resources to the executive branch such that it has that expertise.

244. Sitaraman \& Wuerth, supra note 7, at 1936. 
constituents' circumstances to federal policy-making and that biennial elections would keep members of Congress tethered to the interests of their constituents. ${ }^{245}$ He even thought they would be particularly well-suited to address trade policy: "How can foreign trade be properly regulated by uniform laws," he asked in Federalist 53, "without some acquaintance with the commerce, the ports, the usages, and the regulations of the different state[s]?"246 The House of Representatives brings that granular knowledge of the diverse circumstances of a large nation to the policy-making process.

\section{2. $\quad$ Speed}

Now consider speed, or "dispatch" as Hamilton put it. While a variety of scholars have argued that speed is a "general characteristic of foreign relations," ${ }^{477}$ it is not clear why speed is necessary in the realm of international trade. Trade agreements often take years to conclude, and they move in fits and starts as political and economic conditions change around the world. For example, the Uruguay Round of GATT negotiations began in 1986 and only concluded in 1994 with the signing of the Marrakesh agreement. ${ }^{248}$ That a trade agreement can be characterized as "foreign" hardly implies that speed is essential. In contrast, in some cases, such as financial crises and natural disasters, purely domestic emergencies might require more timely action. As a result, the foreign/domestic distinction is poorly tailored to the functional need for "dispatch." A far better distinction would be emergency/non-emergency or crisis/non-crisis. ${ }^{249}$

\section{Secrecy}

Finally, secrecy. ${ }^{250}$ During the Constitutional Convention, there was a debate on whether the Senate alone or the Senate and the House of

245. FedERAlist No. 53 (James Madison), at 301 (Clinton Rossiter ed., 2003); see also FEDERALIST No. 56 (James Madison), at 301 (Clinton Rossiter ed., 2003) (explaining why the House of Representatives will effectively represent diverse interests).

246. FEDERALIST No. 53 (James Madison), at 301 (Clinton Rossiter ed., 2003).

247. See, e.g., Eric A. Posner \& Cass R. Sunstein, Chevronizing Foreign Relations Law, 116 YALE L.J. 1170, 1217 (2007) (making this point with reference to the appropriate role of the judiciary in foreign affairs cases). For commentary aligning executive power, speed, and foreign affairs, see Corwin, supra note 241, at 202; Koh, supra note 241, at 119; John C. Yoo, War and the Constitutional Text, 69 U. CHI. L. REV. 1639, 1676 (2002) (“'A] unitary executive can evaluate threats, consider policy choices, and mobilize national resources with a speed and energy that is far superior to any other branch.").

248. I.M. Destler, AMERICAN TRAde POLITICS 54, 219 (4th ed. 2005).

249. Sitaraman \& Wuerth, supra note 7, at 1939; Eric A. Posner \& Adrian Vermeule, Crisis Governance in the Administrative State: $9 / 11$ and the Financial Meltdown of 2008, 76 U. CHI. L. REV. 1613, 1636-39 (2009) (discussing executive action in the wake of the September 11 terrorist attacks and 2008 financial crisis).

250. By this we don't mean secret treaties, but secrecy in the process of making a treaty. On secret treaties, see generally Megan Donaldson, The Survival of the Secret Treaty: Publicity, Secrecy, and Legality in the International Order, 111 AM. J. INT'L L. 575 (2017). 
Representatives together would have a role in advising on treaty negotiations. James Wilson argued that the need for secrecy in treaty negotiations was "outweighed" by the benefits of "obtaining the Legislative sanction." ${ }^{251}$ Roger Sherman responded that the "necessity of secrecy in the case of treaties forbade a reference of them to the whole Legislature." Sherman's view, relying on the importance of the small number of Senators (twenty-six at the time), carried the day. ${ }^{252}$ John Jay made a similar argument in Federalist 64. "[I]n the negotiation of treaties," he noted, "perfect secrecy and immediate dispatch are sometimes requisite." 253

The Federal Farmer, however, made the more interesting argument, noting during the ratification debates that "commercial treaties" were different from "treaties of peace and alliance" because the "latter generally require secrecy, [and] it is but very seldom they interfere with the laws and internal police of the country." In contrast, commercial treaties "do not generally require secrecy, they almost always involve in them legislative powers, interfere with the laws and internal police of the country, and operate immediately on persons and property, especially in the commercial towns... they consist of rules and regulations." These were, he argued, the province of Congress under its Article I commerce powers. ${ }^{254}$ While Sherman and Jay took a foreign affairs perspective across the board, the Federal Farmer recognized the distinctive nature of trade agreements.

In contemporary practice, the executive branch keeps draft language from trade agreements classified up until the entire agreement is finalized. ${ }^{255}$ This means that large sections of the text might be finalized among the parties and yet unavailable to the general public until the entirety of the agreement is concluded.

Functionally, this practice makes little sense. First, as Federal Farmer and some modern commentators have argued, trade agreements that make regulatory changes to domestic economic policy issues have no inherent need for secrecy and might in fact benefit from transparency and the attendant public participation and feedback. ${ }^{256}$ Second, the justification for the secrecy of drafts (rather than the negotiating positions themselves) is extremely weak. By definition the negotiating parties on the other side of the agreement are aware of the draft agreement, so there is no secrecy interest in the draft (and particularly in the

251. 2 THE RECORDS OF THE FEDERAL CONVENTION OF 1787, at 538 (Max Farrand ed., 1937).

252. Id.

253. FEDERALIST No. 64 (John Jay), at 390 (Clinton Rossiter ed., 2003).

254. Letter XI from Federal Farmer (Jan. 10, 1788), in 17 DOCUMENTARY HiSTORY OF THE RATIFICATION OF THE CONSTITUTION 308-10.

255. Adkins \& Grewal, supra note 9, at 1511-12.

256. On the modern side, see John C. Yoo, Treaties and Public Lawmaking: A Textual and Structural Defense of Non-Self- Execution, 99 ColuM. L. REv. 2218, 2241 n.85 (1999) ("Even if the Senate is better disposed to diplomacy than the House, multilateral treaties that impose domestic rules of conduct do not demand secrecy or speed of action. Only those treaties that have the least domestic effect, and hence need no implementing legislation, such as military or political alliances, demand secrecy."). 
completed sections of a draft) with respect to the foreign country. ${ }^{257}$ Third, while it is true that public disclosure of negotiating practices might chill negotiators' ability to speak freely in the negotiations, commentators calling for greater transparency in trade agreements have not asked to see negotiators' notes or strategies or even to have the negotiations themselves take place in public view. Rather, they argue for giving the public access to drafts that are shared with all the parties and with industry advisory groups. ${ }^{258}$ Indeed, negotiating partners, including the EU, routinely release their side of trade agreements. ${ }^{259}$

In sum, the oft-recited functional arguments for expansive foreign affairs deference to the President - expertise, speed, and secrecy-are all either inapplicable or significantly weaker in the trade context than in other domains within foreign relations. Clumping trade with other foreign relations issues and treating them as exceptional under the separation of powers (and therefore suited to expansive presidential power) thus makes little sense. A far better approach would be to "normalize" trade and see it as governed by ordinary separation-ofpowers principles, in which Congress has valuable functional contributions to make to policy-making, not to mention significant Article I authorities.

\section{B. The Benefits of a Parochial Congress}

A common trope in separation-of-powers scholarship is that the President represents a national constituency, while the Congress represents local interests. ${ }^{260}$ In trade law, commentators and lawmakers invoke this argument to justify the delegation of congressional power to the President. ${ }^{261}$ The theory is

257. See Senator Elizabeth Warren, Speech in the United States Senate (May 21, 2015) $\begin{array}{lll}\text { [hereinafter Elizabeth } & \text { Warren }\end{array}$ https://www.realclearpolitics.com/video/2015/05/21/warren_trade_deal_secret_because_if_details_we re_made_public_now_the_public_would_oppose_it.html [https://perma.cc/J9LY-YHTG].

258. See, e.g., Trade Transparency Act of 2015, S. 1381, 114th Congress (2015); Press Release, Joe Manchin, Senators Manchin and Warren Introduce 'Trade Transparency Act' (May 19, 2015), https://www.manchin.senate.gov/newsroom/press-releases/senators-manchin-and-warren-introducetrade-transparency-act [https://perma.cc/8UMH-YAAC].

259. Margot E. Kaminski, Don't Keep the Trans-Pacific Partnership Talks Secret, N.Y. TIMES (Apr. 14, 2015), https://www.nytimes.com/2015/04/14/opinion/dont-keep-trade-talks-secret.html [https://perma.cc/7Z7P-CK5J].

260. See, e.g., Jide Nzelibe, The Fable of the Nationalist President and the Parochial Congress, U.C.L.A. L. REV. 1217 (2006) (criticizing the view that the president will pursue policies that advance the aggregate good, while members of Congress will pursue policies that only advance the local good); Steven G. Calabresi, Some Normative Arguments for the Unitary Executive, 48 ARK. L. REv. 23, 35 (1995); Elena Kagan, Presidential Administration, 114 HARV. L. REV. 2245, 2335 (2001) (“[B]ecause the President has a national constituency, he is likely to consider, in setting the direction of administrative policy on an ongoing basis, the preferences of the general public, rather than merely parochial interests."); Lawrence Lessig \& Cass R. Sunstein, The President and the Administration, 94 COLuM. L. REV. 1, 105-06 (1994) (“[B]ecause the President has a national constituency—unlike relevant members of Congress, who oversee independent agencies with often parochial agendas - it appears to operate as an important counterweight to factional influence over administration.").

261. See, e.g., DEVEREAUX, LAWRENCE \& WATKINS, supra note 16, at 188 ("The president, whose constituency is the entire nation, is likely in the best position . . . to represent the overall national interest in open trade."). 
that by empowering the national President, the parochial Congress ensures that the institution best able to act in the national interest is the institution setting American trade policy. Not coincidentally, under this theory the national interest is synonymous with trade liberalization. Reducing barriers to trade increases national wealth in the aggregate, which is - regardless of the distribution of that wealth - deemed in the national interest. Once one defines that national interest in this way, it follows straightforwardly that the executive is best able to act in the "national" interest. The President, after all, has historically favored trade liberalization, while Congress tends to be more protectionist.

In political economy terms, this argument boils down to a claim that government should pursue economic efficiency-and not concern itself with distributional considerations - in its choice of trade policy. ${ }^{262}$ The goal of the separation of powers is not, however, to produce particular policy outcomes, such as trade liberalization. Nor, as the Supreme Court has repeatedly admonished, is political efficiency a value that the Framers of our Constitution prized especially highly when they designed our system of government. ${ }^{263}$ As Justice Brandeis put it,

The doctrine of the separation of powers was adopted by the Convention of 1787 not to promote efficiency but to preclude the exercise of arbitrary power. The purpose was not to avoid friction, but, by means of the inevitable friction incident to the distribution of the governmental powers among three departments, to save the people from autocracy. ${ }^{264}$

Put less starkly, the Constitution gives Congress the primary role in establishing national laws precisely to ensure "a step-by-step, deliberate and deliberative process" that will often be "clumsy, inefficient, even unworkable."265

Local and "parochial" interests are, by constitutional design, at the core of this deliberative process. ${ }^{266}$ Members of Congress have a wide range of

262. Commentators often argue that distributional issues arising from trade policy should not be ignored, but rather should be resolved through domestic policy. See, e.g., Dan Ikenson, Crucifying Trade for the Sins of Domestic Policy, FORBES (March 28, 2016), https://www.forbes.com/sites/danikenson/2016/03/28/crucifying-trade-for-the-sins-of-domesticpolicy/\#6f72807b70eb [https://perma.cc/DN4Q-PVAC]. The problem with this claim is that trade's distributional issues are not, in fact, addressed outside of trade. As a consequence, voters are increasingly demanding that trade policy itself directly address these distributional issues. See Meyer, supra note 206, at 988 .

263. INS v. Chadha, 462 U.S. 919, 959 (1983) ("[T]he Framers ranked other values higher than efficiency."); Youngstown Sheet \& Tube Co. v. Sawyer, 343 U.S. 579, 629-30 (1952) (Douglas, J., concurring) ("All executive power ... has the outward appearance of efficiency. [But we] cannot decide this case by determining which branch of government can deal most expeditiously with the present crisis. The answer must depend on the allocation of powers under the Constitution.").

264. Myers v. United States, 272 U.S. 52, 85 (1926) (Brandeis, J., dissenting).

265. Chadha, 462 U.S. at 959.

266. Cf. Garcia v. San Antonio Met. Trans. Auth., 469 U.S. 528, 556 (1985) (holding that state and local interests are protected through local and state election of the members of Congress); Herbert Wechsler, The Political Safeguards of Federalism: The Role of the States in the Composition and Selection of the National Government, 54 CoLUM. L. REV. 543, 544-45 (1954) (outlining the historic and ongoing centrality of states' interests within a federalist system). 
constituencies. By virtue of local or state election, they are beholden to interests located in their districts or states. By setting elections up this way-and by later providing for direct election of senators - the Framers intended that Congress be the main avenue through which local interests would exert influence over law and policy. ${ }^{267}$ Similarly, other interests-such as farmers, labor unions, environmentalists, and small businesses - have an easier time finding a voice in the political process through Congress. ${ }^{268}$ Such interests may have difficulty attracting the attention of the President or unelected administrative agencies, but 535 members of Congress provide many more opportunities for interaction. These entry points into the lawmaking process are a feature, not a bug. They ensure that trade policy, or any policy for that matter, reflects the diverse set of interests that exist in our nation. In the economic language that often dominates discussions of trade policy, our constitutional system mandates that trade policy be made in light of distributional considerations, not efficiency considerations.

Recent legislation introduced by Michigan Senator Gary Peters and North Carolina Senator Richard Burr illustrates the point. The two senators introduced a bill that would create a task force within the Commerce Department charged with initiating trade remedies investigations affecting small and medium-sized businesses. ${ }^{269}$ Under existing law, American producers can petition the government to impose extra duties on goods that are either dumped at unfair prices into the United States or benefit from illegal subsidies. Doing so, however, requires hiring expensive law firms, and although the Commerce Department has authority to self-initiate investigations, it rarely does so. ${ }^{270}$ Unable to access trade remedies through the Commerce Department due to legal costs and difficulties with getting a remote agency in D.C. to take action, these businesses have turned to Congress for aid. Congress, in other words, provides an avenue of relief for individuals and institutions that cannot influence government policy through other channels.

The chief problem with the foreign affairs paradigm is that it systematically disadvantages the plurality of interests that is core to American democracy and which the Framers intended Congress to represent. The process by which trade agreements are negotiated is far less transparent and participatory than the legislative process because the executive branch is a gatekeeper for determining

267. See Garcia, 469 U.S. at 550-51 ("[T]he principal means chosen by the Framers to ensure the role of the States in the federal system lies in the structure of the Federal Government itself.").

268. See Garcia, 469 U.S. at 565 \& n.9 (Powell, J., dissenting).

269. Vicki Needham, Senators Introduce Bill to Help Businesses with Trade Complaints, HILL (Feb. 15, 2018), https://thehill.com/policy/finance/374066-bipartisan-pair-of-senators-introduce-bill-tohelp-smaller-businesses-with [https://perma.cc/XS39-9TLN].

270. See Timothy Meyer, Free Trade, Fair Trade, and Selective Enforcement, 118 CoLuM. L. REV. 491, 505 (2018) (describing trade remedies measures such as antidumping and countervailing duties); Jennifer McCadney, In Rare Move, Trump's Commerce Secretary Self-Initiates Chinese Aluminum Trade Remedy Cases, TRADE \& MANU. MONITOR (Nov. 30, 2017), https://www.ustrademonitor.com/2017/11/in-rare-move-trumps-commerce-secretary-self-initiateschinese-aluminum-trade-remedy-cases [https://perma.cc/9P7D-YFM5]. 
which interest groups get access to government during negotiations. While the 1974 Act created industry advisory committees that could participate in trade negotiations, ${ }^{271}$ the advisory committee model is not a substitute for the legislative process, even in an era of "unorthodox lawmaking." 272 The advisory committees represent a limited number of interests and are heavily stacked in favor of industry. Of the 566 members of the TPP's twenty-eight advisory committees, 85 percent ( 480 members) were industry lobbyists or corporate executives. ${ }^{273}$ Some committees were entirely made up of industry representatives. The US Trade Representative also uses national security classification to restrict the availability of negotiation drafts only to the members of the committee and members of Congress. ${ }^{274}$ This restricts congressional involvement and oversight because members of Congress are prohibited from talking about the agreement in public or reading their staffs into the agreement. ${ }^{275}$ It also prevents the general public from bringing pressure to bear on the terms of the agreement. Unless an interested party is afforded the privilege of entry into one of the industry advisory committees, it has limited power to shape the agreement's terms.

Executive-dominated trade lawmaking also effectively allows the President to increase the costs to Congress of passing domestic laws that address the distributional issues raised by, or that run afoul of, trade agreements. This consideration is most prominent in what we might term the "two-step" problem. As noted above, in the post-Cold War era, economists and commentators who support trade liberalization as an economic policy have done so on the grounds that it expands aggregate welfare. ${ }^{276}$ Such commentators urge policy-makers to use domestic lawmaking to address trade's distributional problem, rather than trade policy. ${ }^{277}$ But separating trade liberalization from distributional issues limits the ability of members of Congress to use trade liberalization as leverage in negotiations to redistribute the gains from trade. ${ }^{278}$ The constrained consideration that trade agreements receive in Congress under fast-track only

271. Trade Act of $1974 \S 135,19$ U.S.C. $\$ 2155$ (2018)

272. See generally BARBARA SinCLAIR, UNORTHODOX LAWMAKING: NEW LEGISLATIVE PROCESSES IN THE U.S. CONGRESS (4th ed. 2011) (describing new and changed legislative processes in the U.S. Congress in the early and mid-2000s).

273. Elizabeth Warren \& Rosa DeLauro, Who is Writing the TPP?, Bos. GLOBE (May 11, 2015), https://www.bostonglobe.com/opinion/2015/05/11/elizabeth-warren-and-rosa-delauro-who-writingtpp/2FQZAV6uz9GGQI6pe3cd0K/story.html [https://perma.cc/45KH-LF3A]

274. Adkins \& Grewal, supra note 9, at 1511-12.

275. Elizabeth Warren Speech, supra note 257.

276. See supra Part I.C.

277. See, e.g., Ikenson, supra note 262; PAUl R. KRUGMAN \& MAURICE ObSTFELD, INTERNATIONAL ECONOMICS: THEORY AND POLICY 216 (7th ed. 2005) (“Any proposed trade policy should always be compared with a purely domestic policy aimed at correcting the same problem. If the domestic policy appears too costly or has undesirable side effects, the trade policy is almost surely even less desirable").

278. See generally Timothy Meyer, Misaligned Lawmaking (unpublished manuscript) (on file with authors). 
further undermines the ability to link these two policies. In effect, members of Congress get an up-or-down vote on trade agreements, which limits their ability to link passage of the agreement to legislation aimed at redistributing the gains from trade. If members of Congress try to bring up the distributional issues later, trade liberalization's advocates have little reason to negotiate, since they already have their trade agreement. ${ }^{279}$

Entrenching regulatory policies through trade agreements can also raise the cost of future legislative change because violating trade agreements has consequences. Countries that violate an agreement can be subject to retaliatory trade restrictions unless they either remove the measure or reach a settlement. ${ }^{280}$ Of course, a later-in-time statute trumps an earlier-in-time statute, and a past Congress cannot bind a future Congress. ${ }^{281}$ This rule, which applies equally to trade legislation, enables Congress to shift policies in light of changed circumstances, including changes in public preferences. And to be sure, Congress often seems oblivious to trade rules, regularly passing legislation that raises WTO problems. ${ }^{282}$ But at least in principle, trade agreements create costs that constrain future Congresses.

Entrenchment is not a problem, per se. Most congressional acts are difficult to change, in part because of the potential economic and political costs of doing so, and are thus entrenched to some degree. Moreover, international law is supposed to work in this fashion. It allows countries to make credible commitments to cooperative policies precisely because it does create future costs to changing those policies. ${ }^{283}$

The problem in the trade context, specifically, is that Congress does not go through its ordinary legislative process in passing legislation implementing the trade agreements that create the initial entrenchment. ${ }^{284}$ During the initial negotiations over trade obligations, when the United States is unburdened by international obligations, the President dominates lawmaking. Only afterwards, when international commitments create an incentive not to change domestic policy, does Congress have the unfettered ability to propose, debate, and amend legislation. The result is that smaller constituencies and groups that rely on

279. Id.

280. DSU, supra note 160, art. 22 (describing the procedures for suspending trade concessions in retaliation for breaching trade commitments).

281. Cf. Whitney v. Robinson, 124 U.S. 190 (1888) (discussing the same relationship between treaties and statutes under the supremacy clause).

282. See, e.g., Anne-Sylvaine Chassany, EU Finance Ministers Warn U.S. Administration Over Tax Bill, FIN. TIMES (Dec. 11, 2017), https://www.ft.com/content/96f4dbda-ac34-3ef6-8627f064563df310 [https://perma.cc/D4E9-62C4] (reporting the EU finance minister's view that the 2017 U.S. tax reform "contravenes" WTO rules).

283. See generally ANDREW T. GUZMAN, HOW INTERNATIONAL LAW WORKS: A RATIONAL CHOICE THEORY (2008) (laying out a theory of how international law creates costs for violations).

284. Even the Art. II treaty making process, which requires a supermajority of the Senate to consent to an international agreement, would involve more deliberation than the fast-track procedures used for trade agreements. 
Congress to advance their interests are disadvantaged. They cannot provide meaningful input into the initial formulation of trade law because they cannot influence the executive branch, and Congress only gets an up-or-down vote on the measure. Later, when Congress can consider legislation unfettered, it also has to consider the negative consequences of breaching trade agreementssomething it would not have had to consider at the initial negotiation stage.

In addition, the process of presidential negotiation and a take-it-or-leave-it fast-track approval regime means that the President has agenda-setting power domestically, which allows him to resolve conflicts among competing constituencies in Congress. If, for example, we imagine that Congress suffers from problems of cycling in policy preferences, as the Arrow Theorem suggests, then the President effectively ends up as the decider. By shifting the resolution of competing preferences outside of Congress, presidential agenda-setting disadvantages interests in Congress that are not necessarily aligned with the executive branch. This shift might be appealing from a political efficiency point of view, but it nonetheless undermines Congress's representative function.

Moreover, Congress does appear responsive to the possibility of trade liability when considering legislation, at least in some circumstances. In 2017, House Speaker Paul Ryan and Ways and Means Committee Chairman Kevin Brady proposed a "border adjustment tax."285 The proposal would have addressed a long-running concern that the US tax system disadvantages US companies vis-à-vis most other countries that have a value-added tax (VAT). ${ }^{286}$ VATs are refunded at the border on exports and are, by agreement, permitted under WTO rules. ${ }^{287}$ Since the United States does not have a VAT, US companies do not receive a similar refund when they export goods, but they do have to pay VAT in other countries. The Ryan-Brady plan would have moved the United States very close to a VAT system, but the kinds of deductions the plan allowed US exporters to claim raised WTO concerns. ${ }^{288}$ These concerns were high-profile and contributed to the decision not to go forward with the border-adjustment tax.

285. Veronique de Rugy, Phasing in the Border-Adjustment Tax Won't Solve Its Problems, NAT. REV. (June 15, 2017), https://www.nationalreview.com/corner/border-adjustment-tax-tax-reform-paulryan-kevin-brady-still-committed [https://perma.cc/3284-JXS3].

286. See Press Release, House Ways and Means Comm., Ending the 'Made in America' Tax: Three Major Wins for the American People (Dec. 21, 2016), https://waysandmeans.house.gov/endingmade-america-tax-three-major-wins-american-people [https://perma.cc/9ZPD-UQWX].

287. See Agreement on Subsidies and Countervailing Measures, Annex I (g)-(h) \& nn. 58-60, Apr. 15, 1994, Marrakesh Agreement Establishing the World Trade Organization, Annex 1A, 1869 U.N.T.S. 14 [hereinafter Agreement on Subsidies and Countervailing Measures] (providing that valueadded taxes may be refunded on export so long as the remitted taxes do not exceed the taxes levied on products destined for domestic consumption).

288. Shawn Donnan, Barney Jopson, \& Paul McLean, EU and Others Gear Up for WTO Challenge to US Border Tax, FIN. TIMES (Feb. 13, 2017), https://www.ft.com/content/cdaa0b76-f20d11e6-8758-6876151821a6 [https://perma.cc/PPZ8-M69Y]. 


\section{The Captured Trade Presidency}

Finally, the notion that the President formulates trade policy pursuant to the general national interest defies everything we know about politics. Proponents of the view that the President represents the national interest generally cite the fact that the President is nationally elected. ${ }^{289}$ The President does not, however, need to win the votes of the entire nation - or even a majority of voters - to be elected. As in many elections, presidents must assemble a coalition of 51 percent to be elected. In the case of presidents, this means 51 percent of electoral college voters, not of all voters, meaning that presidents, such as President George W. Bush and President Trump, can be elected with a minority of the popular vote. Much research in political science suggests that elected officials cater policy to their winning coalitions. ${ }^{290}$ Indeed, they have an incentive not to expand their coalition because attracting support beyond the minimum necessary to win an election is costly. ${ }^{291}$ Given these realities, the mere fact that presidents are elected nationally tells us little about whether they will actually pursue a trade policy in the national interest.

Presidential administrations are also subject to capture in the same way that congressional leaders are. Lobbyists work hard to influence administrations' positions on trade negotiations. Indeed, through the US Trade Representative's Advisory Committees, interest groups, especially industry, are given a seat at the table. What makes lobbying of presidential administrations different from lobbying members of Congress, though, is that there is only one president. The singular president means that influencing the administration's position is more difficult and expensive, precisely because many more groups are vying for presidential attention. If a decision is made in Congress, interest groups can seek influence through any of the 535 members. ${ }^{292}$ If decisions are made in the executive branch, the channels for influence are narrower.

The allocation of authority over trade policy within the executive branch compounds the effect of a narrow channel of influence. The executive branch is, of course, a "they" and not an "it." ${ }^{293}$ Hence, it is possible to lobby different

289. See, e.g., DEVEREAUX, LAWRENCE \& WATKINS, supra note 16, at 188.

290. See generally, WILLIAM H. RIKER, THE THEORY OF POLITICAL COALITIONS (1962); JAMES M. BuChANAN \& GORDON TUlLOCK, THE CALCUlus OF CONSENT (1962); see also Robert Aumann \& Mordecai Kurz, Power and Taxes, 45 ECONOMETRICA 1137 (1977) (describing how officials' constituencies and winning coalitions shape tax policies).

291. RIKER, supra note 290; but see Barry R. Weingast, A Rational Choice Perspective on Congressional Norms, 23 AM. J. POL. SCI. 245, 245 (1979) (critiquing the prediction that "majorities will be of the barest possible size, since [a minimum winning coalition] maximizes the per capita gains for the winners."). Weingast goes on to note that, as applied to legislative negotiations, the prediction of a minimum winning coalition has limited empirical support, although there is reason to believe this could change in the modern era of hyper-polarization. $I d$.

292. We do not mean to suggest that Congress does not have power structures that make some members more powerful than others.

293. Lisa Schultz Bressman \& Michael P. Vandenbergh, Inside the Administrative State: A Critical Look at the Practice of Presidential Control, 105 MicH. L. REV. 47, 49 (2006) ("[W]e 
agencies that work on the same issue. However, the dominance of the US Trade Representative in trade negotiations even limits these other avenues of influence. When the State Department ran trade negotiations, up until the 1960s, foreign policy experts and groups with connections to the Department played a dominant role in formulating trade policy. If the Commerce Department led trade negotiations, the domestic economic considerations that are that Department's bread-and-butter might play a more outsized role. But a separate US Trade Representative, which is housed in the Executive Office of the President cuts down on - although by no means eliminates - these other avenues of influence. Thus, even though the executive branch is a "they," for all intents and purposes, trade policy can be won at the White House.

Recent trade negotiations bear out the prediction that the executive branch is subject to capture and that the nature of the groups able to capture the administration's positions are narrow. Consider the TPP. President Obama touted the TPP as part of a “"[p]ivot' to Asia." ${ }^{294}$ Most of the provisions in TPP, however, were lifted from earlier US trade agreements. ${ }^{295}$ There was, in other words, nothing distinctly Asian about most of the TPP. Labor and environment groups had some success in pushing for stronger provisions. ${ }^{296}$ But although the TPP's labor and environment provisions were the most stringent ever included in a trade agreement, most labor and environmental groups remained cynical that they would have any effect. ${ }^{297}$

The Obama administration's negotiating position, however, was thoroughly captured by industry groups. At the level of process, the administration allowed industry groups privileged access to negotiating drafts that were otherwise kept secret, including from other interest groups and the public. Hence, representatives from the businesses that would benefit from the TPP had a hand in negotiations, while, for instance, labor groups whose

demonstrate that scholars may have underestimated the complexity of White House involvement. Presidential control is a 'they,' not an 'it.'").

294. Mike Green, The Legacy of Obama's "Pivot" to Asia, ForeIGN POL'Y (Sept. 3, 2016), https://foreignpolicy.com/2016/09/03/the-legacy-of-obamas-pivot-to-asia [https://perma.cc/W5CB$7 \mathrm{QPN}]$ (listing TPP as among the policy initiatives associated with Obama's Asia policy).

295. Todd Allee \& Andrew Lang, Who Wrote the Rules for the Trans-Pacific Partnership?, RES. \& POL. 1, 1 (July-Sept. 2016); see also Kathleen Claussen, Separation of Trade Law Powers, 43 YALE J. INT'L L. 315 \& n.4 (2018) (discussing studies showing "copy-paste" across agreements).

296. See Meyer, supra note 206, at 1005 (describing the labor and environment chapters of the TPP and the novel "consistency plans" that aimed to raise standards in countries like Vietnam).

297. See, e.g., Jackie Calmes, As Pacific Trade Negotiators Haggle, U.S. Officials Remain Hopeful, N.Y. TIMES (Oct. 4, 2015), https://www.nytimes.com/2015/10/05/business/us-and-11-nationsclose-to-accord-on-trade-pact.html [https://perma.cc/CKT4-RWMG] (noting that Obama Administration officials said the labor and environmental provisions were the "strongest ever"); $Q \& A$ : The Trans-Pacific Partnership, HuM. RTS. WATCH (Jan. 12, 2016), https://www.hrw.org/news/2016/01/12/qa-trans-pacific-partnership [https://perma.cc/MQ2D-SQRB] ("Human Rights Watch and others have expressed concerns that the agreement's labor chapter and associated bilateral agreements will not adequately safeguard labor rights in TPP countries with poor labor rights records, notably Vietnam, Malaysia, and Brunei."). 
constituents stood to be adversely impacted by the negotiations, were held at arms-length.

Not shockingly, this privileged access translated into privileged outcomes. The TPP broke new ground by creating rules on digital trade and e-commerce and data protections for pharmaceutical companies. The TPP also preserved investor-state dispute settlement, a procedure that US companies strongly favored, over the objection of groups within the United States and other TPP members, such as Australia. ${ }^{298}$ To be sure, these companies did not get everything they wanted. Pharmaceutical companies, for instance, wanted a longer data exclusivity period during which generic manufacturers of drugs could not piggyback on existing clinical trials to prove a generic drug's safety. ${ }^{299}$ But the real innovations in the TPP came in the form of the Obama administration's willingness to allow corporate groups access to negotiations and draft texts that even some members of Congress and their staffs had difficulty accessing. ${ }^{300}$

Given the ability of major economic players to capture the President's position on trade, the President can hardly be said to represent the national interest. Rather, like all elected officials, the President represents his supporters and those to whom he chooses to listen. Ironically, President Trump's election has driven this home for commentators who have long championed the "national" president in trade policy as a vehicle for championing aggressive trade

\footnotetext{
298. See Jurgen Kurtz, The Australian Trade Policy Statement on Investor-State Dispute $\begin{array}{llllll}\text { Settlement, } & 15 & \text { ASIL } & \text { InSIGHTS } & \text { (Aug. }\end{array}$ https://www.asil.org/insights/volume/15/issue/22/australian-trade-policy-statement-investor-statedispute-settlement [https://perma.cc/9YRH-ACDH] (discussing Australia's "opposition to investorstate dispute settlement provisions in future Australian trade agreements"); TPP, supra note 171, arts. 9.19-9.30.
}

299. Alex Philippidis, Biopharma Industry Blasts TPP Exclusivity Compromise, GEN: GENETIC ENGINEERING \& BIOTECH. NEWS (Oct. 6, 2015), https://www.genengnews.com/gen-newshighlights/biopharma-industry-blasts-tpp-exclusivity-compromise/81251827 [https://perma.cc/78VBBRWU] (quoting John Castellani, President and CEO of the Pharmaceutical Research and Manufacturers of America, as saying "[w]e are disappointed that the Ministers failed to secure 12 years of data protection for biologic medicines ... This term was not a random number, but the result of a long debate in Congress, which determined that this period of time captured the appropriate balance that stimulated research but gave access to biosimilars in a timely manner.").

300. See George Zornick, Congress is Sick of the Secrecy Around the TPP, NATION (Aug. 20, 2015) https://www.thenation.com/article/congress-is-sick-of-the-secrecy-around-tpp [https://perma.cc/ZTS8-8VCS] (noting that "close to 600 corporate executive and lobbyists enjoy wideranging access and input to the draft text"); Press Release, Sherrod Brown, Senator for Ohio, Brown to President Obama: Access to Text of Trans-Pacific Partnership Agreement Must Come Before Intent to Sign (Oct. 9, 2015), https://www.brown.senate.gov/newsroom/press/release/brown-to-presidentobama-access-to-text-of-trans-pacific-partnership-agreement-must-come-before-intent-to-sign [https://perma.cc/L3DA-CYJ2] ("Access to the text has been inadequate throughout the TPP negotiations. A copy of the agreement was not readily available for Members of Congress until we demanded it. And even after the text was deposited in the secure reading rooms in the House and Senate, Members had to ask USTR for TPP annexes and other related documents to be made available. In addition, despite repeated requests, congressional staff with the necessary security clearance are still prohibited from seeing the text on their own.”). 
liberalization. In response to his supporters, which include blue collar workers in states like Michigan and Ohio as well as companies struggling to compete with cheap imports, President Trump has acted aggressively to raise trade barriers. He "unsigned" the TPP; ${ }^{301}$ renegotiated NAFTA (an endeavor popular with his political base but unpopular in the business community); ${ }^{302}$ imposed tariffs on solar imports that seem likely to benefit a few companies at the expense of the broader US solar industry; ${ }^{303}$ and adopted trade restrictions on steel and aluminum imports. ${ }^{304}$

None of this should be surprising. The President is an elected official, subject to similar pressures as other elected officials. But it should caution against paradigms of trade policy-making that pretend the President is not subject to these pressures. In shifting power to the President, the foreign affairs paradigm has ultimately empowered those special interests with access to the President. They can use trade policy to set domestic economic policy that is neither necessarily in the national interest nor a product of the institution - Congressresponsible for such policy.

III.

\section{IMPLICATIONS AND EXTENSIONS}

In this Part, we explore the implications of approaching trade from a balanced perspective within the separation of powers. This "normalized" approach to trade law and policy has a variety of consequences for contemporary legal and policy debates. First, we argue that the role of fast track, or trade promotion authority, has been misunderstood in the legal literature, and suggest that the delegation of power to the executive under this authority may be indirectly responsible for the recent backlash to trade agreements.

Second, we show that the shift toward the foreign affairs paradigm has had the consequence of giving the President considerable power to declare trade wars, even though such executive actions are tantamount to making national economic policy and have significant economic consequences. This power is of particular interest, given President Trump's use of these authorities to engage in trade conflicts with both diplomatic adversaries like China and traditional US allies like Canada, Mexico, and the EU.

Third, we discuss the question of whether the President can withdraw from trade agreements without congressional participation or approval-a question that has received increased attention since President Trump's assertion that he has this power.

301. See generally Baker, supra note 178.

302. See generally Needham, supra note 1; Office of the U.S. Trade Representative, supra note 1 .

303. See generally Swanson \& Plumer, supra note 3.

304. See generally Swanson, supra note 4; Layne, supra note 3. 
Fourth, we consider the increasingly common practice of the executive branch concluding "unorthodox international agreements," and we argue that Congress's Article I powers suggest that these agreements need to be far more carefully (and narrowly) considered in the trade context.

Finally, we identify and discuss the problem of what we call "trade federalism," the fact that trade agreements increasingly threaten longstanding and core state police powers. Throughout, we compare trade policy to other areas of foreign affairs to illustrate why the case for greater congressional participation in trade policy is especially strong in trade.

\section{A. Fast Track and Congressional Oversight}

To read the legal commentary, the path from the Smoot-Hawley Tariff to the creation of fast-track authority in 1974 is the path from ridiculousness to rationality. Congress and the President came together to find a way to liberalize trade while maintaining congressional oversight. Fast-track authority, on this view, is a novel innovation that allows the government to achieve both institutional separation-of-powers goals and make good policy at the same time - a rare combination.

The view outside of the legal academy is quite different. Each time fasttrack authority (now rebranded as trade promotion authority) comes up for renewal, it is met with vehement opposition. For instance, Public Citizen, a liberal advocacy group, argues that "Fast Track empowers executive branch officials advised by large corporations to skirt Congress and the public" in making trade policies that affect a wide range of trade (i.e., employment) and non-trade (i.e., environment and public health) issues. ${ }^{305}$ When fast-track authority was last renewed in 2015 , more than two thousand groups, including dozens of labor unions, environmental groups, and human rights organizations signed a letter urging Congress not to pass fast track. In their words, the thenpending bill "does virtually nothing to increase congressional oversight over trade policymaking." 306

These very different views stem in part from baseline problems and in part from divergent views about the relative importance of preserving constitutional roles versus achieving particular policy goals. With respect to baselines, many commentators have argued that the creation of fast-track authority in 1974 represented the reassertion of congressional oversight over executive trade policy-making. ${ }^{307}$ As we explained above, however, this view is based on a

305. Fast Track: An Undemocratic Path to Unfair "Trade", PuB. CiTIZEN, https://www.citizen.org/our-work/globalization-and-trade/alternatives-corporate-globalization/fasttrack-presidential-trade [https://perma.cc/9UUV-LWGU].

306. Letter from Citizens Trade Campaign to U.S. Representatives and Senators, Re: Please Oppose "The Bipartisan Congressional Trade Priorities and Accountability Act" (Apr. 27, 2015), https://www.citizen.org/sites/default/files/fasttrackoppositionltr_042715_0.pdf [https://perma.cc/EF2L-GVBG].

307. See, e.g., Koh, supra note 9, at 1204. 
misunderstanding of Congress's role in approving trade agreements before 1974 . In granting the President authority to negotiate trade agreements, Congress has always distinguished between tariff and nontariff barriers. Up to and including the 2015 Bipartisan Congressional Trade Priorities and Accountability Act, Congress has granted the President ex ante authority to enter into reciprocal tariff-reducing agreements and to proclaim tariffs on the basis of such agreements. ${ }^{308}$

Nontariff barriers have an entirely different history. Prior to 1974, and notably in the Trade Expansion Act of 1962, Congress did not grant the President any special authority to negotiate or conclude agreements on nontariff barriers. Such agreements still had to be approved by Congress through the ordinary legislative process, open to amendment and debate in committee and on the floor. Thus, when President Johnson negotiated agreements on nontariff barriers in the Kennedy Round, he had to submit them to Congress just as he would submit any other legislation. ${ }^{309}$ In other words, congressional oversight of trade agreements on nontariff barriers was at its maximum prior to 1974, and in particular at the end of the Kennedy Round. ${ }^{310}$

Viewed against this backdrop, the fast-track procedures created by the 1974 Trade Act clearly circumscribe congressional oversight and allow the United States to more easily enter into trade agreements. Congress could not implement trade agreements as easily if members had the opportunity to introduce amendments and delay votes. So, Congress gave the President ex ante authority to conclude tariff agreements without ex post congressional approval and circumscribed its own ex post review of agreements on nontariff barriers. In other words, members of Congress lashed themselves to the mast of trade liberalization through delegations to the President. Fast-track is the culmination of this trend, not a reversal of it.

Whether this hand-tying by Congress is desirable turns, in part, on one's view of trade liberalization. Polls consistently find that those with higher levels of education are also more likely to support trade liberalization. ${ }^{311}$ It is thus perhaps not surprising that academic commentary has tended to view fast track as benign and even beneficial. Indeed, in other contexts, such as federalism,

308. See Bipartisan Congressional Trade Priorities and Accountability Act of $2015 \S 103$ (a), 19 U.S.C. § 4202(a) (2018); supra Part I.

309. See supra Part I.

310. Id.

311. See, e.g., Bradley Jones, Support for Free Trade Agreements Rebounds Modestly, but Wide Partisan Differences Remain, PEW RES. CTR.: FACTTANK (Apr. 25, 2017), http://www.pewresearch.org/fact-tank/2017/04/25/support-for-free-trade-agreements-reboundsmodestly-but-wide-partisan-differences-remain [https://perma.cc/NJ6S-5NKQ] (documenting that as education levels rise, so too does support for free trade). 
scholars have suggested that people invoke institutional arguments as pretexts to advance their preferred substantive outcomes. ${ }^{312}$

Where fast-track is concerned, though, commentators cannot have their cake and eat it too. Fast-track authority enables greater trade liberalization, but at the expense of separation-of-powers values. Moreover, as discussed above, the separation-of-powers values here reflect substantive concerns about distributional issues. ${ }^{313}$ Circumscribing congressional review of trade agreements also circumscribes the number of access points that local economic interests have to the policy-making process. In this sense, we agree that invoking institutional arguments is indeed about substantive policy preferences. It is not, however, solely or even necessarily about trade liberalization versus protectionism. Rather, by circumscribing congressional review of trade agreements, fast track modifies which views have weight in formulating trade policy. The fast-track process gives extra weight to the views of proliberalization industry advocates who participate in the US Trade Representative's industry advisory committees. ${ }^{314}$ Pushing trade agreements through the ordinary congressional process, in contrast, requires broad democratic support for the agreements. As a result, the compromise struck by fast-track legislation makes more trade agreements possible, but at the cost of reducing the political support for those agreements.

While that compromise may allow more trade agreements in the short-run, in the long-run, the lack of political buy-in for trade agreements may leave trade agreements exposed when political fortunes turn. Indeed, that appears to have been exactly what happened when political sentiment turned against trade liberalization in the United States and elsewhere in $2016 .{ }^{315}$ In other words, Congress's failure to exercise its oversight role in the short-run (in hopes of advancing trade liberalization) may in the long-run undermine trade liberalization.

\section{B. The Power to Declare Trade Wars}

The institutional home of the power to make war has been one of the most hotly contested constitutional issues of the last century. On the one hand, the President is the commander in chief of the armed forces and can respond the most quickly and decisively to a threat to American national security. ${ }^{316}$ On the other hand, the Constitution commits to Congress the legal power to declare war, appropriate money, and make regulations governing the armed forces. ${ }^{317}$

312. See, e.g., Neal Devins, The Judicial Safeguards of Federalism, 99 Nw. U. L. REv. 131, 137 (2004) ("Elected officials invoke federalism when it comports with their substantive policy preferences, but they otherwise do not care about the federal-state balance.").

313. See supra Part II.C.

314. Id.

315. See Meyer, supra note 206.

316. U.S. CONST. art. II, $\S 2$.

317. Id. art. I, $\S 8$. 
Scholars and policy-makers alike have struggled to understand how these powers should work in combination with each other in specific conflicts.

A similar problem occurs in the case of trade wars. The Constitution gives Congress broad powers over foreign commerce and tariffs. ${ }^{318}$ Yet Congress has largely delegated those powers to the President, who is already constitutionally imbued with the power to act as the nation's chief diplomat. ${ }^{319}$ Moreover, those tools that Congress previously used to constrain the executive branch's exercise of authority over trade, such as the legislative veto, have been held unconstitutional or otherwise eroded. ${ }^{320}$ Consequently, the President and the executive branch generally wield enormous power over the initiation of trade conflicts with other nations. And they do so without a widely accepted normative paradigm — foreign affairs or domestic economic policy — to guide their choices.

A trade war occurs "when a state threatens to inflict economic harm or actually inflicts it in order to persuade the target state to agree to terms of trade more favorable to the coercing state." 321 In international economic disputes, trade wars typically involve raising trade barriers against other states in order to induce them to change their policies. For instance, in January 2018, President Trump imposed so-called "safeguards" in the form of exceptional tariffs on solar cells as part of a strategy to combat the influx of Chinese-subsidized solar cells into the US market. ${ }^{322}$ In March 2018, President Trump invoked a Cold War-era law granting the President authority to impose unlimited trade restrictions on products that he determines threaten national security. Under this law, President Trump imposed a 25 percent tariff on imported steel and a 10 percent tariff on imported aluminum. ${ }^{323}$ In May and July 2018, the Trump administration also announced investigations under the same law into autos, auto parts, and

318. Id. art. I $\S 8$.

319. See, e.g., Zivotofsky v. Kerry, 135 S. Ct. 2076, 2099 (2015) (Thomas, J., concurring in part and dissenting in part) ("Upon taking office, President Washington assumed the role of chief diplomat.").

320. See supra Part I.

321. Robert A. Pape, Why Economic Sanctions Do Not Work, 22 INT'L SEC. 90, 94 (1997).

322. Press Release, Office of the U.S. Trade Representative, Exec. Office of the President, President Trump Approves Relief for U.S. Washing Machine and Solar Cell Manufacturers (Jan. 22, 2018) [hereinafter USTR Press Release, Relief for Manufacturers], https://ustr.gov/about-us/policyoffices/press-office/press-releases/2018/january/president-trump-approves-relief-us [https://perma.cc/5HD3-LF8D].

323. Doug Palmer \& Andrew Restuccia, Trump Imposes Steel and Aluminum Tariffs with Few Exceptions, POLITICO (Mar. 8, 2018), https://www.politico.com/story/2018/03/08/trumps-tariff-detailsdebated-765614 [https://perma.cc/XF8A-X64P]. The President initially granted some American allies exemptions from the tariffs while he attempted to negotiate alternative trade restrictions. By the end of May 2018, however, the President imposed the tariffs on all but four countries, three of whom faced quotas rather than tariffs. David J. Lynch, Josh Dawsey \& Damian Paletta, Trump Imposes Steel and Aluminum Tariffs on E.U., Canada, and Mexico, WASH. Post (May 31, 2018), https://www.washingtonpost.com/business/economy/trump-imposes-steel-and-aluminum-tariffs-onthe-european-union-canada-and-mexico/2018/05/31/891bb452-64d3-11e8-a69cb944de66d9e7_story.html?utm_term=.77c0f3cf8e6b [https://perma.cc/XF8A-X64P]. 
uranium. ${ }^{324}$ In public statements about these "national security" tariffs, President Trump has made plain that he views the tariffs as creating leverage in trade negotiations with partners such as the EU, Canada, and Mexico. ${ }^{325}$ In July 2018, President Trump imposed tariffs on $\$ 34$ billion worth of Chinese products. ${ }^{326}$ As of August 2018, President Trump was mulling imposing up to a 25 percent tariff on an additional $\$ 200$ billion worth of Chinese products. These moves are part of a strategy to induce China to further liberalize its economy and, in particular, to reduce pervasive government subsidies. ${ }^{327}$

Like real wars, trade wars are costly for countries that engage in them, even if they prevail. Imposing trade barriers, the primary tool of a trade war, creates real costs for the protected economy. Domestic prices of imported goods rise in response to the trade barriers, which can hurt end-use consumers and companies that rely on imported goods for their businesses. For instance, US automakers immediately reported a hit to their earnings as a result of higher steel prices in the wake of President Trump's steel tariffs. ${ }^{328}$ The steel tariffs have been a drag on other steel-reliant industries, including the oil and gas industries, which use steel for pipe. ${ }^{329}$ Economists have also worried that President Trump's imposition of 30 percent tariffs on solar panels will increase the cost of solar energy in the United States, hurting American businesses that invest in largescale solar farms and American consumers who purchase solar power. ${ }^{330}$ Industry groups have estimated that the US-imposed tariffs could cost as many

324. Ana Swanson, Trump Initiates Trade Inquiry that could Lead to Tariffs on Foreign Cars, N.Y. TiMES (May 23, 2018), https://www.nytimes.com/2018/05/23/business/trump-tariffs-foreignautos.html [https://perma.cc/CT5N-R7XX]; Ana Swanson \& Brad Plumer, U.S. Opens Investigations into Uranium Imports in Sign that Trade War is Spreading, N.Y. TIMES (July 18, 2018), https://www.nytimes.com/2018/07/18/us/politics/trump-uranium-import-probe-tariffs.html [https://perma.cc/W3CX-JEDF].

325. Jacob M. Schlesinger, Trump Cites Car-Tariff Threat as Biggest Trade Leverage, WALL ST. J. (July 2, 2018), https://www.wsj.com/articles/trump-cites-car-tariff-threat-as-biggest-tradeleverage-1530466455 [https://perma.cc/Y3PU-7M9A].

326. Ana Swanson, Trump's Trade War with China is Officially Underway, N.Y. TIMES (July 5, 2018), https://www.nytimes.com/2018/07/05/business/china-us-trade-war-trump-tariffs.html [https://perma.cc/5XAE-ZDVZ].

327. Ana Swanson \& Keith Bradsher, Chinese Goods May Face 25\% Tariffs, Not 10\%, as Trump's Anger Grows, N.Y. TIMES (Aug. 1, 2018), https://www.nytimes.com/2018/08/01/business/china-tariffs-trump.html [https://perma.cc/5EFC$7 \mathrm{MDE}]$.

328. Matthew DeBord, It Didn't Take Long for Trump's Tariffs to Become Headache for the Auto Industry, BUS. INSIDER (July 25, 2018), https://www.businessinsider.com/trump-tariffs-becomeheadache-for-auto-industry-2018-7 [https://perma.cc/8Y2Q-QKLB].

329. Chris Tomlinson, President Donald Trump's Steel Tariffs Holding Back Oil and Gas Industry Growth, HOustON CHRON. (July 23, 2018), https://www.houstonchronicle.com/business/columnists/tomlinson/article/President-Donald-Trump-ssteel-tariffs-holding-13092692.php [https://perma.cc/F86D-6ZYF].

330. Ana Swanson \& Brad Plumer, Trump Slaps Steep Tariffs on Foreign Washing Machines and Solar Products, N.Y. Times (Jan. 22, 2018), https://www.nytimes.com/2018/01/22/business/trumptariffs-washing-machines-solar-panels.html [https://perma.cc/4C79-RKFR]. 
as twenty-three thousand jobs in the United States. ${ }^{331}$ This estimate is broadly consistent with the net job loss associated with past efforts to protect the US economy. ${ }^{332}$ Apart from these direct effects of US-imposed trade barriers, other countries may respond with retaliatory trade barriers on US exports, as numerous countries have done in response to President Trump's tariffs. ${ }^{333}$ These increased trade barriers depress prices for US exporters. ${ }^{334}$

Given the significant economic costs associated with trade wars, it would make sense for Congress - the constitutional repository for authority over the economy - to wield primary responsibility for initiating trade wars. In fact, our current statutory framework allocates that power principally to the executive branch. The executive wields at least two sets of powers that are largely free of congressional oversight. First, as discussed above, the President controls the United States' actions at the WTO and within other international trade agreements. ${ }^{335}$ As a consequence, the President, acting through the US Trade Representative, determines what kinds of trade cases to bring against our trading partners. These cases often form the basis for trade wars. For instance, if the United States is successful in a WTO case and the other party does not comply with the WTO's ruling, the United States can lawfully raise its trade barriers. ${ }^{336}$ The President exercises this authority as a matter of domestic law. Indeed, in passing the URAA, Congress concerned itself primarily with cases in which the United States was a respondent, i.e., a defendant ${ }^{337}$ In those cases, the President was required to consult with Congress and any affected states. ${ }^{338}$ But Congress imposed no limits on the President's use of offensive authorities in the URAA, leaving the President with considerable authority to initiate trade wars through the WTO mechanism..$^{339}$

Second, the President, and the executive branch more generally, administers and to a large extent controls the nation's trade remedies and

331. Oliver Milman, Trump's Tariffs on Panels Will Cost US Solar Industry Thousands of Jobs, THE GUARDIAN (Jan. 24, 2018), https://www.theguardian.com/environment/2018/jan/23/donaldtrump-tariffs-solar-panels [https://perma.cc/3XDZ-M62Q] (quoting the Solar Energy Industries Association's figure for potential job loss).

332. See, e.g., Gary C. Hufbauer \& Ben Goodrich, Steel Policy: The Good, the Bad, and the Ugly, in INTERNATIONAL ECONOMiCS AND INTERNATIONAL ECONOMIC POliCY 24, 25 (Philip King et al. eds., 4th ed. 2005) (estimating that the 2002 US steel tariffs cost $\$ 400,000$ annually per steel job saved and resulted in net job losses within the United States).

333. Alix Langone, These U.S. Exporters will be Hardest Hit by Retaliatory Tariffs: Here Is a List of Everyday U.S. Exports That Could Cost More Because of Trump's Trade War, TIME MONEY (June 13, 2018), http://time.com/money/5304493/us-exports-tariffs-list [https://perma.cc/B2TBGB5D].

334. See, e.g., Jeff Daniels, Fall in Soybean Prices Leave Farmers Struggling, CNBC (July 12, 2018), https://www.cnbc.com/2018/07/12/fall-in-soybean-prices-from-china-trade-spat-leavesfarmers-struggling.html [https://perma.cc/YSY2-WY95].

335. See supra Part I.

336. DSU, supra note 160, art. 22.

337. See URAA §§ 121-130, 19 U.S.C. §§ 3531-3540 (2018).

338. Id.

339. Id. 
enforcement laws. For separation-of-powers purposes, such laws can be usefully divided into two groups: (1) antidumping and countervailing duty investigations, and (2) safeguards (Section 201 investigations), ${ }^{340}$ national security investigations (Section 232 investigations), ${ }^{341}$ and retaliatory trade sanctions investigations (Section 301 investigations). ${ }^{342}$ Antidumping duties are tariffs on products that are being sold at below fair market value; countervailing duties are tariffs imposed on goods that benefit from certain foreign government subsidies. ${ }^{343}$ Nations regularly use antidumping or countervailing duties on a titfor-tat basis to induce each other to grant greater market access or to protect their own sensitive domestic industries. ${ }^{344}$ But antidumping and countervailing duty investigations do not raise significant separation-of-powers issues. Congress has prescribed how and when the executive may impose such duties and subjected their imposition to judicial review. ${ }^{345}$ Furthermore, private parties normally initiate antidumping and countervailing duty investigations. ${ }^{346}$ The executive branch does, however, have the statutory authority to "self-initiate" such investigations. ${ }^{347}$ Although the executive rarely uses this authority, doing so is tantamount to declaring a trade war, because initiating investigations will likely lead to the imposition of duties that American business itself did not seek. Once again, President Trump made use of this authority by self-initiating investigations into Chinese aluminum. ${ }^{348}$ The last time the US government selfinitiated an investigation was in 1985, when the US targeted Japanese semiconductors during a period of trade tensions between the two countries. ${ }^{349}$

The second category of trade laws involves much more expansive delegations of authority to the President, with far fewer checks. Under each of these laws, the President has significant discretion as to what kind and level of

340. Trade Act of $1974 \S 201,19$ U.S.C. $\$ 2252$ (2018).

341. Trade Expansion Act of $1962 \S 232$, 19 U.S.C. $\$ 1862$ (2018).

342. Trade Act of 1974, § 301, 19 U.S.C. $\$ 2411$.

343. Wentong Zhang, Reforming Trade Remedies, 34 MiCH. J. INT’L L. 151, 153 (2012).

344. See Chad P. Bown, Trade Remedies and World Trade Organization Dispute Settlement: Why Are So Few Challenged?, 34 J. LEGAL STUD. 515, 524 (2005) (describing the use of trade remedies as "vigilante justice").

345. In other countries, antidumping and countervailing duty investigations are more under the thumb of the government. See Wee, infra note 356 (noting that the Chinese government had "teed up" the sorghum antidumping and countervailing duty investigations).

346. Jennifer McCadney, In Rare Move, Trump's Commerce Secretary Self-Initiates Chinese Aluminum Trade Remedy Cases, TRADE \& MANU. MONITOR (Nov. 30, 2017), https://www.ustrademonitor.com/2017/11/in-rare-move-trumps-commerce-secretary-self-initiateschinese-aluminum-trade-remedy-cases [https://perma.cc/Z4B7-XV5V].

347. Shawn Donnan, US Initiates Anti-dumping Investigation into Chinese Aluminum Sheeting Imports, Fin. TIMES (Nov. 28, 2017), https://www.ft.com/content/6d986086-3928-3678-943f938179b35a94 [https://perma.cc/KN9A-KX7N].

348. Press Release, U.S. Dep't of Commerce, U.S. Department of Commerce Self-Initiates Historic Antidumping and Countervailing Duty Investigations on Common Alloy Aluminum Sheet From China (Nov. 28, 2017), https://www.commerce.gov/news/press-releases/2017/11/us-departmentcommerce-self-initiates-historic-antidumping-and [https://perma.cc/VN8C-3M55].

349. Donnan, supra note 347. 
trade barrier to impose, on which products, from which countries, and for how long. Moreover, the President's exercise of discretion under these laws is subject to limited judicial review at best. ${ }^{350}$ The safeguards process, for example, does not provide a meaningful check on presidential discretion. Safeguards are "restrictions on imports imposed in the event of import surges to allow domestic industries of the importing country to make positive adjustments to import competition." 351 Following a domestic investigation, the ITC must determine that safeguards are warranted, then recommend the form those safeguards should take. The President, however, need not follow the ITC's recommendation.

President Trump's recent imposition of tariffs on solar panels illustrates the point. After making the requisite findings of injury, the ITC suggested three possible remedies: tariffs, quotas, and import licensing fees. ${ }^{352}$ Industries that benefit from cheap solar imports (including solar installers and their customers) lobbied the White House aggressively in an effort to get the President to reject the ITC's recommendations. ${ }^{353}$ Instead, the President imposed tariffs on solar panels and, in a separate investigation, on washing machines. ${ }^{354} \mathrm{He}$ did so despite opposition from the governors of a number of states and multiple members of Congress, who wrote to express opposition to the safeguards. ${ }^{355}$ In a surprise to no one, China - the primary target of the solar tariffs - responded by initiating an investigation into American sorghum, a grain used in food and in the

350. Neither Section 201 nor Section 232 nor Section 301 expressly provides for judicial review. Moreover, the Supreme Court has held that the President is not an "agency" within the meaning of the Administrative Procedure Act (APA), meaning that the APA is not available as an avenue for judicial review of the President's final decision. See Dalton v. Specter, 511 U.S. 462 (1994); Franklin v. Mass., 505 U.S. 788 (1992). However, the APA might be available to review any necessary determinations made by administrative agencies like the Commerce Department. See Bennett v. Spear, 520 U.S. 154, 177-78 (1997) (holding that agency action is "final" and hence reviewable for APA purposes if, inter alia, it merely "alter[s] the legal regime" pursuant to which subsequent government action takes place). Some have argued that courts should infer the power to review whenever the President has at least acted within the statutory criteria, even if more searching APA review of the President's exercise of discretion is unavailable. See Erwin P. Eichmann \& Gary N. Horlick, Political Questions in International Trade: Judicial Review of Section 301? 10 MICH. J. INT”L L. 735, 743 (1989) (“Even though Congress did not specify that Section 301 was intended to be subject to judicial review, the courts may legitimately infer such a requirement.").

351. Zhang, supra note 343, at 153.

352. Krysti Shallenberger, ITC Proposes 3 Solar Trade Case Remedies with Tariffs, Quotas and Capped Imports, UTILITY DIVE (Oct. 31, 2017), https://www.utilitydive.com/news/itc-proposes-3solar-trade-case-remedies-with-tariffs-quotas-and-capped-im/508596 [https://perma.cc/2368-XCQ6].

353. Lacey Johnson, Industry Leaders Make Last-Ditch Effort to Steer Trump White House Away From Solar Tariffs, GREENTECH MEDIA (Jan. 12, 2018), https://www.greentechmedia.com/articles/read/solar-industry-makes-last-ditch-lobbying-against-solartariffs [https://perma.cc/W9RB-C658].

354. USTR Press Release, Relief for Manufacturers, supra note 322.

355. Lacey Johnson \& Julia Pyper, Solar Tariff Case Advances as ITC Finds 'Injury', GREENTECH MEDIA (Sept. 22, 2017), https://www.greentechmedia.com/articles/read/solar-trade-caseadvances-as-itc-finds-injury [https://perma.cc/X96N-ZZL5]. 
production of syrup. ${ }^{356}$ China's investigation targeted an agricultural product that is important to President Trump's political base and is primarily exported to China. ${ }^{357}$

Likewise, under Section 301 of the 1974 Trade Act, Congress has authorized the President to "suspend, withdraw, or prevent the application of . . . benefits of trade agreement[s]" with any country that, in the President's view, maintains "unjustifiable or unreasonable" trade barriers. ${ }^{358}$ The legislative veto was designed to limit the President's discretion to deviate from the ITC's recommendations in the case of safeguards investigations or to override the President's decisions in Section 301 investigations. However, after Chadha, the legislative veto can no longer check the President. ${ }^{359}$

As of August 2018, President Trump had used that authority to impose a 25 percent tariff on $\$ 50$ billion worth of Chinese imports, causing China to impose a reciprocal 25 percent on $\$ 50$ billion worth of US exports. ${ }^{360}$ Initially, President Trump considered using the same Section 301 authority to impose restrictions on Chinese investment in the United States. However, the administration ultimately decided to delay investment restrictions until Congress passed new legislation expanding the authority of the Committee on Foreign Investment in the United States (CFIUS) to impose such measures. ${ }^{361}$

The broadest grant of authority comes from Section 232 of the Trade Expansion Act of 1962. This Act provides the basis for the President's 25 percent tariff on steel and 10 percent tariff on aluminum, as well as for investigations into autos, auto parts, and uranium. The Act permits the President "to take action to adjust imports of an article" that the Secretary of Commerce has determined presents a threat to national security. ${ }^{362}$ The President's discretion under Section 232 is virtually unlimited. The statute does not restrict the kind of trade barrier the President may choose, as trade remedies laws do, nor does it impose limits on the duration of the trade restriction. In principle, the law requires the President to act only when necessary to curb the threat to national security. ${ }^{363}$ But the law's definition of national security includes

356. Sui-Lee Wee, China's Trade Investigation Takes Aim at Trump's Voter Base, N.Y. TIMES (Feb. 5, 2018), https://www.nytimes.com/2018/02/05/business/china-us-trade-sorghum.html [https://perma.cc/ZD78-EDFZ] ("It is already a partial trade war.").

357. Id.

358. Trade Act of $1974 \S 301,19$ U.S.C. $\S 2411$ (2018).

359. See supra Part I.

360. Bob Bryan, Round 2: US, China Announce Newest Round of Tariffs as Trump's Trade War Shows No Sign of Slowing Down, BuS. INSIDER (AUG. 8, 2018), https://www.businessinsider.com/trump-tariffs-china-trade-war-chinese-goods-2018-8 [https://perma.cc/9WVV-2X5D].

361. Shawn Donnan, Trump Drops New Restrictions on China Investments, FIN. TIMES (June 27, 2018), https://www.ft.com/content/a819ec8a-79f4-11e8-8e67-1e1a0846c475 [https://perma.cc/UNL9-BFB4].

362. Trade Expansion Act of $1962 \S 232(\mathrm{c})(1)(B), 19$ U.S.C. $\S 1862(\mathrm{c})(1)(\mathrm{B})(2018)$

363. Trade Expansion Act of $1962 \S 232(\mathrm{c})(1)(\mathrm{A})(\mathrm{ii}), 19$ U.S.C. $\S 1862(\mathrm{c})(1)(\mathrm{A})(\mathrm{ii})$. 
the impact of foreign competition on the economic welfare of individual domestic industries; and any substantial unemployment, decrease in revenues of government, loss of skills or investment, or other serious effects resulting from the displacement of any domestic products by excessive imports shall be considered, without excluding other factors. (emphasis added). ${ }^{364}$

In other words, the Secretary of Commerce and ultimately the President may consider virtually any factor as part of "national security." Indeed, after imposing global tariffs on steel and aluminum under Section 232, President Trump summarily announced that he would double the "national security" tariffs on Turkey alone - in part to secure the release of a detained American pastor. ${ }^{365}$

Because presidents have control over what type of WTO cases to bring, as well as overwhelming influence over domestic trade laws, they can launch a trade war without congressional consent. Whether this state of affairs is desirable is a normative question that parallels the analysis of the war powers question in many respects. But there are at least two important differences. First, trade conflicts rarely involve the kinds of immediate risks to national security that may necessitate presidential action in the context of shooting wars. Second, the President's authority to initiate trade wars is more clearly established than the authority to initiate shooting wars. Still, as with the debate about shooting wars, ceding authority to the President has reduced the number of veto points involved in starting a conflict. This increases the likelihood of decision-making based on systematic errors of judgment, makes it easier to become involved in conflicts, and reduces the degree of democratic participation in the decision. ${ }^{366}$

Whether this results in better policy outcomes likely depends on how one feels about the trade war in question and the extent to which any given administration is susceptible to systematic biases. Our chief point, however, is that Congress's delegation of power to the executive branch in the trade context changes the kinds of policy outcomes we would expect when compared to the separation of powers baseline. Congress is subject to a wider variety of pressures than the President, who, once elected, has a freer hand to privilege certain constituencies at the expense of others. ${ }^{367}$

Indeed, in recognition of this fact, members of Congress have introduced a number of bills that would return to Congress the ultimate decision to raise trade barriers. ${ }^{368}$ These bills would, in effect, shift the burden of initiating trade wars

364. Trade Expansion Act of $1962 \S 232(d), 19$ U.S.C. $§ 1862(d)$.

365. Thomas Franck, Trump Increases Pressure on Turkey Amid Currency Crisis, Authorizes Doubling of Metals Tariffs, CNBC (Aug. 10, 2018), https://www.cnbc.com/2018/08/10/trump.html [https://perma.cc/WRC4-GXA9].

366. On how executive power might lead to systematic biases and errors of judgment in the war powers context, see Ganesh Sitaraman \& David Zionts, Behavioral War Powers, 90 N.Y.U. L. REV. $516(2015)$.

367. See supra Part II.

368. Kathleen Claussen, Trade War Battles: Congress Reconsiders its Role, LAWFARE (Aug. 5, 2018), https://www.lawfareblog.com/trade-war-battles-congress-reconsiders-its-role 
to Congress. Under the current framework, the President can take action without congressional consent, and Congress must affirmatively act through the legislative process to override the President's decision. Because the President would presumably veto any override bill, an override vote would require a twothirds majority in each house. Under proposed legislation, however, a simple majority of Congress could impose trade barriers and block the adoption of new trade barriers. Such a proposal would greatly expand Congress's role in determining when and how to start a trade war.

For instance, under a bill proposed by Republican Senator Bob Corker, the President's determination of what action to take under Section 232 in response to a national security threat posed by imports would take the form of a proposal to Congress. ${ }^{369}$ Congress's decision on the President's proposal would be subject to fast-track procedures, guaranteeing the President an up-or-down vote. Unlike the original introduction of fast-track procedures in 1974, which circumscribed congressional review of trade agreements on nontariff barriers, Senator Corker's proposal would expand congressional review. Moreover, this expansion takes into account the necessity of speedy action from Congress, informed by guidance from the executive branch, in a true national security situation.

\section{Withdrawing from Trade Agreements}

Since President Donald Trump took office in January 2017, the question of whether the President can unilaterally withdraw from trade agreements has garnered considerable attention. The President has at various times claimed that he will terminate the North American Free Trade Agreement (NAFTA) and the United States-Korea Free Trade Agreement (KORUS) unless they are renegotiated on more favorable terms for Americans. ${ }^{370} \mathrm{He}$ has also reportedly indicated that he would like to withdraw from the World Trade Organization (WTO), ${ }^{371}$ which his US Trade Representative has criticized as departing from the bargain struck by the WTO contracting parties. ${ }^{372}$

[https://perma.cc/J4VZ-2VQ7] (describing various bills pending in Congress to rein in the President's authority to raise trade barriers).

369. See S. 3013, 115th Cong. (2018).

370. Ken Thomas, Trump, Trudeau Meet at the White House Amid New NAFTA Talks, WASH. POST (Oct. 11, 2017), https://www.usnews.com/news/world/articles/2017-10-11/trump-trudeau-meetat-the-white-house-amid-new-nafta-talks [https://perma.cc/2J9B-YLNK]; Damian Paletta, Trump Preparing Withdrawal from South Korea Trade Deal, a Move Opposed by Top Aides, WASH. PosT (Sept. 2, 2017), https://www.washingtonpost.com/news/wonk/wp/2017/09/02/trump-planswithdrawal-from-south-korea-trade-deal/?noredirect=on\&utm_term=.37cd6ec85892 [https://perma.cc/DW39-XVZV].

371. Doina Chiacu \& Jeff Mason, Trump Threatens Action on WTO after Reports He Wants to Withdraw, REUTERS (July 2, 2018), https://www.reuters.com/article/us-usa-trade-wto-ross/trumpthreatens-action-on-wto-after-reports-he-wants-to-withdraw-idUSKBN1JS194 [https://perma.cc/32U7-NPQE].

372. See Dispute Settlement Body, World Trade Org., Draft Annual Report II 2.2 (2017) (noting concerns by WTO members with "linking the discussion of the systemic issues raised by the United States to the Appellate Body selection process."), 
Foreign relations scholars, however, have come to different conclusions on this question. Some argue that the President cannot terminate agreements unilaterally. They cite the silence of the constitutional text and point to historical practices of the early republic, in which Congress played a much larger role in treaty termination. ${ }^{373}$ They also analogize treaties to statutes, which are terminated through the same process by which they are created. ${ }^{374}$ Others argue that the President can terminate treaties unilaterally. They argue that Article II of the Constitution grants the President broad executive and foreign affairs powers, and that more recent practice supports this authority. ${ }^{375}$ Still others have suggested a middle way, postulating that termination powers might depend on the subject matter of the treaty at hand. ${ }^{376}$

In our view, the allocation of the power to terminate the United States' international obligations depends both on the constitutional allocation of authority among the branches and on how that authority has actually been exercised. We therefore think the most productive way to determine whether the President can withdraw from an international agreement (trade or otherwise) is first to ask whether Congress could constitutionally restrict the President's ability to withdraw. That answer, we contend, depends on the constitutional allocation of authority over the relevant subject matter. As we explain below, Congress could restrict the President's authority to withdraw from trade agreements, although perhaps not his ability to withdraw from other kinds of agreements that implicate specific Article II powers.

The question of withdrawal is of critical importance because it implicates the balance of power between Congress and the President. If the President can withdraw from trade agreements without congressional consent, then Congress's

https://docs.wto.org/dol2fe/Pages/FE_Search/FE_S_S009_

DP.aspx?language $=E \&$ CatalogueIdList $=239436,239419,239440,239442,239441,239443,239413,239$ 407,239408,239412\&CurrentCatalogueIdIndex=5\&FullTextHash=371857150\&HasEnglishRecord=T rue\&HasFrenchRecord=True\&HasSpanishRecord=True [https://perma.cc/58QN-7F8F].

373. See generally Joel P. Trachtman, Power to Terminate U.S. Trade Agreements: The Presidential Dormant Commerce Clause Versus a Constitutional Gloss Half Empty 20-22 (unpublished manuscript), https://papers.ssrn.com/sol3/papers.cfm?abstract_id=3015981 [https://perma.cc/K6BB47JW].

374. DAVID Gray Adler, The CONSTItUtion AND the Termination OF Treaties 250 (1986) (arguing that the Goldwater v. Carter Court "should have held that a treaty can be terminated only by the treaty-making power, to wit, the President and the Senate"); see also Raoul Berger, The President's Unilateral Termination of the Taiwan Treaty, 75 Nw. U. L. REv. 577 (1980); Michael J. Glennon, The Senate Role in Treaty Ratification, 77 AM. J. INT'L L. 257, 262 n.36 (1983) (describing this position).

375. See, e.g., John C. Yoo, Review Essay, Politics as Law?: The Anti-Ballistic Missile Treaty, the Separation of Powers, and Treaty Interpretation, 89 CALIF. L. REV. 851, 873-74 (2001) ("[M]ost commentators, courts, and government entities believe that the President may terminate a treaty unilaterally. The President retains this authority due to his leadership in foreign affairs ... and his structural superiority in conducting international relations.").

376. For a discussion of this position and a helpful overview of other positions in the debate, see Kristen E. Eichensehr, Treaty Termination and the Separation of Powers, 53 VA. J. INT'L L. 247, 256 n.32 (2013). 
role in trade policy is further minimized. In the current political climate, this would significantly impair Congress's ability to protect trade agreements. More generally, having no role in withdrawal would limit Congress's leverage over the President in renegotiating trade agreements. The President would have the ability to present Congress with a revised trade agreement that was, in Congress's view, worse than the existing agreement but better than nothing at all. If the President's threat to terminate the existing agreement were credible, Congress would be forced to accept what it viewed as an even worse trade agreement. With the ability to veto a withdrawal, though, Congress would only accept agreements which it viewed as superior to the existing agreement.

\section{Restricting Presidential Power to Withdraw}

Consider first whether Congress can restrict the President's power to withdraw from trade agreements. One can easily imagine Congress, in the process of implementing a trade agreement, writing into legislation that the President cannot withdraw from international obligations barring certain triggering conditions, or that the President cannot withdraw from the agreement under any circumstances.

Given the absence of express constitutional text as to how the United States should withdraw from its international commitments, courts would evaluate claims about the allocation of such authority under Justice Jackson's famous typology from Youngstown Sheet \& Tube v. Sawyer. ${ }^{377}$ In the trade context, congressionally imposed restrictions on the President's ability to withdraw would fall into Youngstown category three, in which the President can only triumph over Congress if the President's power is exclusive or preclusive. ${ }^{378}$ Such cases are comparatively easy. ${ }^{379}$ The text of Article I expressly grants Congress the power "to regulate commerce with foreign Nations." Historical practice from the early republic also indicates congressional involvement in treaty withdrawal and termination. ${ }^{380}$ In comparison with the express textual grant and early historical evidence supporting congressional authority, the case for a preclusive presidential power rooted in either "the executive power" or "foreign affairs" power seems extremely weak. Notably, the text of Article II does not specify that these powers belong to the executive.

Indeed, from a foreign relations law perspective, trade agreements are all congressional-executive agreements (CEAs), rather than Article II treaties. Congress uses the ordinary legislative process to consent to international

377. Youngstown Sheet \& Tube v. Sawyer, 343 U.S. 579 (1952); see also Zivotofsky v. Kerry, 135 S. Ct. 2076 (2015).

378. Id. at 637-38.

379. Other substantive areas might be more difficult. For instance, the President would have a much stronger case that Congress could not prevent him from withdrawing from agreements regarding military bases or agreements contingent on recognizing a foreign state, since these are core Article II powers. See Zivotofsky, 135 S. Ct. at 2076.

380. Bradley, supra note 10. 
commitments via CEAs. That is, congressional consent to international obligations created through CEAs rests on Congress's enumerated powers under Article I, §8. Congress can therefore use those same powers to impose restrictions on the President's ability to withdraw from the international commitments to which it consents. ${ }^{381}$

Functional arguments also suggest that Congress should have the power to constrain withdrawal from trade agreements. Traditionally, functionalists have justified expansive presidential power based on the uniqueness of foreign affairs with respect to expertise, secrecy, subject matter, error cost, speed, and flexibility. As we have demonstrated, however, most of these arguments are comparatively unpersuasive in the trade agreement context. Trade agreements deal with economic and regulatory subjects. Such matters are commonly understood as within Congress's purview and, indeed, are constitutionally committed to Congress in Article I. Given the way the government is set up, the executive branch will have greater expertise in virtually all areas of policymaking. And in general, treaty withdrawal will not raise any issues that require secrecy.

Speed and flexibility provide relatively stronger grounds for a preclusive presidential power. Conditions might change after the agreement is adopted. For example, the outbreak of war between two trading partners might force the United States to choose sides by breaking trade relations with one country. In such a case, speed and flexibility favor presidential decision. But for these functional arguments to override an express statutory provision that Congress deliberated upon and passed (and that the President likely signed, absent a veto override), courts would have to find the speed and flexibility justifications so persuasive as to amount to a preclusive or exclusive executive power to withdraw. Given the subject matter of trade agreements and the textual commitment of authority to Congress in Article I, this seems unlikely. ${ }^{382}$

\section{Implicit and Explicit Authorizations to Withdraw}

On the other end of the spectrum are cases in which Congress has authorized the President to withdraw from trade agreements. Authorizations come in two forms: explicit and implicit. Explicit authorizations involve Congress affirmatively granting the President power to withdraw from a trade agreement. Trade acts in the middle of the twentieth century included a provision requiring the President to include a withdrawal or termination clause in trade

381. At least arguably, Congress's power to use its Article I powers to restrict withdrawal from Article II treaties - consented to by the Senate and more firmly rooted in the President's constitutional role as the nation's chief diplomat - might be more limited.

382. One exception, however, might be trade agreements terminated pursuant to a recognized Article II power, such as the President's recognition power. In Zivotofsky, the Court held that the President has a preclusive recognition power. As a result, it may be that Congress's power to limit the President's ability to withdraw from a trade agreement is itself limited in the narrow context of a case in which the President de-recognizes a foreign country and the withdrawal is incidental to de-recognition. 
agreements that reduced tariffs. ${ }^{383}$ Moreover, these provisions authorized the President to withdraw tariff proclamations made pursuant to such agreements, effectively giving the President the power to withdraw from any tariff-reduction agreement. ${ }^{384}$

Implicit authorizations do not expressly grant withdrawal powers. Rather, implicit authorizations flow from ordinary statutory interpretation tools applied to the implementing legislation Congress passes to approve trade agreements. At first glance, such provisions seem unproblematic. Congressional authorization to withdraw from a trade agreement is a Youngstown category one case: the President has all the power Congress can delegate (including, in such a case, the Article I foreign commerce power) in addition to Article II executive powers.

However, implicit authorizations can create a variety of problems and paradoxes. Consider, for instance, the sunset provisions that Congress has included in all implementing legislation for trade agreements since NAFTA. ${ }^{385}$ Congress generally provides that the implementing legislation "will cease to have effect" when the United States ceases to be a party to the agreement. ${ }^{386}$

These sunset provisions are best read to grant implicit withdrawal authority to the President. The trade agreements in question each include a provision permitting a party to withdraw after six months' written notice. ${ }^{387}$ The Constitution and courts presume that Congress knows the contents of the international agreements it approves. Yet Congress's implementing legislation

383. See, e.g., Trade Expansion Act of 1962 § 255(a); 19 U.S.C. § 1884(a) (2018).

384. Trade Expansion Act of $1962 \S 255$ (b), 19 U.S.C. $§ 1884($ b).

385. NAFTA's equivalent provision, Section 109 of the NAFTA Implementation Act, is less clear. It provides: "During any period in which a country ceases to be a NAFTA country, sections 101 through 106 shall cease to have effect with respect to such country." This provision at least arguably does not apply to a US withdrawal, since it would not make sense to talk about the NAFTA Implementation Act ceasing to have effect with respect to the United States. The provision also does not expressly sunset the entire Implementation Act, as subsequent implementation acts do. However, Section 101 contains Congress's consent to the agreement entering into force. Section 109 thus operates to withdraw congressional consent to applying the treaty to parties that have withdrawn. Arguably, this could include application of the Implementation Act in its entirety. More generally, in NAFTA, as in all subsequent trade implementation acts, Congress legislated knowing (a) the United States had the option to withdraw under the treaty, and (b) that the President had in recent times exercised such options unilaterally.

386. United States-Korea Free Trade Agreement Implementation Act $§ 107(\mathrm{c})$, Publ. L. No. $112-$ 41, 125 Stat. 432 (2011) [hereinafter KORUS]; see also Dominican Republic-Central America-United States Free Trade Implementation Act § 107(d), Publ. L. No. 109-53, 119 Stat. 466 (2005). To be sure, these sunset provisions cover situations in which other parties withdraw. However, they also apply to withdrawals by the United States. Section 107(d) of the CAFTA Implementation Act, for example, explicitly states that the Act shall sunset when the Agreement ceases to be in force for the United States. A different provision, Section 107(c), provides that the legislation ceases to have effect for other parties that withdraw. The KORUS Implementation Act provides that the legislation sunsets when KORUS itself "terminates." KORUS supra. Since KORUS is a bilateral treaty, the treaty terminates whenever either party withdraws. Id. Had Congress intended for the sunset only to apply to a Korean withdrawal, it could easily have written Section 107(c) to make that clear. See id.

387. See, e.g., Central American Free Trade Agreement art. 22.7, Aug. 5, 2004, 43 I.L.M. 514 (2004). 
makes no provision for how the United States may exercise an exit option; it further provides that if the United States ceases to be a party, the implementing legislation shall automatically cease to have effect. If Congress did not think the President could terminate the United States' international obligations unilaterally, then it would be unnecessary for the statutory implementation provisions to sunset. Congressional authorization to withdraw would supersede the sunset provision.

Hence, it appears that the President has statutory authority to withdraw from most modern trade agreements. For reasons we note above, this authority further minimizes the role of Congress in formulating trade policy, and therefore in making significant policy choices that affect the domestic economy. For instance, if President Trump can terminate NAFTA without Congressional consent, he can modify the economic rules under which major sectors of the American economy, including the auto and agricultural industries, operate and upon which they rely.

However, these sunset provisions also raise constitutional concerns. In Clinton v. New York, the Supreme Court held the line-item veto unconstitutional under the Presentment Clause because a line-item veto gave the President the power to unilaterally repeal or amend portions of a statute. ${ }^{388}$ The sunset provisions contained in trade agreements potentially suffer from the same problem. If the President can unilaterally withdraw from an international agreement, and the unilateral withdrawal effects a repeal of a domestic statute (the implementing legislation), then Congress may have impermissibly delegated to the President the power to repeal a statute. In this sense, the delegation of withdrawal authority runs up against the outer constitutional limits of Congress's ability to delegate trade lawmaking to the President. As long as Congress continues to pass legislation to implement trade agreements, the Constitution will not allow Congress to give the President the power to cancel those agreements.

There are, however, at least two potential distinctions between the sunset clauses in these statutes and the Line Item Veto Act at issue in Clinton v. New York. First, courts may treat delegations of authority to the President differently when the delegated power implicates foreign affairs. ${ }^{389}$ Moreover, as Professor Ed Swaine noted, courts have generally treated assimilative delegations-where a predicate act by an entity other than Congress alters the application of a federal

388. Clinton v. City of New York, 524 U.S. 417 (1998).

389. For example, even Justice Sutherland and the four horsemen upheld the international delegation in U.S. v. Curtiss-Wright. U.S. v. Curtiss-Wright Export Corp., 299 U.S. 304 (1936). Note, however, that Curtiss-Wright dealt with the application of the nondelegation doctrine to an international delegation, while Clinton v. New York found that the delegated authority violated the Presentment Clause, rather than the nondelegation doctrine. Looked at this way, trade agreements resemble the Presentment Clause issue in Clinton v. New York more than they resemble the traditional nondelegation issues at issue in Curtiss-Wright. 
law-as unproblematic. ${ }^{390}$ Second, the line-item veto involved the repeal of only a portion of the statute, whereas withdrawal tied to a sunset clause repeals the entire statute. On the one hand, this might suggest the legitimacy of the sunset clause because the legislative bargain isn't broken in a piecemeal fashion. On the other hand, sunset clauses allow the President to unilaterally repeal a statute altogether, which goes against the formal understanding of bicameralism and presentment underlying the decision in Clinton v. New York.

Perhaps paradoxically, the very statutory provision that implicitly grants the President authority to withdraw from an international agreement also unconstitutionally repeals a domestic statute. It is not clear what to make of this. The provision could be constitutional as applied to granting the President power to withdraw from the international commitments, because Congress intended the President to have that power, but unconstitutional as applied to the statutory repeal. This would leave the domestic obligations of the United States in place, while the President could still terminate the international obligations.

The upshot would be that, absent an affirmative congressional repeal, the President would still be responsible for implementing a trade agreement to which the United States would no longer be party. ${ }^{391}$ This result is perhaps most likely in the case of the WTO. Unlike the implementing legislation for free trade agreements, the URAA does not contain a clause sunsetting the legislation upon a withdrawal. ${ }^{392}$ In many if not most contexts, this situation would still alter how the executive could legally behave. Implementing legislation does not simply direct the President to comply with the terms of the agreement, nor does it directly enact the agreement into the US Code. For instance, Section 125 of the Trade Act of 1974, which applies to subsequent trade agreements, provides that the President may immediately raise tariffs to the level they would otherwise be at after withdrawing from a trade agreement. ${ }^{393}$ Consequently, the President could arguably raise tariffs to WTO levels after withdrawing from a free trade agreement such as NAFTA.

A second possibility, suggested by Professor Joel Trachtman, is that constitutional avoidance dictates reading the sunset provision as requiring affirmative congressional consent to withdraw from NAFTA. ${ }^{394}$ In other words,

390. Edward T. Swaine, The Constitutionality of International Delegations, 104 COLUM. L. REV. 1492,1519 (2004).

391. In fact, such a situation is not so odd. The United States frequently adheres to international instruments that are not legally binding on it, including through statutes that reference nonbinding instruments. Examples include SALT II, the Basel Accords on Capital Adequacy, and the Kimberly Process on conflict diamonds.

392. Indeed, far from authorizing presidential withdrawal, section 125 of the URAA arguably establishes a procedure by which Congress can direct the president to withdraw. URAA $\S 125(\mathrm{~b}), 19$ U.S.C. §3535(b) (2018) (establishing a procedure by which Congress expresses its disapproval of the WTO).

393. Trade Act of $1974 \S 125(\mathrm{e}), 19$ U.S.C. $§ 2135$ (2018).

394. Trachtman, supra note 373, at 20-22 ("implementing statutes that provide for termination of the statute upon termination of the agreement are even more difficult to interpret as implicitly 
the sunset provision would not be unconstitutional under Clinton v. New York if Congress had to authorize the President to withdraw from NAFTA first. Congress's authorization would be the effective act repealing the implementation act. This argument has at least two difficulties. First, from a formalist point of view, the President's withdrawal is still the act that effects the repeal. Second, and more problematically, on this reading the sunset provision operates like an affirmative restriction on the President's ability to withdraw. This runs contrary to Congress's apparent intent to allow the legislation to sunset without further congressional action. Were it not for the sunset provision, the President could arguably withdraw from the agreement without automatically (and unconstitutionally) effecting the repeal of a statute. The avoidance canon does not make any interpretation of a provision available, and a reading that appears flatly contradicted by the provision in question seems out of bounds.

\section{No Authorization to Withdraw}

Yet a third possibility is that the provision is unconstitutional and therefore should simply be ignored. Assuming the provision is severable, that raises the question of what happens when there is no indication one way or another of whether Congress authorized withdrawal.

There are cases in which trade implementing legislation has neither affirmative authorization to withdraw nor affirmative authorization to restrict withdrawal. NAFTA is the best example. Unlike subsequent implementation acts, NAFTA's sunset provision arguably applies only to withdrawal by other parties to the agreement, not to withdrawal by the United States. ${ }^{395}$ In these cases, two questions arise: what power does the President have to withdraw from the agreement, and what power does the President have to terminate the statute implementing such obligations?

The statutory question is easier. Under ordinary principles of constitutional law, supported by INS v. Chadha and Clinton v. New York, the President does not have the power to unilaterally repeal a domestic statute passed by both houses of Congress. Hence, as a practical matter, the President cannot remove his domestic obligation to implement a trade agreement in accordance with implementing legislation (again, barring a constitutional sunset provision).

The international obligations, however, present a harder case, and we can imagine five ways to approach the constitutional question. Which of these five approaches dominates depends on one's preferred substantive and methodological approach to addressing constitutional questions.

First, unilateral withdrawal is permitted, but only if pursuant to an Article II power, such as the recognition power. This was Justice Brennan's position in

authorizing Presidential power to terminate than implementing statutes, like the URAA and NAFTA acts, that do not").

395. See discussion supra note 385. 
Goldwater v. Carter. ${ }^{396}$ In dissent, Brennan argued that the "[a]brogation of the defense treaty with Taiwan was a necessary incident" to the recognition of China, and that this power to recognize or derecognize foreign governments was committed to the President alone. ${ }^{397}$ Brennan cited a variety of cases for support, including Banco Nacional de Cuba v. Sabbatino ${ }^{398}$ and United States v. Pink. ${ }^{399}$ Zivotofsky $v$. Kerry could provide additional support for this view. ${ }^{400}$

Second, unilateral withdrawal is permitted because of historical practice. As Professor Curtis Bradley has shown, historical practice around treaty termination has migrated as a general matter from congressional involvement to presidential control. ${ }^{401}$ Those who use historical practice to interpret the Constitution might therefore consider presidential withdrawal from international obligations to be constitutional.

Third, unilateral withdrawal is permitted due to foreign relations exceptionalism. Supporters of the dicta in Curtiss-Wright or advocates for expansive presidential power under the unspecified "foreign affairs" or "executive" powers might think that withdrawal authority is rooted in these doctrines. ${ }^{402}$

Fourth, unilateral withdrawal is permitted in light of international law background principles. Traditional principles of statutory interpretation hold that Congress legislates with international law as an assumed set of background conditions. ${ }^{403}$ Under the Vienna Convention on the Law of Treaties, heads of state "are considered as representing their State" for purposes of expressing consent to be bound by a treaty. ${ }^{404}$ Accordingly, heads of state can effectively remove such consent under international law. As a result, when Congress passes legislation implementing trade agreements, it understands that international law permits the President to exercise any withdrawal options contained in the agreement. The President therefore has the withdrawal power as a default rule in the absence of any express or implied congressional provision to the contrary. This approach also has the virtue of supporting the existence of sunset clauses in implementing legislation that do not expressly grant withdrawal power to the President with respect to international obligations. The power to withdraw from the international obligations is assumed from the background rules of international law.

396. 444 U.S. 996, 1066 (1979) (Brennan, J., dissenting).

397. Id. at 1007 (Brennan, J., dissenting).

398. 376 U.S. 398 (1964).

399. 315 U.S. 203 (1942).

400. 135 S. Ct. 2076 (2015).

401. Bradley, supra note 10.

402. For a discussion of foreign relations exceptionalism, see Sitaraman \& Wuerth, supra note 7.

403. Cf. Hamdi v. Rumsfeld, 542 U.S. 507, 521 (“[W]e understand Congress' grant of authority for the use of 'necessary and appropriate force' to include the authority to detain for the duration of the relevant conflict, and our understanding is based on longstanding law-of-war principles.") (O'Connor, J.) (plurality opinion).

404. Vienna Convention on the Law of Treaties, May 23, 1969, art. 7.2(a) 1155 U.N.T.S. 331. 
Fifth, unilateral withdrawal is impermissible. Given the unspecified nature of Article II powers, the explicit grant of Article I foreign commerce powers, the early historical practice around termination, and the twin nature of a statute's passage and termination, presidential termination of international trade obligations might be deemed unconstitutional.

Our own view is that presidential powers to terminate the United States' international obligations from a trade agreement, and the consequences of such termination, should depend on ordinary approaches to constitutional and statutory law and interpretation. In particular, the balance of powers between Article I and Article II, Justice Jackson's Youngstown framework, and ordinary principles of interpretation provide a helpful framework for seeing the scope of the President's powers in this arena. In the most challenging cases-the zone of twilight where congressional silence is at issue-decisions will most likely depend on one's preferred approach to interpretation.

In this zone, the confusion about whether trade should be viewed as a foreign affairs issue or a domestic economic issue takes on outsized importance. In Youngstown itself, the Supreme Court was confronted with a fundamentally domestic economic issue: resolving a labor dispute. The case had foreign relations implications only because President Truman claimed that he needed the steel factories to resume work to support the war effort in Korea. ${ }^{405}$ A majority of the Court was ultimately unpersuaded that the foreign affairs implications overrode the domestic economic nature of a labor stoppage..$^{406}$

In our view, the same is true of trade legislation. While the President might well claim authority to terminate trade agreements absent a congressional prohibition on doing so, his international actions cannot overturn domestic statutes, including ones that implement international agreements. Congress passed such implementing legislation pursuant to its Article I powers over the economy, which do not disappear simply because Congress directed the President to regulate based on internationally-agreed standards. Lacking his own constitutional authority over the domestic economy, the President can only regulate pursuant to authority delegated by Congress.

\section{Unorthodox International Lawmaking: Soft Law and Executive Agreements+}

In recent years, scholars have observed that the process of making international agreements has expanded beyond the conventional "triptych" of

405. Youngstown Sheet \& Tube Co. v. Sawyer, 343 U.S. 579, 583 ("The indispensability of steel as a component of substantially all weapons and other war materials led the President to believe that the proposed work stoppage would immediately jeopardize our national defense ....”).

406. Id. at 643-44 ("There are indications that the Constitution did not contemplate that the title Commander-in-Chief of the Army and Navy will constitute [the president] also Commander-in-Chief of the country, its industries and its inhabitants.") (Jackson, J., concurring). 
treaties, congressional-executive agreements, and sole executive agreements. ${ }^{407}$ Rather, a "whole host of less crystalline, more nuanced forms of international legal engagement and cooperation" is now emerging. ${ }^{408}$ These unorthodox forms of international lawmaking share a common feature, namely that neither the Senate nor Congress as a whole has expressly consented to their creation. Commentators analyzing these forms of unorthodox international lawmaking ${ }^{409}$ have largely focused on soft law and executive agreements+ (EA+). They have mostly shied away from assessing whether the constitutionality of these forms of international norm-creation might be different in trade than in other areas of international cooperation, given trade's constitutional pedigree under Article I. ${ }^{410}$ In our view, assessing the constitutionality of these nontraditional forms of international cooperation - in particular, soft law and EA+- requires careful attention to the constitutional allocation of authority over the substantive matters at issue.

Soft law refers to "those [international] nonbinding rules or instruments that interpret or inform our understanding of binding legal rules or represent promises that in turn create expectations about future conduct." 411 One of the best examples of soft law is the Basel Accords. ${ }^{412}$ The Basel Accords seek to harmonize bank regulations and practices internationally, with the most recent Basel III Accords setting capital and liquidity requirements for banks after the 2008 financial crisis. These regulations, in effect, seek to set a level playing field

407. Harold Hongju Koh, Triptych's End: A Better Framework to Evaluate 21st Century International Lawmaking, 126 YALE L.J.F. 338, 349 (2017).

408. Harold Hongju Koh, Legal Adviser, U.S. Dep't of State, Remarks: Twenty-First-Century International Lawmaking, 101 GEO. L.J. 725, 726, 733 (2013); see also Bradley \& Goldsmith, supra note 10; David Kaye, Stealth Multilateralism: U.S. Foreign Policy Without Treaties—or the Senate, 92 FOREIGN AFF. 113, 122 (2013) ("[N]onbinding arrangements may now be the executive branch's preferred way of doing business.").

409. Cf. SinclaiR, supra note 272; Abbe Gluck, Anne Joseph O'Connell \& Rosa Po, Unorthodox Lawmaking, Unorthodox Rulemaking, 115 COLUM. L. REV. 1789 (2015).

410. See, e.g., Duncan B. Hollis \& Joshua J. Newcomer, "Political" Commitments and the Constitution, 49 VA. J. INT'L L. 507 (2009); Jean Galbraith \& David Zaring, Soft Law as Foreign Relations Law, 99 CoRnell L. ReV. 735 (2014); David Bodansky \& Peter Spiro, Executive Agreements +, 49 VAND. J. TRANSNAT'L L. 885 (2016). Bodansky and Spiro carefully note that claims settlement agreements have extremely weak Article II foundations given Congress's foreign commerce power. Id. at 904.

411. Andrew T. Guzman \& Timothy L. Meyer, International Soft Law, 2 J. LEGAL ANALYSIS 171, 174 (2010); see also Galbraith \& Zaring, supra note 410, at 739-40 (defining soft law as "agreements between executive branch actors in two or more countries that do not create legal obligations but which nonetheless contain substantive commitments that the parties are expected to take seriously"). Some authors prefer the term "political commitment" or "pledge" to describe nonbinding commitments by executive branch officials. See Bradley \& Goldsmith, supra note 10, at 1218 ("at bottom a political commitment is like diplomatic speech backed by a personal pledge of the Executive official who made it"); Kal Raustiala, Form and Substance in International Agreements, 99 AM. J. INT'L L. 581, 587 (2005) (using the term "pledge" in preference to the term "soft law").

412. For an overview of the accords, see Basel Regulatory Framework, BOARD OF GOVERNORS OF THE FED. RESERVE SYS., http://www.federalreserve.gov/bankinforeg/basel/default.htm [https://perma.cc/LV86-FLB6]. 
(with reciprocal and equivalent standards) in the international trade of financial services. But the Basel Accords are not treaties (in the constitutional sense) or congressional-executive agreements. Rather, the Federal Reserve negotiates the agreements with foreign regulators and then implements the internationally agreed-upon standards via notice-and-comment rulemaking. ${ }^{413}$ Indeed, the executive branch regularly relies on normal agency authorities that are subject to the Administrative Procedures Act (APA) to give unorthodox international commitments domestic legal effect. ${ }^{414}$ More recently, President Obama entered into the Joint Comprehensive Plan of Action (JCPOA), a nuclear agreement with Iran that was nonbinding internationally and operationalized at the domestic level pursuant to the President's statutory authority to waive economic sanctions. ${ }^{415}$ Note that the imposition or lifting of economic sanctions, although usually framed as a national security issue in the Iran nuclear context, is also a classic case of regulating the terms of foreign trade and commerce.

$\mathrm{EA}+$ "fall somewhere in between" congressional-executive agreements and sole executive agreements. ${ }^{416}$ Unlike sole executive agreements, they are not grounded in the President's Article II powers alone; unlike congressionalexecutive agreements, they are not explicitly authorized by legislation. ${ }^{417}$ Rather, they are "consistent with, and complement, related congressional activity." 118 As an example, consider the Anti-Counterfeiting Trade Agreement (ACTA). In the Pro-IP Act, Congress called on the executive branch to work with foreign countries to increase the enforcement of intellectual property rights. ${ }^{419}$ The Obama Administration relied on this authority to negotiate the ACTA. Congress charged that the executive had no power to "enter into a binding international agreement covering issues delegated by the Constitution to Congress, absent congressional approval. ${ }^{\prime 420}$ In response, the administration argued that while the statutory provision did not authorize the administration to make an ex ante congressional-executive agreement, it did authorize the administration to act internationally to accomplish the statute's charge ${ }^{421}$ Ultimately, the US did not

413. Galbraith \& Zaring, supra note 410 , at 785 .

414. Id.

415. See generally Kenneth Katzman, Iran SAnctions, Cong. Res. Serv. (2018), https://fas.org/sgp/crs/mideast/RS20871.pdf [https://perma.cc/P5F2-842X].

416. Bodansky \& Spiro, supra note 410 , at 887.

417. Id. at 893 .

418. Id. at 887-88.

419. Prioritizing Resources and Organization for Intellectual Property Act of 2008 § 8113(a).

420. Letter from Senator Ron Wyden to President Barack Obama (Oct. 12, 2011), https://www.wyden.senate.gov/download/letter-to-president-obama-asking-why-congress-doesnthave-to-ratify-acta [https://perma.cc/AE68-ZSC6]. See Bodansky \& Spiro, supra note 410, at 908 n.128.

421. See Letter from Harold Koh to Senator Ron Wyden (Mar. 6, 2012), http://infojustice.org/wp-content/uploads/2012/03/84365507-State-Department-Response-to-Wydenon-ACTA.pdf [https://perma.cc/P462-LKWT] [hereinafter Letter from Harold Koh] ("The ACTA was negotiated in response to express Congressional calls for international cooperation to enhance enforcement of intellectual property rights. Congress has passed legislation explicitly calling for the Executive Branch to work with other countries to enhance enforcement of intellectual property 
join ACTA due to domestic political opposition, but it has made a number of other EA+. ${ }^{422}$

Although commentators have analyzed soft law and EA+ in depth, they have not assessed the constitutional authority for these forms of unorthodox international lawmaking from the perspective of a substantive area of law. We think that is a mistake. The strength of the constitutional underpinnings of unorthodox international lawmaking shifts based on the substantive area at issue. For example, in the context of military operations, the President's Article II authorities as commander in chief suggest greater constitutional footing for making unorthodox international agreements. In contrast, the location of trade at the nexus of foreign affairs and domestic economics suggests a more limited purview for unorthodox international agreements, given Congress's express Article I powers to regulate foreign commerce, set tariffs, raise revenues, and take necessary and proper actions to implement those powers.

This distinction is critical for evaluating the executive's authority to conclude such agreements, the process by which agencies should consider such agreements, and the reviewability of such agreements in court. Professors Jean Galbraith and David Zaring, for example, have argued that soft law agreements should be seen through the prism of foreign relations law. In their view, soft law agreements should be afforded significant deference in their creation, implementation, and reviewability because of the deference frequently afforded the President in national security and foreign affairs. ${ }^{423}$ They root this general deference in the "unique figure of the President, who is Commander in Chief of the armed forces, the appointer of ambassadors, and vested with the executive power of the United States - and therefore is the traditional focal point for foreign affairs powers." 424 But while the President undoubtedly has some constitutional powers in foreign affairs, Congress has far more powers in the realm of trade - and its powers are explicitly granted. As a result, we think a better approach would be to evaluate unorthodox international agreements based on the balance of powers afforded the President or Congress under the Constitution. ${ }^{425}$ The degree to which the creation of an agreement or judicial deference is warranted will depend on the underlying constellation of constitutional powers.

Practically speaking, unorthodox international agreements are likely to be implemented by (if not concluded by) administrative agencies. One of the important questions is what authority agencies should have to conclude such

rights... The ACTA helps to answer that legislative call [and] ... is part of a long line of trade agreements that were similarly concluded by successive Administrations."). See Bodansky \& Spiro, supra note 410 , at 909.

422. See Bodansky \& Spiro, supra note 410, at 910.

423. Galbraith \& Zaring, supra note 410 , at 741-42.

424. Id. at 743.

425. See Bradley \& Goldsmith, supra note 10, at 1264 (“[C]ourts are more willing to find implicit statutory authorization in areas in which the President has independent constitutional authority."). 
agreements and what deference they should receive for regulations made in conjunction with those agreements. Galbraith and Zaring argue that in concluding such agreements, agencies should be constrained when Congress has spoken to the issue and forbidden international cooperation, but that when Congress is silent, "the inherent foreign affairs powers located in the executive branch suggest that agencies still should be presumed to have the right to pursue their objectives through soft law." 426

The inquiry seems to us more complicated. In most cases of unorthodox lawmaking, the executive branch can claim some statutory authorization. For instance, in the case of the ACTA, Congress had indeed directed the executive branch to engage with other countries to boost enforcement of intellectual property laws. ${ }^{427}$ But Congress had not expressly authorized, either ex ante or ex post, the conclusion of an international agreement. ${ }^{428}$ If Congress has not delegated such authority to the executive branch and the President does not have an independent Article II power, then any agency action is governed by ordinary administrative law procedures under the Administrative Procedures Act (APA). One of the APA's central purposes is to ensure that administrative action is democratically accountable. ${ }^{429}$ Since administrative agencies do not stand for election, the APA achieves this goal by establishing procedures, such as noticeand-comment rulemaking, that allow interested members of the public to participate in an agency's rulemaking processes. ${ }^{430}$

When an agency undertakes international negotiations upon which it bases a subsequent rulemaking, however, the agency makes a policy determination prior to a fair consideration of the views of domestic interests. ${ }^{431}$ It effectively decides what it will do and renders the notice-and-comment process little more than window dressing. Indeed, this approach privileges the views of other governments over those of ordinary American parties. Where Congress has authorized international negotiations or an international agreement, this privileged access presents no constitutional problems. But where Congress has not authorized this access, the agency arguably acts contrary to the APA's

426. Galbraith \& Zaring, supra note 410 , at 764.

427. See Prioritizing Resources and Organization for Intellectual Property Act of 2008 § 8113(a); Letter from Harold Koh, supra note 421.

428. If Congress has expressly authorized the United States to participate in negotiations or an intergovernmental body, or to conclude an agreement, the President would be acting with the combined powers of both the executive and Congress, and hence his actions would be presumptively constitutional. See Youngstown Sheet \& Tube Co. v. Sawyer, 343 U.S. 579, 635-37 (1952) (Jackson, J., concurring).

429. See generally STEVEN P. CROLEY, REGULATION AND PUBLIC INTERESTS: THE POSSIBILITY OF GOOD REGULATORY GOVERNMENT (2007).

430. Id. at $118-6$.

431. In such cases, we do not think it matters whether the international agreement is binding or nonbinding. In either case, the agency is seeking the outcome reflected in the international agreement, which was reached without accounting for domestic interests through the normal APA process. 
strictures and "in excess of statutory ... authority." ${ }^{32}$ Given the primacy of Congress over foreign commerce and economic concerns generally, courts reviewing regulations based on international standards should carefully scrutinize agency claims of implicit consent or atmospheric acquiescence to the use of unorthodox international agreements as an input into the domestic regulatory process. ${ }^{433}$

Relatedly, administrative agencies should not be given leeway to evade traditional administrative law requirements under the APA. For example, agencies are required to respond to commentators during the notice-andcomment process, or they risk a court finding their final rule arbitrary and capricious because the agency failed to engage in reasoned decision-making. ${ }^{434}$ During the course of the first Basel Accords, the Federal Reserve explained away some commenters' opinions because they "would be inconsistent with the framework agreed upon by the G-10 countries." ${ }^{35}$ This justification seems problematic to us. If Congress did not authorize international negotiations, then the Federal Reserve should not be able to use the international negotiations as a shield in subsequent rulemaking. To do so further elevates the importance of foreign governments' concerns over the concerns that Congress has directed the agency to consider in the APA. In this case, the Federal Reserve should have had to follow all of the ordinary administrative law requirements and principles that Congress and the courts have established for rulemaking-including providing a reasoned explanation for its actions that responds meaningfully on the merits to commenters. If an agency cannot offer a justification for internationally agreed-upon standards that is meritorious in relation to the principles by which Congress has directed it to regulate, it should not be able to incorporate those standards into domestic law simply because other governments favor them.

\section{E. Trade Federalism}

The President's control of trade policy also has important implications for the allocation and exercise of economic power between the federal government and the States. We refer to this relationship (insofar as it implicates international trade) as "trade federalism." Like other international agreements, trade agreements present a challenge to the US model of vertically separated powers.

432. Administrative Procedure Act, 5 U.S.C. § 706(2)(C) (2017).

433. It is worth noting that the Supreme Court has not uniformly found in favor of the executive branch on claims of atmospheric acquiescence. While proponents of unorthodox international agreements often cite Dames \& Moore v. Regan, 453 U.S. 654 (1981), as an example of judicial acceptance of an EA+ that even the Court recognized was not explicitly authorized in legislation, in both Youngstown, 343 U.S. 579 (1952), and FDA v. Brown and Williamson, 529 U.S. 120 (2000), the Supreme Court found that legislative atmosphere did not authorize executive branch action.

434. See Baltimore Gas \& Electric Co. v. United States, 817 F.2d 108, 115-16 (D.C. Cir. 1987) (finding that, while agencies need not respond to all comments, the "arbitrary and capricious" standard requires them to respond to significant challenges to the reasonableness of the proposed rule).

435. See Galbraith \& Zaring, supra note 410 , at 760 . 
Under the international law of state responsibility, the United States is strictly liable for violations committed by state and local governments, even if the federal government is constitutionally prohibited from preempting the state action. ${ }^{436}$ This liability creates tensions between the President and Congress over how to ensure the compatibility of US law, including state and local law, with international trade agreements. In these situations, the President often supports the compliance with trade agreements, while Congress often stands up for state and local rules.

The challenge of trade federalism goes beyond compliance with international legal obligations. Under our constitutional system, trade federalism operates in an uncomfortable limbo. The foreign affairs paradigm suggests that international trade should operate under principles of foreign relations exceptionalism, in which the political branches determine policy, and local and state interests give way to national interests. The domestic economics paradigm recognizes the important role that Congress plays in making economic policy for an extended and diverse republic. What makes trade federalism so complex and scrambled is that Congress makes policy at the national level in part for reasons of uniformity, and in the foreign relations context, the Supreme Court has recognized the traditional importance of state and local governments under our constitutional system. ${ }^{437}$

These tensions are particularly important in the current historical moment. Today, states and cities are increasingly regulating matters of international concern. For example, cities have come together to form their own climate change pact, ${ }^{438}$ while states like California (which by itself would be one of the ten largest national economies in the world) have begun aggressively regulating greenhouse gases. ${ }^{439}$ States and localities have also been active in debates about immigration, pronouncing themselves "sanctuaries" for undocumented immigrants. ${ }^{440}$ Other states, such as Massachusetts, have passed laws targeting

436. Int'l Law Comm'n, Draft Articles on Responsibility of States for Internationally Wrongful Acts, U.N. Doc. A/56/10, at 36, 40-41 (2001) [hereinafter "Draft Articles on State Responsibility"]; see also Timothy Meyer, Local Liability in International Economic Law, 95 N.C. L. REV. 261, 272 (2017) [hereinafter "Meyer, Local Liability"] (describing the Draft Articles rule as one of "strict vicarious liability" for subnational government action).

437. See Sitaraman \& Wuerth, Normalization, supra note 7, at 1903-30.

438. GLOBAL COVENANT OF MAYORS FOR CliMATE AND ENERGY, https://www.globalcovenantofmayors.org [https://perma.cc/UUK5-JTBR]; see also Aamer Madhani, Forget Paris: U.S. Mayors Sign Pact to Carry Out Paris Agreement, USA TODAY (Dec. 4, 2017), https://www.usatoday.com/story/news/2017/12/04/u-s-mayors-sign-pact-track-progress-parisagreement/920305001 [https://perma.cc/SY3H-PS6M] (describing the Chicago Charter, an agreement among U.S. mayors to implement the Paris Agreement on climate change's emissions reduction goals).

439. California plans to reduce greenhouse gas emissions $40 \%$ by 2030, U.S. ENERGY INFO. AGENCY, https://www.eia.gov/todayinenergy/detail.php?id=34792 [https://perma.cc/5NTW-AZJY].

440. Jasmine C. Lee, Rudy Omri \& Julia Preston, What are Sanctuary Cities?, N.Y. TIMES (Feb. 6, 2017), https://www.nytimes.com/interactive/2016/09/02/us/sanctuary-cities.html [https://perma.cc/F9PM-YWCU]. 
human rights abuses overseas. ${ }^{441}$ Given the increased prominence of state and local governments in tackling international problems, the potential for the President's trade agenda to severely impair trade federalism raises serious concerns.

As discussed in Part I, tariffs were the principal concern of trade negotiations for decades. Setting tariff rates, and controlling foreign commerce more generally, are plenary powers of Congress. ${ }^{442}$ Consequently, trade negotiations that focused on tariffs and import/export procedures raised few federalism issues. Even the GATT, however, imposed rules that applied behind the border. Chief among these rules was the national treatment rule, which prohibited a GATT party from treating foreign products less favorably than like domestic products. ${ }^{443}$ The national treatment rule prohibited a wide variety of discriminatory policies that state and local governments might have enacted, such as local content requirements. ${ }^{444}$ Despite the formal application of the GATT to subnational policies, however, subnational government action was not a primary focus of the GATT parties.

As the GATT parties shifted their attention from tariffs to nontariff barriers, however, the policies of subnational governments became more and more important. The WTO Agreements have created a host of new rules limiting how governments regulate behind the border, including rules governing laws that affect public health, food safety, product safety, and environmental protection. Such laws can be considered nontariff barriers to trade when they have the effect of stymying the cross-border flow of goods, services or capital. Most notably, the Technical Barriers to Trade Agreement applies to regulations governing product standards, ${ }^{445}$ and the Sanitary and Phytosanitary Agreement applies to, inter alia, food safety regulations. ${ }^{446}$ Additionally, the Agreement on Subsidies and Countervailing Measures imposes limits on the kinds of subsidies governments can offer, ${ }^{447}$ and the General Agreement on Trade in Services imposes limits on government regulation of service providers. ${ }^{448}$

441. See Crosby v. Nat. Foreign Trade Council, 530 U.S. 363 (2000).

442. U.S. CONST. art. I, $\$ 8$.

443. GATT, supra note 136, art. III.

444. "Local content requirements are laws, regulations, or governmental measures that condition a benefit on the use of a certain percentage of inputs from the local jurisdiction." Timothy Meyer, How Local Discrimination Can Promote Global Public Goods, 95 Boston U. L. ReV. 1937, 1945 (2015) [hereinafter "Meyer, Local Discrimination"]; see also Holger P. Hestermeyer \& Laura Nielsen, The Legality of Local Content Measures Under WTO Law, 48 J. WORLD TRADE 553, 554 (2014).

445. See generally Agreement on Technical Barriers to Trade, Apr. 15, 1994, Marrakesh Agreement Establishing the World Trade Organization, Annex 1A, 1868 U.N.T.S. 120.

446. See generally Agreement on the Application of Sanitary and Phytosanitary Measures, Apr. 15, 1994, Marrakesh Agreement Establishing the World Trade Organization, Annex 1A, 1867 U.N.T.S. 493.

447. See generally Agreement on Subsidies and Countervailing Measures, supra note 287.

448. See generally GATS, supra note 172 . 
Unlike tariffs and other border measures, these trade rules governing nontariff barriers implicate longstanding, core powers of state and local governments. State and local governments regularly pass product and food safety rules, license service providers, and regulate to protect the environment. Our constitutional system values the power and independence of state and local governments. But the default rule under the international law of state responsibility is that the national government is strictly liable for its own actions, as well as for the actions of any subnational governments. ${ }^{449}$ Indeed, the nation remains liable even if, as a political or constitutional matter, the national government cannot control the actions of the subnational government. ${ }^{450}$

The combination of international law's rules on liability for subnational governments and trade law's expansion into nontariff barriers that implicate state police powers creates a situation in which state and local governments can open the United States up to retaliation from other countries for breaching trade agreements. Indeed, state rules have figured prominently in a number of WTO disputes. For instance, the EU successfully challenged subsidies that the State of Washington provided to Boeing under the WTO's Subsidies and Countervailing Agreement. ${ }^{451}$ Additionally, a WTO panel ruled that the United States unlawfully discriminated against Antigua because US laws ban online gambling with companies based outside of the United States, even though state laws in virtually every state permit gambling of some kind with businesses located within the state. ${ }^{452}$ The trend towards applying international trade agreements to state and local action holds outside of the WTO context as well. Over 40 percent of the investor-state claims brought under NAFTA, and a quarter of such claims brought against the United States, challenge state and local action. ${ }^{453}$

The potential for liability highlights a tension between the roles that Congress and the executive play. The President, who must defend the United States in claims brought against it and who is often thought to prefer to liberalize trade in any event, may wish to preempt the unlawful state or local action to avoid retaliation against the United States. Indeed, Congress has given the President, but not private parties, the power to sue state and local governments

449. Draft Articles on State Responsibility, supra note 436, at 8440-41; see also Meyer, supra note 436, at 272 (describing the Draft Articles rule as one of "strict vicarious liability" for subnational government action).

450. Draft Articles on State Responsibility, supra note 436, at 36.

451. Appellate Body Report, United States-Measures Affecting Trade in Large Civil Aircraft(Second Complaint), II 1350, WTO Doc. WT/DS353/AB/R (adopted Mar. 23, 2012) (holding that subsidies granted to Boeing by the State of Washington and the City of Wichita, Kansas, violated the WTO's Agreement on Subsidies and Countervailing Measures).

452. See Appellate Body Report, United States-Measures Affecting the Cross-Border Supply of Gambling and Betting Services, II 5, WTO Doc. WT/DS285/AB/R (adopted Apr. 7, 2005) (finding that US and local laws prohibiting internet gambling while permitting in-person gambling violate the General Agreement on Trade in Services).

453. Meyer, Local Liability, supra note 436, at 277. 
to seek a judgment that a subnational measure violates the WTO agreements. ${ }^{454}$ However, as far as we are aware the United States has never brought such an action.

This puzzling lack of challenges is perhaps explained by congressional resistance. To be sure, the URAA requires that the President consult with the States to try to make state law uniform with the United States' trade commitments. ${ }^{455}$ The URAA also requires the US Trade Representative to establish an office to facilitate this consultation process. ${ }^{456}$ The US Trade Representative must consult with the States whenever a state law is challenged in a WTO case and must allow the State an opportunity to help formulate the United States' position. ${ }^{457}$ The US Trade Representative is also required to report to Congress both any legal suits the United States takes to preempt WTOinconsistent state laws ${ }^{458}$ and any WTO cases brought by other members challenging state laws as WTO-inconsistent. ${ }^{459}$

But what Congress has not done is give the executive the authority to preempt WTO-inconsistent state laws through regulation. Federal regulations do preempt inconsistent state laws. Congress therefore could have given the President the power to harmonize state law with WTO obligations through administrative rulemaking. But Congress instead chose to impose consultation requirements on the President and delegate the authority to make a determination of WTO-inconsistency to the courts. This suggests that Congress might have been concerned with preserving the role of the States. Indeed, even if the United States did initiate a suit to preempt state laws, the URAA makes clear both that the United States bears the burden of proving the inconsistency and that the courts should accord no deference to the WTO's own decision regarding the state law. ${ }^{460}$ These provisions further suggest that Congress is acting to protect the interests of the States. ${ }^{461}$

The resulting system of trade federalism can be justified neither by the foreign affairs paradigm nor by the domestic economics paradigm. State and local governments have limited control over their own borders and may behave

454. $\quad$ URAA § 102(b)(2), 19 U.S.C. § 3501 (2017) ("No State law, or the application of such a State law, may be declared invalid as to any person or circumstance on the ground that the provision or application is inconsistent with any of the Uruguay Round Agreements, except in an action brought by the United States for the purpose of declaring such law or application invalid.”).

455. Id. § 102(b)(1)(A).

456. Id. § 102(b)(1)(B).

457. Id. $\S 102(\mathrm{~b})(1)(\mathrm{C})$

458. Id. § 102(b)(2)(C).

459. Id. § 124 .

460. Id. § 102(b)(2)(B)(i)-(ii) (" $[\mathrm{A}]$ report of a dispute settlement panel or the Appellate Body convened under the Dispute Settlement Understanding regarding the State law, or the law of any political subdivision thereof, shall not be considered as binding or otherwise accorded deference.").

461. Cf. Wechsler, supra note 266. 
in a protectionist fashion behind their borders. ${ }^{462}$ That Congress would defend the interests of the States protecting their interests is logical. Members of Congress are, after all, elected at the state or local level. ${ }^{463}$ But Congress's position in the URAA represents an awkward compromise between state and national interests. Congress has not required that the executive negotiate trade agreements in a way that minimizes the interference with common state law schemes. Nor has Congress itself taken steps to determine which state laws should be preempted. Instead, Congress has left the President a largely free hand to negotiate trade agreements that increasingly implicate core state and local government powers - but has given the President little ability to address the results of such agreements. ${ }^{464}$

As a result, our trade federalism is at best in disarray and at worst at risk of collapsing into trade nationalism. Claims challenging state and local action, including in areas in which those governments are attempting to address other matters of international concern, can be expected to rise. In 2016, for instance, India initiated a case against the United States challenging a number of state and local measures that provide financial support for renewable energy. ${ }^{465}$ The dysfunction that this state of affairs creates harms both economic and foreign policy considerations. On the one hand, the executive branch cannot tailor international trade law to the wide variation of local concerns found throughout the United States. On the other hand, state and local governments lack incentives to reconcile their economic regulation with foreign policy. In sum, Congress's embrace of the foreign affairs paradigm and its concomitant delegation of powers to the executive to negotiate trade agreements with nontariff barriers pose an ongoing and increasingly significant threat to trade federalism.

\section{CONCLUSION}

Trade and security are the two policies most central to every nation's wellbeing and most critical to every government's functioning. The United States replaced the Articles of Confederation with the Constitution in large part to give the nation control over trade policy. The world's other great federation, the

462. Meyer, Local Discrimination, supra note 444, at 1942 ("[D]iscriminatory conditions are more likely at smaller scales of government.").

463. See Wechsler, supra note 266, at 544-47.

464. In recent free trade agreements, such as the TPP, the United States responded to state and local interests by inserting some limited exemptions for state and local programs. These exemptionssimilar to so-called "federalism declarations" attached to other treaties to make clear that the United States does not accept international responsibility for the actions of its state and local governmentsapply only to the nondiscrimination rules in the services and investment chapters of the agreements. As such, they are fairly narrow in scope. Moreover, such clauses cannot easily be introduced to the WTO, where existing agreements are difficult to amend, and other countries would have little reason to agree to reduce the United States' incentives to pressure its state to comply with trade rules. See generally Meyer, Local Liability, supra note 436.

465. Request for Consultations, United States-Certain Measures Relating to the Renewable Energy Sector, WTO Doc. WT/DS510/1 (Sept. 9, 2016). 
European Union, used trade integration to rebuild itself after two catastrophic world wars.

The twenty-first century has been dominated by security considerations since the attacks of September 11 turned the Bush presidency into a wartime presidency. The 2016 presidential election marked a turning point. As both the Republican and Democratic parties pursue policies aimed at addressing voters' economic insecurity, trade policy is once again taking center stage. At this moment, understanding how our trade constitution came to be is critical to understanding how our trade policy can and will be made going forward. The country's rightful concern about a host of global challenges - climate change, rogue regimes like North Korea, the rise of China as a global power-make it tempting to revert to a trade policy dominated by foreign policy considerations.

Yet as President Obama's ill-fated efforts to negotiate the TPP and justify it on foreign policy grounds shows, foreign policy considerations simply cannot carry the weight of a domestic economic policy that so many Americans of both parties feel no longer benefits them. Trade liberalization for its own sake-the utilitarian idea that we should maximize aggregate national welfare through our trade policy without concern for the distribution of the gains from that policyis an idea whose time is past. Going forward, concerns about economic opportunity, equality, and the distribution of the gains from our trade policies will dominate our politics. How those concerns will shape that policy remains to be seen. Protectionist policies like punitive tariffs and subsidies (for manufacturers and displaced labor) redistribute wealth, although they have very different trade implications.

A trade policy dominated by the President is unable to deal comprehensively with domestic concerns. Only if Congress participates as a full constitutional partner will the United States have a sustainable trade liberalization policy that enjoys broad public support. Nothing legally or functionally prevents Congress from reasserting its constitutional role. Whether it will do so remains to be seen. 